\title{
MICROBUBBLE FERMENTATION of RECOMBINANT Pichia pastoris for HUMAN SERUM ALBUMIN PRODUCTION
}

\author{
Wei Zhang \\ Thesis submitted to the Faculty of the \\ Virginia Polytechnic Institute and State University \\ in partial fulfillment of the requirement for the degree of \\ Master of Science \\ in
}

Biological Systems Engineering

Foster A. Agblevor, Chairman

John S. Cundiff

Chenming Zhang

May 1, 2003

Blacksburg, Virginia

Keyword: microbubble dispersion, oxygen transfer, Pichia pastoris fermentation, human serum albumin 


\title{
MICROBUBBLE FERMENTATION of RECOMBINANT Pichia pastoris for HUMAN SERUM ALBUMIN PRODUCTION
}

\author{
by \\ Wei Zhang \\ Dr. Foster A. Agblevor, Chairman \\ Biological Systems Engineering
}

(ABSTRACT)

The high cell density fermentation of recombinant Pichia pastoris for human serum albumin (HSA) production is a high oxygen demand process. The oxygen demand is usually met by increased agitation rate and use of oxygen-enriched air. Microbubble fermentation however can supply adequate oxygen to the microorganisms at relatively low agitation rates because of improved mass transfer of the microbubbles used for the sparging. Conventionally sparged fermentations were conducted for the production of HSA using P. pastoris at agitation rates of 350, 500, and $750 \mathrm{rpm}$, and were compared to MBD sparged fermentation at 150, 350, and 500 rpm agitation rates. The MBD improved the volumetric oxygen transfer coefficient $\left(k_{L} a\right)$ and subsequently increased the cell mass and protein production compared to conventional fermentation.

Cell production in MBD fermentation at $350 \mathrm{rpm}$ was 4.6 times higher than that in the conventional fermentation at $350 \mathrm{rpm}$, but similar to that in the conventional $750 \mathrm{rpm}$. Maximum cell mass productivity in the conventional $350 \mathrm{rpm}$ was only $0.37 \mathrm{~g} /(\mathrm{L} \bullet \mathrm{h})$, while the maximum value in MBD $350 \mathrm{rpm}$ was $2.0 \mathrm{~g} /(\mathrm{L} \cdot \mathrm{h})$, which was similar to $2.2 \mathrm{~g} /(\mathrm{L} \cdot \mathrm{h})$ in the conventional $750 \mathrm{rpm}$. Biomass yield on glycerol $Y_{S}$ (g cell/g glycerol) was $0.334 \mathrm{~g} / \mathrm{g}$ in the conventional $350 \mathrm{rpm}, 0.431 \mathrm{~g} / \mathrm{g}$ in MBD $350 \mathrm{rpm}$ and $0.438 \mathrm{~g} / \mathrm{g}$ in the conventional $750 \mathrm{rpm}$. Protein production in MBD $350 \mathrm{rpm}$ was 7.3 times higher than that in the conventional $350 \mathrm{rpm}$, but similar to that in the conventional $750 \mathrm{rpm}$. Maximum protein productivity in the conventional $350 \mathrm{rpm}$ was $0.37 \mathrm{mg} /(\mathrm{L} \bullet \mathrm{h}), 2.8 \mathrm{mg} /(\mathrm{L} \bullet \mathrm{h})$ in MBD $350 \mathrm{rpm}$, and $3.3 \mathrm{mg} /(\mathrm{L} \bullet \mathrm{h})$ in the conventional $750 \mathrm{rpm}$. Protein yield on methanol Yp (mg protein / g methanol) was $1.57 \mathrm{mg} / \mathrm{g}$ 
in the conventional $350 \mathrm{rpm}, 5.02 \mathrm{mg} / \mathrm{g}$ in MBD $350 \mathrm{rpm}$, and $5.21 \mathrm{mg} / \mathrm{g}$ in the conventional $750 \mathrm{rpm}$.

The volumetric oxygen transfer coefficient $k_{L} a$ was $1011.9 \mathrm{~h}^{-1}$ in MBD $350 \mathrm{rpm}$, which was 6.1 times higher than that in the conventional $350 \mathrm{rpm}\left(164.9 \mathrm{~h}^{-1}\right)$ but was similar to the conventional $750 \mathrm{rpm}\left(1098 \mathrm{~h}^{-1}\right)$. Therefore, MBD fermentation results at low agitation of 350 rpm were similar to those in the conventional fermentation at high agitation of $750 \mathrm{rpm}$. There was considerable improvement in oxygen transfer to the microorganism using MBD sparging relative to the conventional sparging.

Conventional fermentations were conducted both in a Biostat Q fermenter (small) at 500 rpm, $750 \mathrm{rpm}$, and $1000 \mathrm{rpm}$, and in a Bioflo III fermenter (large) at $350 \mathrm{rpm}, 500 \mathrm{rpm}$, and 750 $\mathrm{rpm}$. At the same agitation rate of $500 \mathrm{rpm}$, cell production in the large reactor was 3.8 times higher than that in the small one, and no detectable protein was produced in the small reactor at $500 \mathrm{rpm}$. At the same agitation rate of $750 \mathrm{rpm}$, both cell production and protein production in the large reactor were 4.6 times higher than the small reactor. Thus, the Bioflo III fermenter showed higher oxygen transfer efficiency than the Biostat Q fermenter, because of the more efficient aeration design of the Bioflo III fermenter. 


\section{ACKNOWLEDGMENTS}

I wish to express my sincere gratitude and respect to my advisor Dr. Foster A. Agblevor for his ideas, patience, and advice throughout my Master's program. I am thankful for his willingness to take the time to make suggestions and help me achieve my goals. His support, guidance, and encouragement were most appreciated.

Thanks are expressed to the members of my committee, Dr. John S. Cundiff and Dr. Chenming Zhang. Thanks are also expressed to the Head of BSE Department, Dr. John V. Perumpral and BSE Graduate Committee Chairman, Dr. Saied Mostaghimi. I would like to thank all of the graduate students and technicians that assisted in this research. In particular, I am grateful to Aubrey Murden and Kim Harich for their assistance with the laboratory work and analysis.

Finally, I would especially like to thank my parents for their love, support, and encouragement that they have given me throughout my academic career. 


\section{TABLE OF CONTENTS}

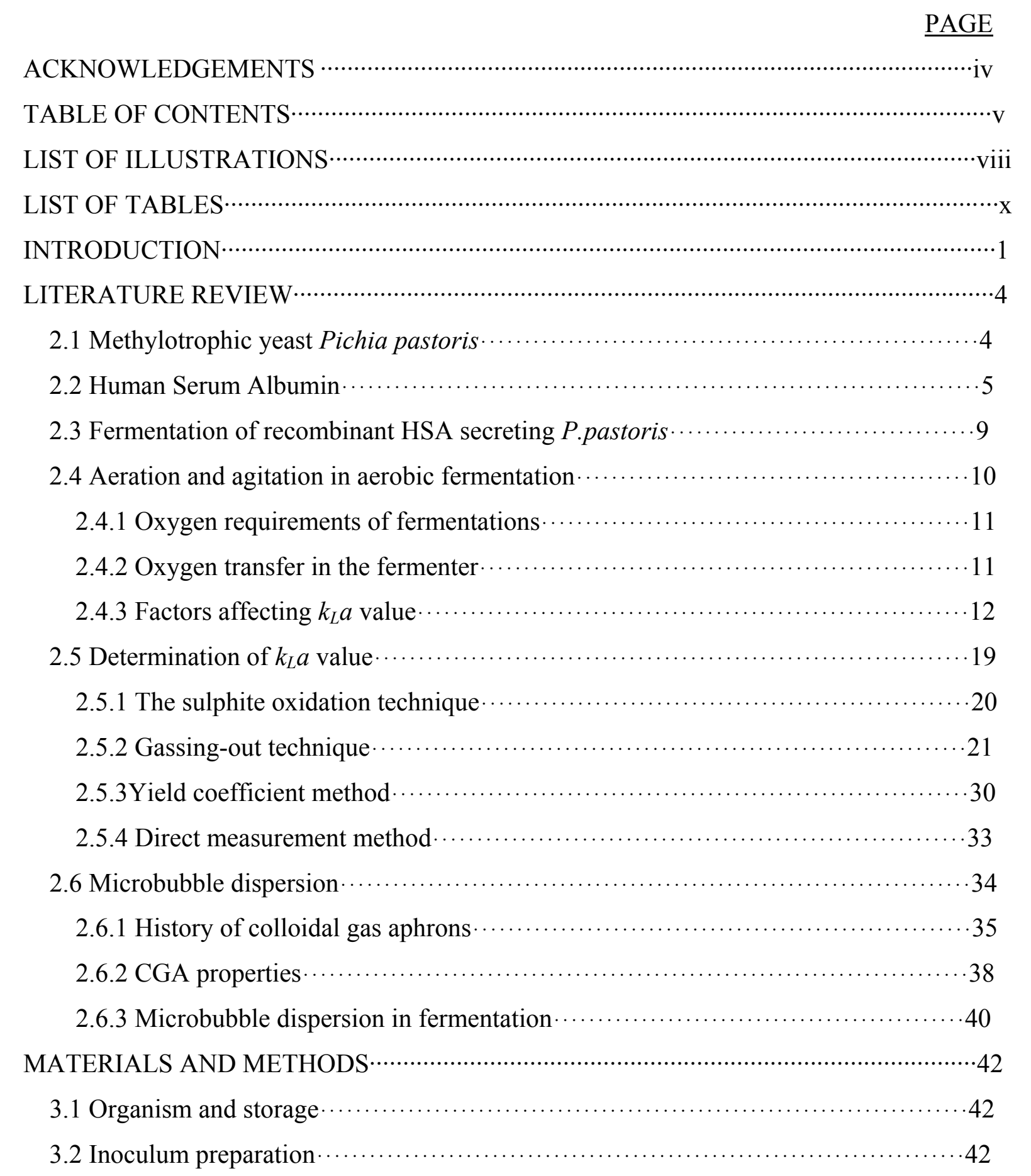




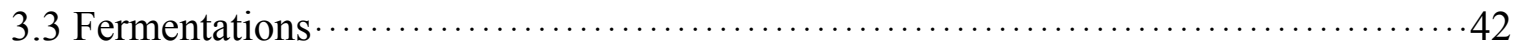

3.3.1 750ml fermentation with conventionally sparging $\ldots \ldots \ldots \ldots \ldots \ldots \ldots \ldots \ldots, \ldots 2$

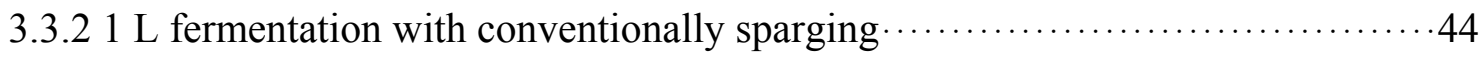

3.3.3 $1 \mathrm{~L}$ fermentation with microbubble dispersion sparging $\ldots \ldots \ldots \ldots \ldots \ldots \ldots \ldots, \ldots+\ldots \ldots$

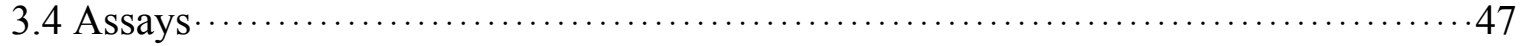

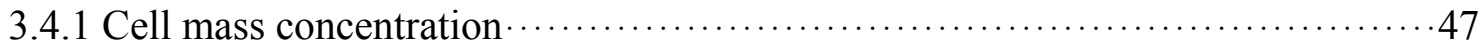

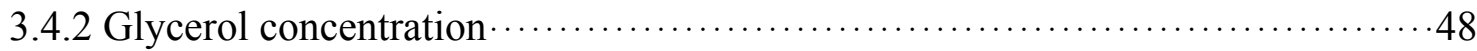

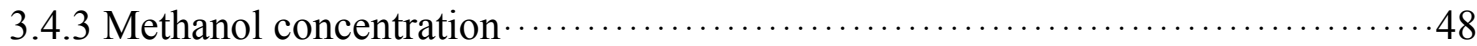

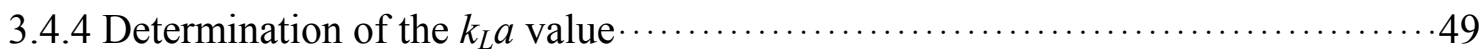

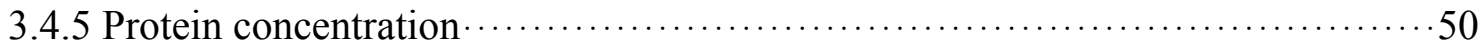

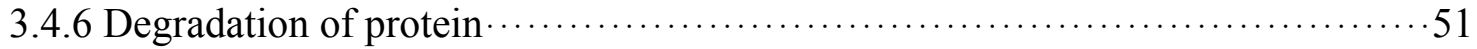

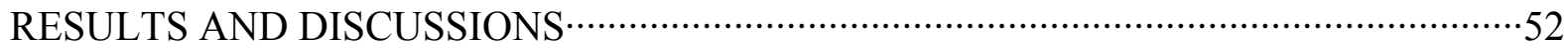

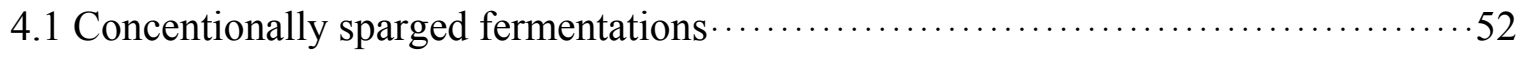

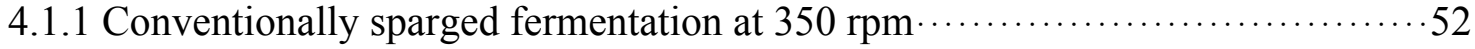

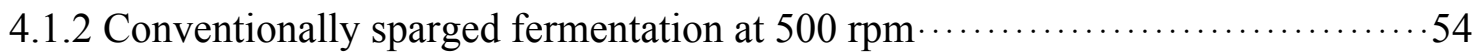

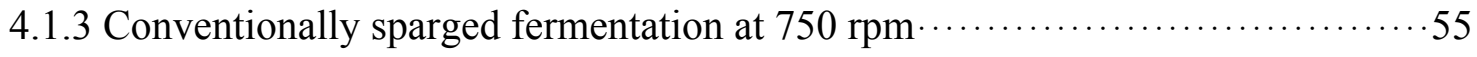

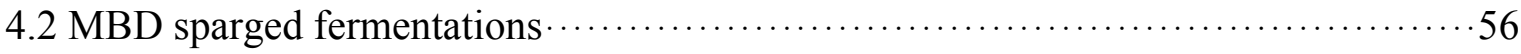

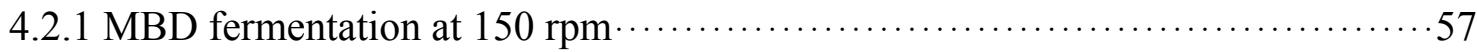

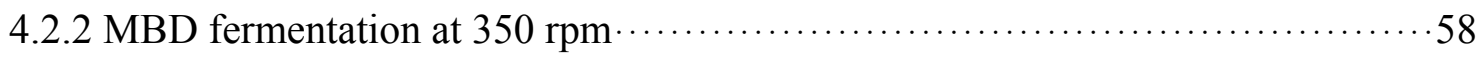

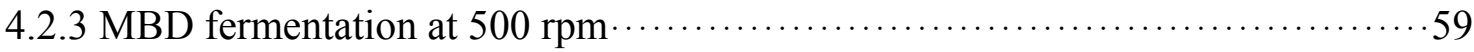

4.3 Comparison between conventionally and MBD sparged systems $\cdots \ldots \ldots \ldots \ldots \ldots \ldots 6,61$

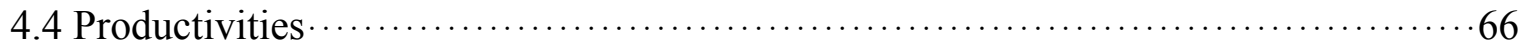

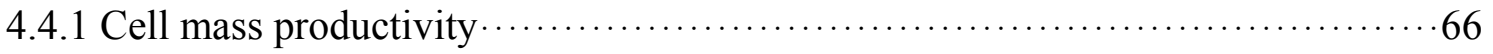

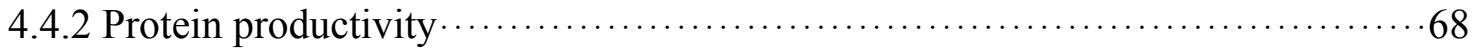

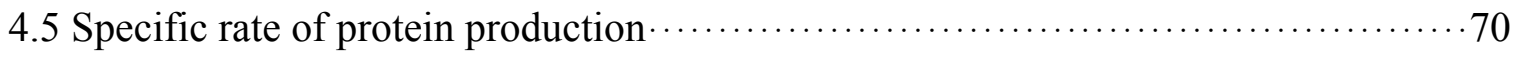

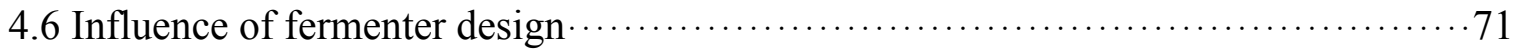

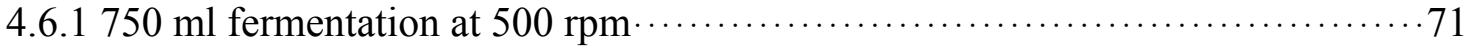

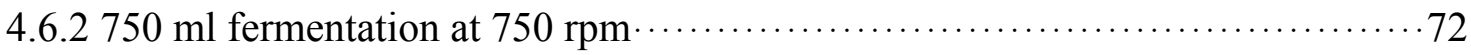

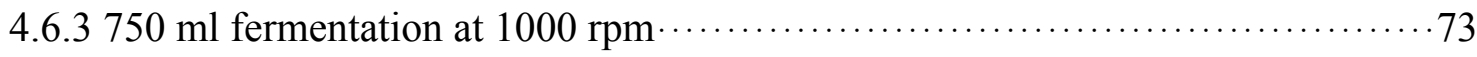

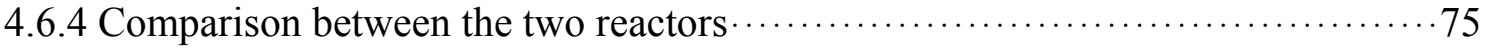

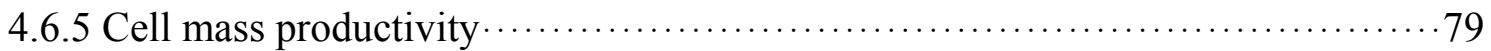

TABLE OF CONTENTS vi 


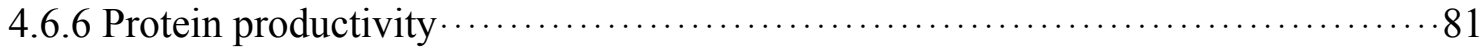

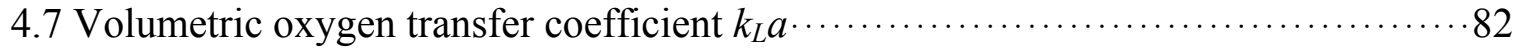

4.7.1 Comparison of $k_{L} a$ value between two reactors $\ldots \ldots \ldots \ldots \ldots \ldots \ldots \ldots \ldots \ldots \ldots \ldots$

4.7.2 Comparison of $k_{L} a$ value between MBD and conventional systems $\cdots \ldots \ldots \ldots \ldots 85$

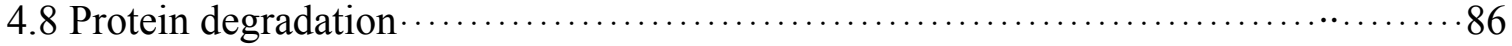

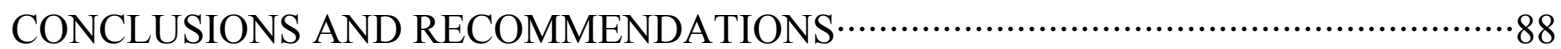

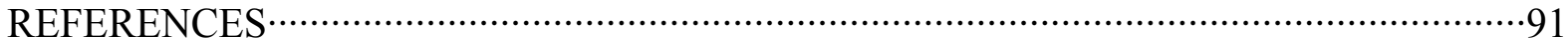

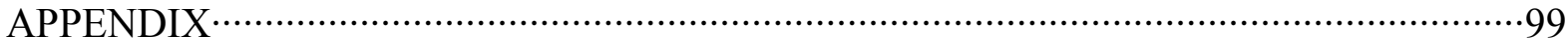

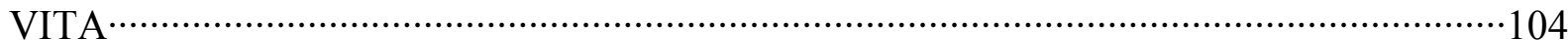

TABLE OF CONTENTS vii 


\section{LIST OF ILLUSTRATIONS}

$\underline{\text { PAGE }}$

Figure 2.1 Gene replacement event at the $A O X 1$ locus $\ldots \ldots \ldots \ldots \ldots \ldots \ldots \ldots \ldots \ldots \ldots \ldots, \ldots$

Figure 2.2 The effect of air-flow rate on the $k_{L} a$ of an agitated aerated vessel $\ldots \ldots \ldots \ldots \ldots \ldots$

Figure 2.3 Different patterns of gas bubble dispersion in a stirred-tank reactor $\cdots \ldots \ldots \ldots \ldots 18$

Figure 2.4 The increase in dissolved oxygen concentration of a solution $\cdots \ldots \ldots \ldots \ldots \ldots \ldots 22$ over a period of aeration

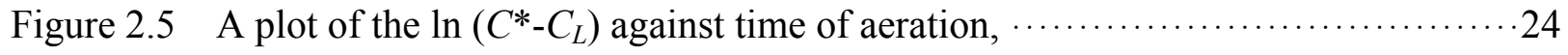
the slope of which equals $-k_{L} a$

Figure 2.6 Dynamic gassing out for the determination of $k_{L} a$ values $\ldots \ldots \ldots \ldots \ldots \ldots \ldots \ldots \ldots \ldots \ldots \ldots$ Aeration was terminated at point $\mathrm{A}$ and recommenced at point $\mathrm{B}$

Figure 2.7 The dynamic method for determinatin of $k_{L} a$ values $\ldots \ldots \ldots \ldots \ldots \ldots \ldots \ldots \ldots \ldots \ldots \ldots \ldots \ldots$

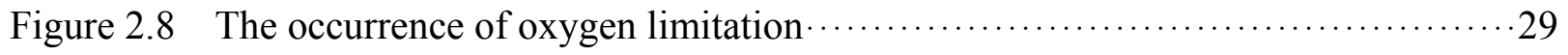
during the dynamic gassing out of a fermentation

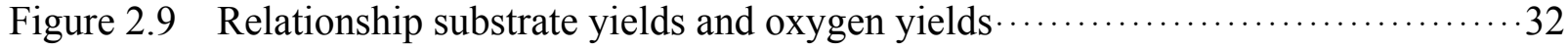
for different microorganisms grown on different substrates

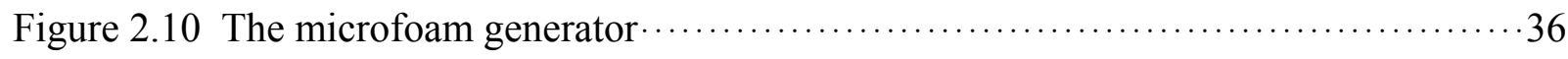

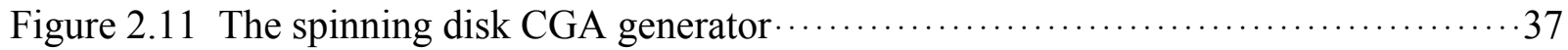

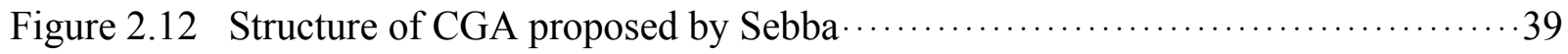

Figure $3.1 \quad 1$ liter fermentation with microbubble dispersion unit $\ldots \ldots \ldots \ldots \ldots \ldots \ldots \ldots \ldots$

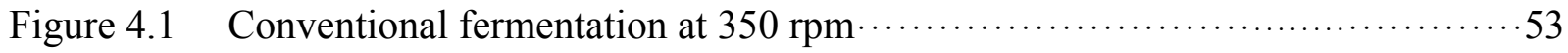

Figure 4.2 Conventionally sparged fermentation at $500 \mathrm{rpm} \ldots \ldots \ldots \ldots \ldots \ldots \ldots \ldots \ldots \ldots \ldots \ldots \ldots \ldots \ldots$

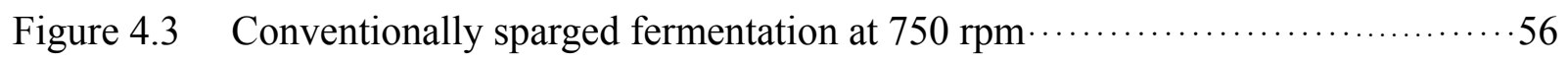

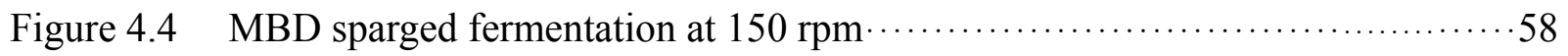

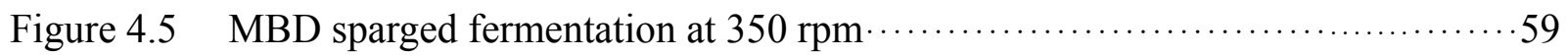

LIST OF ILLUSTRATIONS Viii 


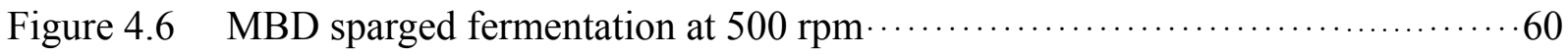

Figure 4.7 Comparison of cell growth between MBD and conventional systems $\cdots \cdots \cdots \cdots \cdot 62$

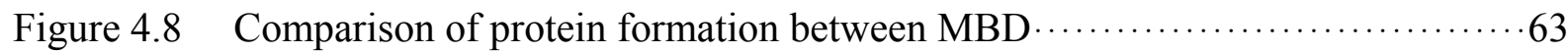
and conventional systems

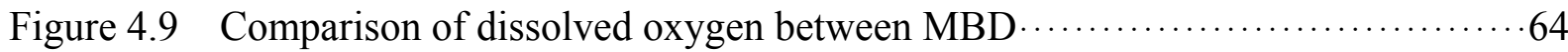
and conventional systems

Figure 4.10 Cell mass productivity in MBD and conventionally sparged systems $\cdots \cdots \cdots \cdots 67$

Figure 4.11 Protein productivity in MBD and conventionally sparged systems $\cdots \ldots \ldots \ldots \ldots 69$

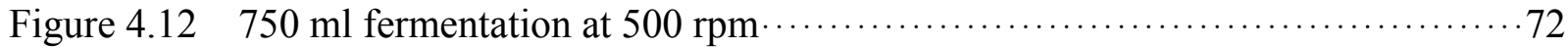

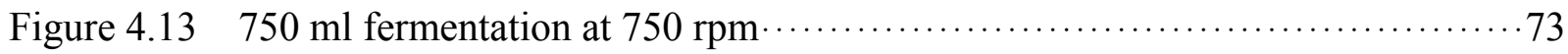

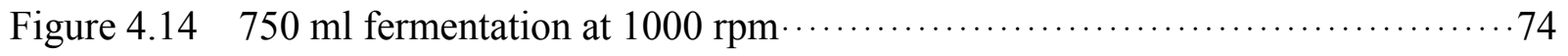

Figure 4.15 Comparison of cell growth pattern between two reactors $\cdots \ldots \ldots \ldots \ldots \ldots \ldots \ldots \ldots$

Figure 4.16 Comparison of protein formation pattern between two reactors $\cdots \cdots \cdots \ldots \ldots \ldots . \cdots 77$

Figure 4.17 Comparison of dissolved oxygen pattern between two reactors …............78

Figure 4.18 Cell mass productivity in conventional fermentation $\cdots \ldots \ldots \ldots \ldots \ldots \ldots \ldots \ldots \ldots$

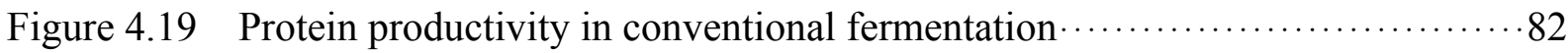

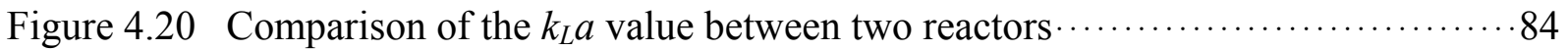

Figure 4.21 Comparison of $k_{L} a$ value between MBD and conventional systems $\cdots \ldots \ldots \ldots . \cdots 85$

Figure 4.22 SDS-PAGE of different stages of fermentation broth samples ….............8 87 in both MBD and conventional systems

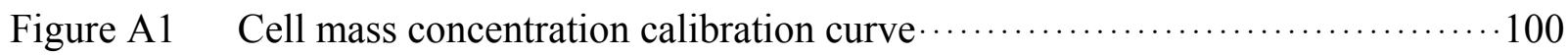

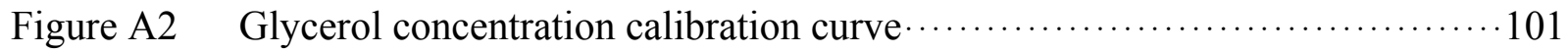

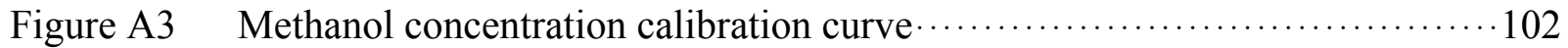

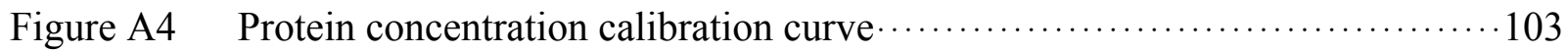

LIST OF ILLUSTRATIONS $\quad$ ix 


\section{LIST OF TABLES}

$\underline{\text { PAGE }}$

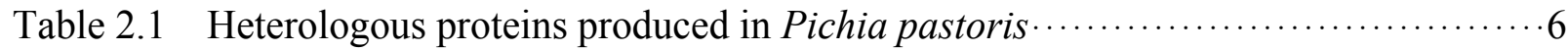

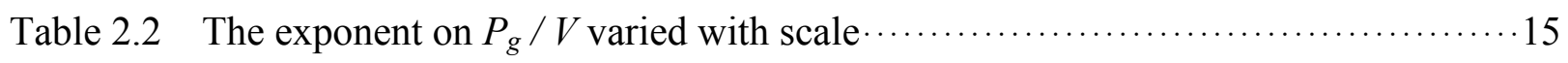

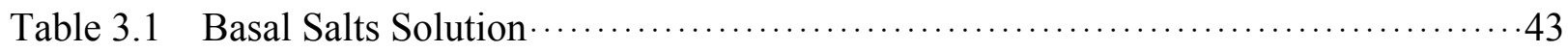

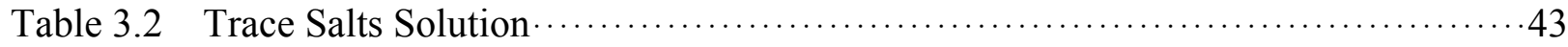

Table 4.1 Cell mass concentration, protein concentration, substrate yield $\cdots \ldots \ldots \ldots \ldots \ldots \ldots \ldots 6$ and product yield comparison between MBD and air sparging systems

Table 4.2 Cell mass concentration, protein concentration, substrate yield .79 and product yield comparison between two fermenters

Table A1 Cell mass concentration calibration data $\ldots \ldots \ldots \ldots \ldots \ldots \ldots \ldots \ldots \ldots \ldots \ldots \ldots \ldots, 100$

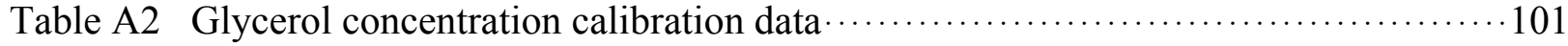

Table A3 Methanol concentration calibration curve $\ldots \ldots \ldots \ldots \ldots \ldots \ldots \ldots \ldots \ldots \ldots \ldots \ldots \ldots \ldots$

Table A4 Protein concentration calibration data $\ldots \ldots \ldots \ldots \ldots \ldots \ldots \ldots \ldots \ldots \ldots \ldots \ldots \ldots \ldots \ldots \ldots$ 


\section{CHPATER 1}

\section{INTRODUCTION}

Mass transfer processes have a major impact on the growth of microorganisms in industrial fermentations. Nutrients must be continuously replenished in the liquid layers closest to the microorganisms since the microorganisms are constantly consuming them. Nutrients such as glucose or ammonia, which can be present in the fermentation media in $1 \mathrm{~mol} / \mathrm{L}$ concentration, cause little mass transfer problem. For aerobic fermentations, oxygen is required as one of the nutrients. At $30^{\circ} \mathrm{C}$ the solubility of oxygen in pure water is $0.236 \mathrm{mmol} / \mathrm{L}$, and the presence of salts and other nutrients required for the growth of any organism reduces this value. Thus, the achievement of high oxygen mass transfer rate is a major challenge in aerobic fermentation.

The oxygen transport in fermenters is roughly proportional to the ratio of the bubble surface area to the bubble volume. Therefore, oxygen transport is roughly proportional to the inverse of the radius of the gas bubbles. In general, the smaller the bubbles, the greater the oxygen transfer rate in the fermenter. Smaller gas bubbles have increased residence time in the fermenter, which is also beneficial to oxygen delivery to the microorganisms. In industrial fermenters, contactors and stirrers reduce the size of bubbles in their immediate vicinity. However, small bubbles coalesce quickly so that bubbles in the rest of the fermenter are approximately 3-5 mm in diameter (Yoshida, 1960). If gas bubbles are stabilized with a surfactant film, they will tend to maintain their small size with, or without stirring. The use of surfactant-stabilized gas bubbles may present a method of taking advantage of the mass transport effects of small bubbles.

It was found that the mass transfer rate of oxygen in fermenters was enhanced when sparged with microbubble dispersions (MBD) (Kaster et al, 1990). Hensirisak (1997) and Parasukulsatid (2000) both showed significant improvement in oxygen transfer to the microorganism in the scale-up of microbubble dispersion for aerobic fermentation of Baker's yeast. The microbubbles are not only small, having diameters of 20-1000 $\mu \mathrm{m}$ compared to diameters of 3-5 mm for normal bubbles in a fermenter, but they are also sturdy and can be 
pumped into the fermenter. These microbubbles rise slowly in normal fluids because of their small size. Surfactant tends to orient at the air-liquid interface, forming a charged bubble surface that repels other bubbles, and thus resists the coalescence of bubbles (Bredwell and Worden, 1998). Since growing microorganisms produce large quantities of surfactant (Oolman and Blanch, 1983), surfactant-stabilized microbubbles could be an efficient means of transferring oxygen to fermentation systems.

Human serum albumin (HSA) is the major protein component of human plasma and consists of a single nonglycosylated polypeptide chain of 585 amino acids with a molecular weight of $66.5 \mathrm{kDa}$ (Mingetti et al., 1986). The albumins contribute significantly to colloid osmotic blood pressure and aid in the transport, distribution, and metabolism of many endogenous and exogenous ligands and are widely used in plasma expanders for the treatment of shock and burns, and to compensate for blood losses as a result of surgery, accidents, or hemorrhages. Albumin has usually been produced by conventional fractionation techniques of plasma obtained from blood donors or human placentas. However, varying blood source causes the potential risk of HSA contamination with blood-derived pathogens. Thus, the development of an alternative method of industrial preparation of HSA is desirable. The development of genetic engineering has opened up the possibility of producing recombinant human serum albumin (rHSA) without the danger of contamination by human pathogens, and at lower cost (Saunders et al., 1987, Sleep et al., 1991, Fleer et al., 1991, Hodgkins et al., 1990, Wartmann et al., 2002).

The methylotrophic yeast Pichia pastoris has been developed as a recombinant DNA system for the expression of heterologous proteins (Klaas,1995) because it is an eukaryotic host, the expressed recombinant protein can undergo the necessary post-translational processing and secretion, results in a product that is either identical or more similar to the native protein (Romanos et al., 1992). These organisms contain an alcohol oxidase (AOX) enzyme that catalyzes the oxidation of methanol to eventually produce carbon dioxide and energy. The production of the AOX, the first enzyme in the methanol utilization pathway is tightly regulated (Gellissen, 2000). Using the highly expressed AOX promoter in a regulated expression vector, the control of the synthesis of foreign proteins such as rHSA can be done by simply altering the carbon source.

The fed-batch fermentation of recombinant HSA secreting P. pastoris is a high oxygen demand process for both the high cell density and secretion of the protein. The oxygen demand is 
usually met by increased agitation rate and use of oxygen-enriched air. However, high agitation rates subject microorganisms to high shear stress and caused high power consumption. The microbubble dispersion method was investigated to improve oxygen transfer at low agitation rates and thus reduce the power consumption and shear stress on microorganisms.

The objective of this research is to investigate the effect of microbubble dispersion on oxygen transfer in the fed-batch fermentation of $P$. pastoris for production of rHSA. In this study, fermentations were run at different agitation rates using either conventional or surfactantstabilized microbubble sparging. Fermentations were also conducted in different types of reactor to see the effect of fermenter design on the oxygen transfer. Cell growth and protein production pattern, as well as dissolved oxygen profile, were compared between different systems at different agitation rates. Protein degradation was also estimated between MBD and conventional systems. 


\section{CHAPTER 2}

\section{LITERATURE REVIEW}

\subsection{Methylotrophic Yeast Pichia pastoris}

The advantages of yeast as hosts for the expression of recombinant proteins from higher eukaryotes have long been appreciated (Romanos et al., 1992). They combine the ease, simplicity, and low cost of bacterial expressions with the authenticity of the far more expensive and less convenient animal tissue culture systems. Like bacteria, yeasts are simple to cultivate on inexpensive growth media, and there is a formidable array of techniques for the manipulation of foreign genes. However, as eukaryotes, they provide an environment for post-translational processing and secretion, resulting in a product that is often identical, or more similar to the native protein.

In the early 1970s, interest in the production of biomass (single-cell protein) from methanol led to the isolation of methylotrophic yeasts from nature (Dijken et al., 1974). Methylotrophic yeasts have the ability to use methanol as a sole source of carbon and energy. Adaptation to growth on methanol is associated with induction of alcohol oxidase (AOX), dihydroxy acetone synthase (DAS), and several other enzymes involved in methanol metabolism. The most spectacular increase, however, is seen with AOX, which is virtually absent in glucose or glycerol grown cells, but can account for over $30 \%$ of the cell protein in methanol-grown cells (Klass et al., 1995).

Pichia pastoris is one of the methylotrophic yeasts which are of both academic and industrial interest. This yeast was initially developed by Phillips Petroleum Company for the production of single-cell protein as a feed stock. The first step in the metabolism of methanol is the oxidation of methanol to formaldehyde using molecular oxygen by AOX. This reaction generates both formaldehyde and hydrogen peroxide. To avoid hydrogen peroxide toxicity, methanol metabolism takes place within a specialized cell organelle called the peroxisome, which sequesters toxic by-products from the rest of the cell (Veenhuis et al., 1983). There are two genes in $P$. pastoris that code for AOX, $A O X 1$ and $A O X 2$. The $A O X 1$ gene product accounts 
for the majority of alcohol oxidase activity in the cell. Expression of the $A O X 1$ gene is tightly regulated and induced by methanol to high levels, typically $\geq 30 \%$ of the total soluble protein in cells grown with methanol as the carbon source. The $A O X 1$ gene has been isolated and the $A O X 1$ promoter is used to drive expression of the gene of interest (Ellis et al., 1985, Koutz et al., 1989). While $A O X 2$ is about $97 \%$ homologous to $A O X 1$, growth on methanol is much slower than with $A O X 1$. This slow growth allows isolation of $\mathrm{Mut}^{\mathrm{S}}$ strains (aoxl) (Cregg et al., 1989).

Heterologous protein expression in P. pastoris involves integration of expression vectors into the $P$. pastoris genome by either single crossover or gene replacement integration strategies. For secretion of foreign proteins, vectors have been constructed that contain a DNA sequence immediately following the $A O X 1$ promoter that encodes a secretion signal. Since 1988, several pharmaceutical and biotechnology companies have licensed the $P$. pastoris expression technology (Klaus et al., 1995). The $P$. pastoris expression system has now been successfully utilized to produce a number of heterologous proteins at commercially interesting concentrations (Table 2.1). As a result, fermentation techniques were developed for maintaining the organism in large-volume continuous culture and at cell densities in excess of 100 grams / liter dry cell weight. The growth medium, a defined mixture of salts, trace elements, biotin and carbon source is inexpensive and can be formulated free of toxins and pyrogens. Fermentation can be conducted over a wide $\mathrm{pH}$ range (3.0-6.0) at $30^{\circ} \mathrm{C}$ (Wegner, 1983).

\subsection{Human Serum Albumin}

Human serum albumin (HSA) is the major protein component of human plasma and consists of a single nonglycosylated polypeptide chain of 585 amino acids with a molecular weight of $66.5 \mathrm{kDa}$ (Mingetti et al., 1986). The albumins contribute significantly to colloid osmotic blood pressure and aid in the transport, distribution and metabolism of many endogenous and exogenous ligands. These ligands represent a spectrum of chemically diverse molecules, including fatty acids, amino acids, steroids, metals such as calcium, copper and zinc, and numerous pharmaceuticals. In addition to blood plasma, serum albumins are also found in tissues and bodily secretions throughout the body; the extravascular protein comprises $60 \%$ of the total albumin (Peters, 1985). 
Table 2.1. Heterologous proteins produced in Pichia pastoris

\begin{tabular}{llll}
\hline Protein & Mode $^{+}$ & Amount (g/l) & Reference \\
\hline Tumor necrosis factor & $\mathrm{I}$ & 8.0 & Sreekrishna et al. 1989 \\
Hepatitis B surface antigen & $\mathrm{I}$ & 0.30 & Cregg et al. 1987 \\
Tetanus toxin fragment C & $\mathrm{I}$ & 12 & Clare et al. 1991 \\
Pertactin (P69) & $\mathrm{I}$ & 3.0 & Romanos et al. 1991 \\
Invertase & $\mathrm{S}$ & 2.5 & Tschopp et al. 1987 \\
Bovine lysozyme & $\mathrm{S}$ & 0.30 & Digan et al. 1989 \\
Human serum albumin (HSA) & $\mathrm{S}$ & 1.40 & Kobayashi et al. 2000 \\
Human epidermal growth factor & $\mathrm{S}$ & 0.50 & Siegel et al. 1990 \\
Mouse epidermal growth factor & $\mathrm{S}$ & 0.45 & Clare et al. 1991 \\
Aprotinin analog & $\mathrm{S}$ & 0.80 & Vedvick et al. 1991 \\
Kunitz protease inhibitor & $\mathrm{S}$ & 1.0 & Wagner et al. 1992 \\
\hline
\end{tabular}

${ }^{+} \mathrm{I}=$ Intracellular, $\mathrm{S}=$ Secreted. 
HSA is widely used in plasma expanders for the treatment of shock and burns, and to compensate for blood losses as a result of surgery, accidents or hemorrhages. Albumin has usually been produced by conventional fractionation techniques of plasma obtained from blood donors or human placentas. However, varying blood source causes the potential risk of HSA contamination with blood-derived pathogens. Thus, the development of an alternative method of industrial preparation of HSA is desired.

The development of genetic engineering has opened up the possibility to obtain recombinant proteins without the danger of contamination by human pathogens, and at lower cost. Saccharomyces cerevisiae strains have long been used as an expression system to secrete rHSA (Sleep et al., 1991). Stable multicopy vectors were also designed for efficient secretion of rHSA by industrial strains of Kluyveromyces yeasts (Fleer et al., 1991). Hansenula polymorpha along with other methylotropic yeasts such as $P$. pastoris can be used to express rHSA in a similar manner to $S$. cerevisiae, but with a higher protein yield (Hodgkins et al., 1990). Wartmann et al. (2002) also developed the non-conventional dimorphic thermo- and saltresistant yeast Arxula adeninivorans as a host for high-level production and secretion of rHSA.

In a his 4 P. pastoris strain such as GS115, a gene replacement ( $\Omega$ insertion) event arises from a double crossover event between the $A O X 1$ promoter and 3' $A O X 1$ regions of the vector and genome. This results in the complete removal of the $A O X 1$ coding region (i.e. gene replacement). The resulting phenotype is $\mathrm{His}^{+} \mathrm{Mut}^{\mathrm{S}}$. $\mathrm{His}^{+}$transformants can be readily and easily screened for their Mut phenotype, with $\mathrm{Mut}^{\mathrm{S}}$ serving as a phenotypic indicator of integration via gene replacement at the $A O X 1$ locus. The net result of this type of gene replacement is a loss of the $A O X 1$ locus $\left(\mathrm{Mut}^{\mathrm{S}}\right.$ ) and the gain of an expression cassette containing $\mathrm{P}_{\mathrm{AOX} 1}$, the gene of interest, and HIS4 (Figure 2.1). The expression of recombinant human serum albumin has been achieved using such expression cassette. The gene for serum albumin was cloned with its native secretion signal, then integrated into Pichia at the AOX1 locus. This strain secretes albumin into the medium at levels $>1 \mathrm{~g} / \mathrm{L}$. 


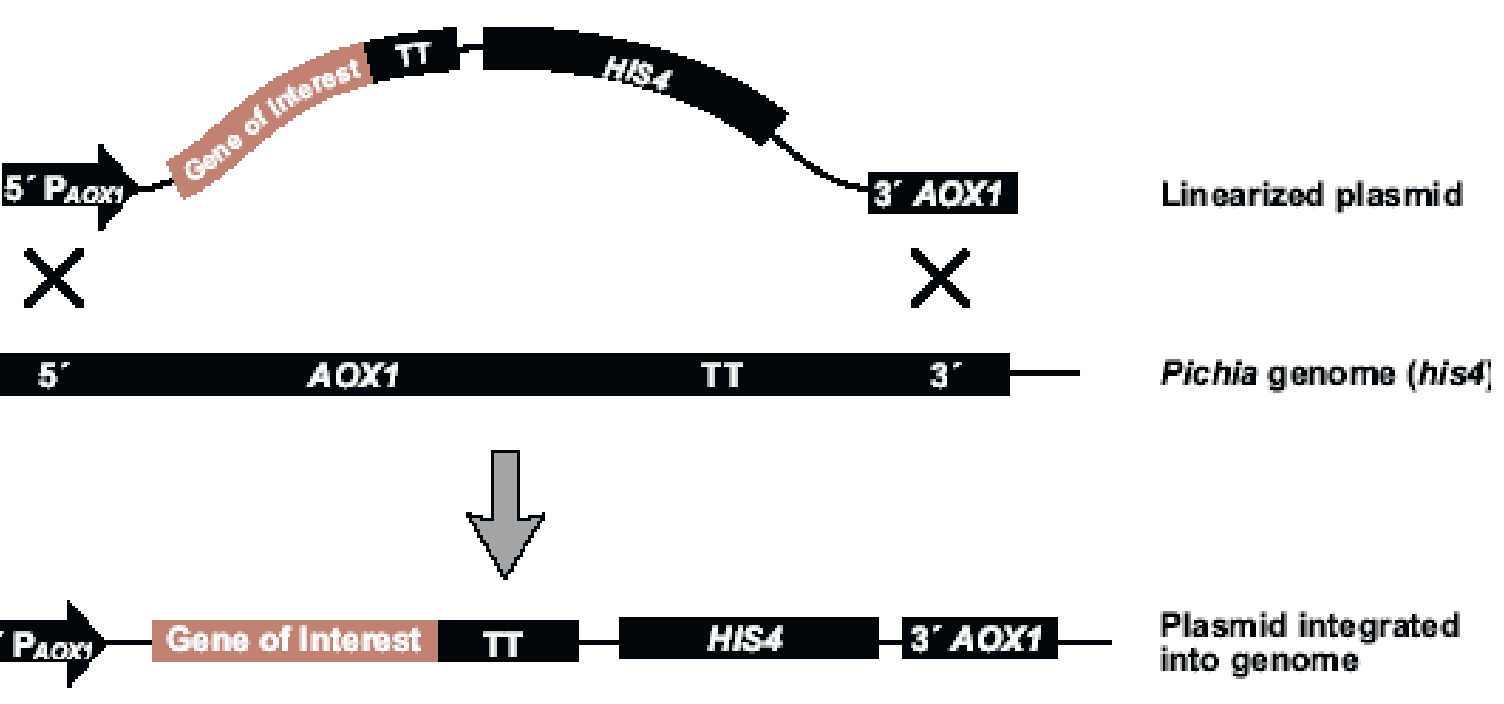

Figure 2.1. Gene replacement event at the $A O X 1$ locus

(Manual of Pichia expression kit, Invitrogen, 2002) 


\subsection{Fermentation of Recombinant HSA Secreting $P$. pastoris}

As described previously $P$. pastoris contains an alcohol oxidase (AOX) that catalyzes the oxidation of methanol to eventually produce carbon dioxide and energy. The production of AOX, the first enzyme in the methanol utilization pathway, is tightly regulated (Gellissen, 2000). Using the highly expressed AOX promoter in a regulated expression vector, the control of the synthesis of foreign proteins such as human serum albumin can be done by simply altering the carbon source.

An efficient rHSA production process in shake flask has been developed based on recombinant P. pastoris (Barr et al., 1992). Highest levels of HSA secretion were found under conditions of a certain range of $\mathrm{pH}$, high aeration, and a fortified medium. A $\mathrm{pH}$ range of 5.80 to 6.4 was found to be optimal for HSA secretion. Adequate aeration improved active secretion because secretion is a high-energy process. A medium fortified with yeast extract and peptone was presumed to serve two purposes of maintaining product stability by reducing proteolysis and keeping cells more energetic.

Fed-batch fermentations of $P$. pastoris for rHSA production were conducted in a 3-L fermenter (Kobayashi et al., 2000). Maximum dry cell weight was around $80 \mathrm{~g} / \mathrm{L}$ and rHSA production reached $360 \mathrm{mg} / \mathrm{L}$ at $96.5 \mathrm{~h}$ of cultivation. Further incubation resulted in the rapid disappearance of rHSA from the culture supernatant, which coincided with a sudden increase in protease activity caused by nitrogen starvation. Kobayashi also found that by using improved medium, production of rHSA increased to $1.4 \mathrm{~g} / \mathrm{L}$ after 250 hours of fermentation. All fermentations were conducted at $30^{\circ} \mathrm{C}$ and a $\mathrm{pH}$ value of 5.85. Throughout the fermentation, the dissolved oxygen was maintained above $10 \%$, which was the critical value for the microorganism.

Wallman (2000) has shown that there were five stages in the process controlled fed-batch fermentation of recombinant HSA secreting P. pastoris. The first stage was a batch growth stage in which the yeast cells after being grown overnight in a shake flask culture of Buffered Glycerol-complex Medium (BMGY) were inoculated into the minimal media in the fermenter. The cells were allowed to adjust to this new media and grow for approximately 24 hours. At this point, the glycerol feed was started in order to achieve maximum cell density. $P$. pastoris is a 
slow growing yeast when grown on methanol so the cell count should be as high as possible before it is switched to the methanol feeding. The third stage was a starvation phase in which the glycerol feeding was stopped and the yeast was allowed to deplete the glycerol in the medium. During the fourth induction stage, methanol was fed at a very low flow rate to shock the cell and induce AOX enzyme for metabolizing the methanol. Once the P. pastoris started to produce the desired protein, HSA, for a short time it was pushed into the final and most important phase, the production phase, where the methanol feed rate was increased.

\subsection{Aeration and Agitation in Aerobic Fermentation}

The majority of fermentation processes are aerobic, and therefore, require the provision of oxygen. If the stoichiometry of respiration is considered, then the oxidation of glucose may be represented as:

$$
\mathrm{C}_{6} \mathrm{H}_{12} \mathrm{O}_{6}+6 \mathrm{O}_{2}=6 \mathrm{H}_{2} \mathrm{O}+6 \mathrm{CO}_{2}
$$

Thus, 192 grams of oxygen are required for the complete oxidation of 180 grams of glucose. However, both components must be in solution before they are available to the microorganism. Oxygen is approximately 6000 times less soluble in water than glucose, thus, it is not possible to provide a microbial culture with all the oxygen it will need for the complete oxidation of the glucose (or any other carbon source) in one addition. Therefore, a microbial culture must be supplied with oxygen during growth at a rate sufficient to meet the organisms' demand.

The oxygen demand of an industrial fermentation process is normally satisfied by aerating and agitating the fermentation broth. However, the productivity of many fermentations is limited by oxygen availability and, therefore, it is important to consider the factors which affect a fermenter's efficiency in supplying microbial cells with oxygen. 


\subsubsection{Oxygen Requirements of Fermentations}

The analysis of the stoichiometry of respiration gives an appreciation of the problem of oxygen supply. However, it gives no indication of an organism's true oxygen demand as it does not take into account the carbon that is converted into biomass and products. A number of workers (Darlington 1964, Johnson 1964, and Mateles 1971) have used the incorporation of oxygen, carbon, and nitrogen into biomass to predict the oxygen demand for fermentation. They found that a culture's demand for oxygen is very much dependent on the source of carbon in the medium. Thus, the more reduced the carbon source, the greater will be the oxygen demand. Darlington (1964) and Johnson (1964) demonstrated that 100 grams of biomass from hydrocarbon requires approximately three times the amount of oxygen to produce the same amount of biomass from carbohydrate. Later, product formation as well as biomass production by oxygen conversion was calculated (Righelato et al., 1968, Cooney 1979).

\subsubsection{Oxygen Transfer in the Fermenter}

During fermentation, the transfer of oxygen from air to the cell occurs in a number of steps (Bartholomew et al., 1950):

(i) The transfer of oxygen from an air bubble into solution.

(ii) The transfer of the dissolved oxygen through the fermentation medium to the microbial cell.

(iii) The uptake of the dissolved oxygen by the cell.

It was demonstrated in a Streptomyces griseus fermentation that the limiting step in the transfer

of oxygen was the transfer of oxygen into solution. Their findings have been shown to be correct for non-viscous fermentations, but it has been demonstrated that oxygen transfer may be limited by either of the other two stages in some highly viscous fermentations.

The rate of oxygen transfer from air bubble to the liquid phase may be described by the equation:

$$
\mathrm{d} C_{L} / \mathrm{dt}=k_{L} a\left(C^{*}-C_{L}\right)
$$


where $C_{L}=$ concentration of dissolved oxygen in fermentation broth (mmoles $\mathrm{dm}^{-3}$ ),

$\mathrm{t}=$ time $(\mathrm{h})$,

$\mathrm{d} C_{L} / \mathrm{dt}=$ change in oxygen concentration over a time period, i.e. the oxygen transfer rate $\left(\right.$ mmoles $\left.\mathrm{O}_{2} \mathrm{dm}^{-3} \mathrm{~h}^{-1}\right)$,

$k_{L}=$ liquid-phase mass transfer coefficient $\left(\mathrm{cm} \mathrm{h}^{-1}\right)$,

$a=$ gas-liquid interface area per liquid volume $\left(\mathrm{cm}^{2} \mathrm{~cm}^{-3}\right)$,

$C^{*}=$ saturated dissolved oxygen concentration $\left(\right.$ mmols $\left.\mathrm{dm}^{-3}\right)$.

From the Eq. (2-2), it is clear that three parameters are involved in the oxygen transfer rate: the liquid-phase mass transfer coefficient $\left(k_{L}\right)$, the gas-liquid interfacial area per liquid volume $(a)$ and the concentration driving force $\left(C^{*}-C\right)$. It is extremely difficult to measure both ' $k_{L}$ ' and ' $a$ ' during fermentation and, therefore, the two terms are generally combined in the term $k_{L} a$, the volumetric mass-transfer coefficient, having units of reciprocal time $\left(\mathrm{h}^{-1}\right)$.

The volumetric mass-transfer coefficient is used as a measure of aeration capacity of a fermenter. The larger the $k_{L} a$, the higher the aeration capacity of the system. The $k_{L} a$ value will depend upon the design and operating conditions of the fermenter and will be affected by such variables as aeration rate, agitation rate and impeller design. These variables affect ' $k_{L}$ ' by reducing the resistances to transfer and affect ' $a$ ' by changing the number, size, and residence time of air bubbles.

\subsubsection{Factors Affecting $k_{L} a$ values}

A number of factors have been demonstrated to affect the $k_{L} a$ value achieved in a fermentation vessel. Such factors include the bubble size, the degree of agitation, the air-flow rate, the rheological properties of the culture broth, and the presence of antifoam agents.

\section{Bubble Size}

The value of $k_{L} a$ is strongly affected by the bubble characteristics in the liquid medium. The size of air bubbles is the most important variable (Motarjemi and Jameson, 1978). Small air 
bubbles have more interfacial area $a$ than large air bubbles, which cause increased $k_{L} a$ value. Small bubbles have other important characteristics such as slow rising velocity and high gas hold-up. Slow rising velocities keep air bubbles in the liquid longer, allowing more time for the oxygen to dissolve. Small bubbles create high gas hold-up, defined as the fraction of the fluid volume in the reactor occupied by gas:

$$
\varepsilon=\frac{V_{G}}{V_{L}+V_{G}}
$$

where $\quad \varepsilon=$ gas hold-up

$V_{G}=$ volume of gas bubbles in the reactor $\left(\mathrm{m}^{3}\right)$, and

$V_{L}=$ volume of liquid in the reactor $\left(\mathrm{m}^{3}\right)$

The total interfacial area for oxygen transfer depends on the total volume of gas in the system as well as on the average bubble size. High gas hold-up gives a high oxygen transfer rate because the total volume of the air bubbles in the fermenter is greater. Decreased bubble size largely increases total interfacial area of the gas bubbles. Kaster et al. (1990), Hensirisak (1997), and Parakulsuksatid (2000) demonstrated that a microbubble dispersion increased oxygen transfer rate in aerobic fermentation of yeast. A given volume of gas dispersed into many small bubbles rather than a few large ones provides more interfacial area, $a$. Since the efficiency of oxygen transport is approximately proportional to the ratio of the bubble surface area to the bubble volume, the smaller size bubbles increase oxygen transfer rate in the fermenter.

\section{Degree of Agitation}

The degree of agitation has been demonstrated to have a profound effect on the oxygentransfer efficiency of an agitated fermenter. Banks (1977) reported that agitation assisted oxygen transfer in the following ways:

(i) Agitation increases the area available for oxygen transfer by dispersing the air in the culture fluid in the form of small bubbles.

(ii) Agitation delays the escape of air bubbles from the liquid. 
(iii) Agitation prevents coalescence of air bubbles.

(iiii) Agitation decreases the thickness of the liquid film at the gas-liquid interface by creating turbulence in the culture fluid.

The degree of agitation may be measured by the amount of power consumed in stirring the vessel contents. A large number of empirical relationships have been developed between $k_{L} a$, power consumption and superficial air velocity which can be generally expressed as:

$$
k_{L} a=k\left(P_{g} / V\right)^{x} V_{S}^{y}
$$

where $P_{g}=$ power absorption in an aerated system

$V=$ liquid volume in the vessel

$V_{S}=$ superficial air velocity

$k, x$ and $y=$ empirical factors specific to the system under investigation.

Bartholomew (1960) demonstrated that the relationship depended on the size of the vessel and the exponent on the term $P_{g} / V$ varied with scale (Table 2.2).

In a laboratory scale fermenter, the $k_{L} a$ value was almost directly proportional to the gassed power consumption per unit volume, and the relationship is scale-dependent. Van't (1983) summarized the various correlations for coalescing air-water dispersion systems as falling within $20-40 \%$ of: $\mathrm{k}=0.026, \mathrm{x}=0.4$, and $\mathrm{y}=0.5$. The common feature of these relationships is that the values of $x$ and $y$ are less than unity. Winkler (1990) pointed out that this means that increasing power input or air flow becomes progressively less efficient as the inputs rise. Thus, high oxygen-transfer rates are achieved at considerable expense.

\section{Air-flow Rate}

The effect of air flow rate on $k_{L} a$ values in conventionally agitated systems is illustrated in Figure 2.2. The air flow rate employed rarely falls outside the range of 0.5-1.5 volumes of air per volume of medium per minute, and this rate tends to be maintained constant on scale-up.

If the impeller is unable to disperse the incoming air, then extremely low oxygen transfer rates may be achieved due to the impeller becoming 'flooded'. A schematic representation of 
Table 2.2 The exponent on $P_{g} / V$ varied with scale (Bartholomew, 1960)

\begin{tabular}{cc}
\hline Scale & Value of exponent on $P_{g} / V$ \\
\hline Laboratory & 0.95 \\
Pilot plant & 0.67 \\
Production plant & 0.5 \\
\hline
\end{tabular}




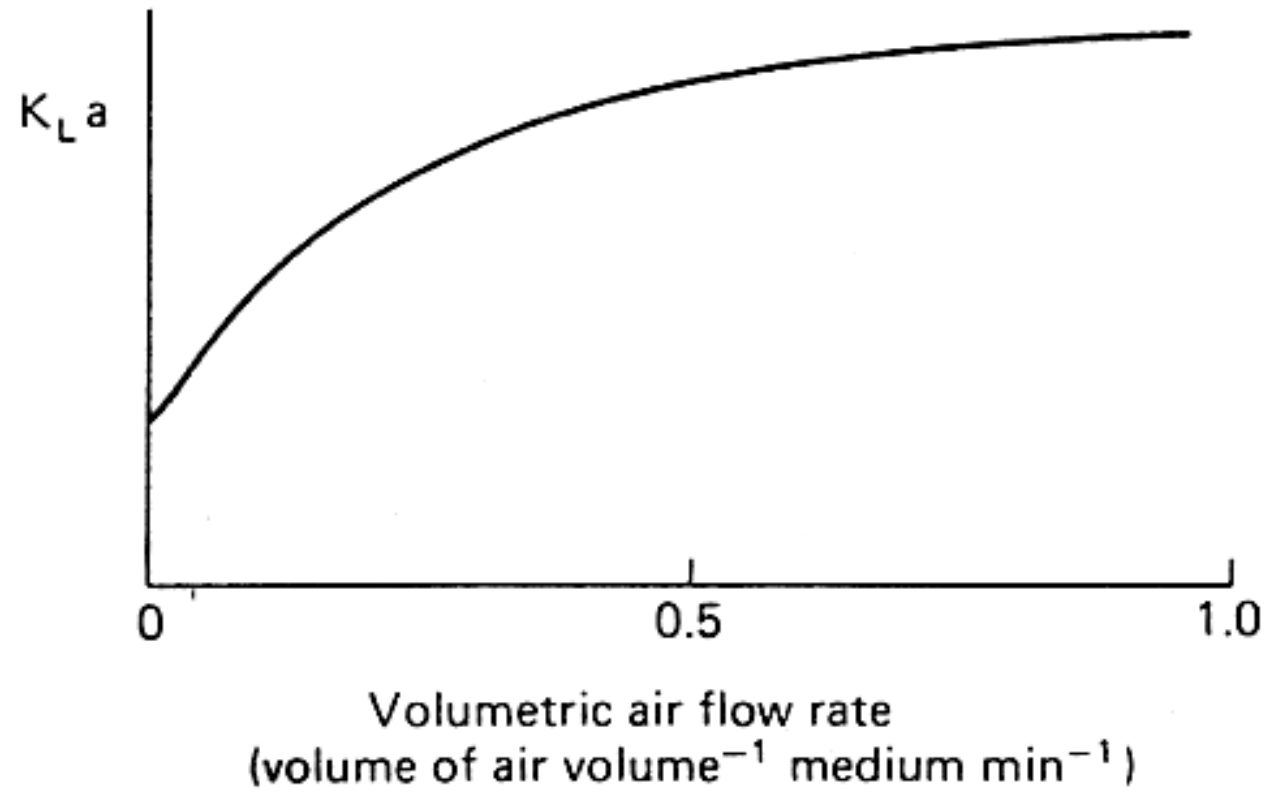

Figure 2.2. The effect of air-flow rate on the $k_{L} a$ of an agitated aerated vessel (Stanbury, 1995) 
airflow rate (aeration) and impeller speed (agitation) is shown in Figure 2.3. Flooding is the phenomenon where the air-flow dominates the flow pattern due to an inappropriate combination of high air-flow rate and low speed of agitation (Figure $2.3 \mathrm{a}$ ). As the impeller speed increases, gas is captured behind the agitator blades and is dispersed into the liquid. Figure 2.3 (b) shows the minimum stirrer speed required to completely disperse the gas. With further increases in stirrer speed, small recirculation pattern start to emerge as indicated in Figure 2.3 (c) and (d). The desired dispersion pattern is shown in Figure $2.3(\mathrm{e})$.

\section{Medium Rheology}

A Newtonian liquid has a constant viscosity regardless of shear, so that the viscosity of a Newtonian fermentation broth will not vary with agitation rate. However, a non-Newtonian liquid does not obey Newton's law of viscous flow and does not have a constant viscosity. Thus, the viscosity of a non-Newtonian fermentation broth will vary with agitation rate and is described as an apparent viscosity $\left(\mu_{\mathrm{a}}\right)$. Buckland et al. (1988), using different agitator systems, reported that the $k_{L} a$ was inversely proportional to the square root of the broth viscosity, i.e.:

$$
k_{L} a \propto 1 / \sqrt{v i s \cos i t y}
$$

A fermentation broth consists of the liquid medium in which the organism grows, the microbial biomass, and product secreted by the organism. Thus, the rheology of the broth is affected by the composition of the original medium and its modification by the growing culture, the concentration and morphology of the biomass and the concentration and rheological properties of the microbial products. Therefore, fermentation broths vary widely in their rheological properties and significant changes in broth rheology may occur during a fermentation, which may have marked influence on the relationship between $k_{L} a$ and the degree of agitation. 


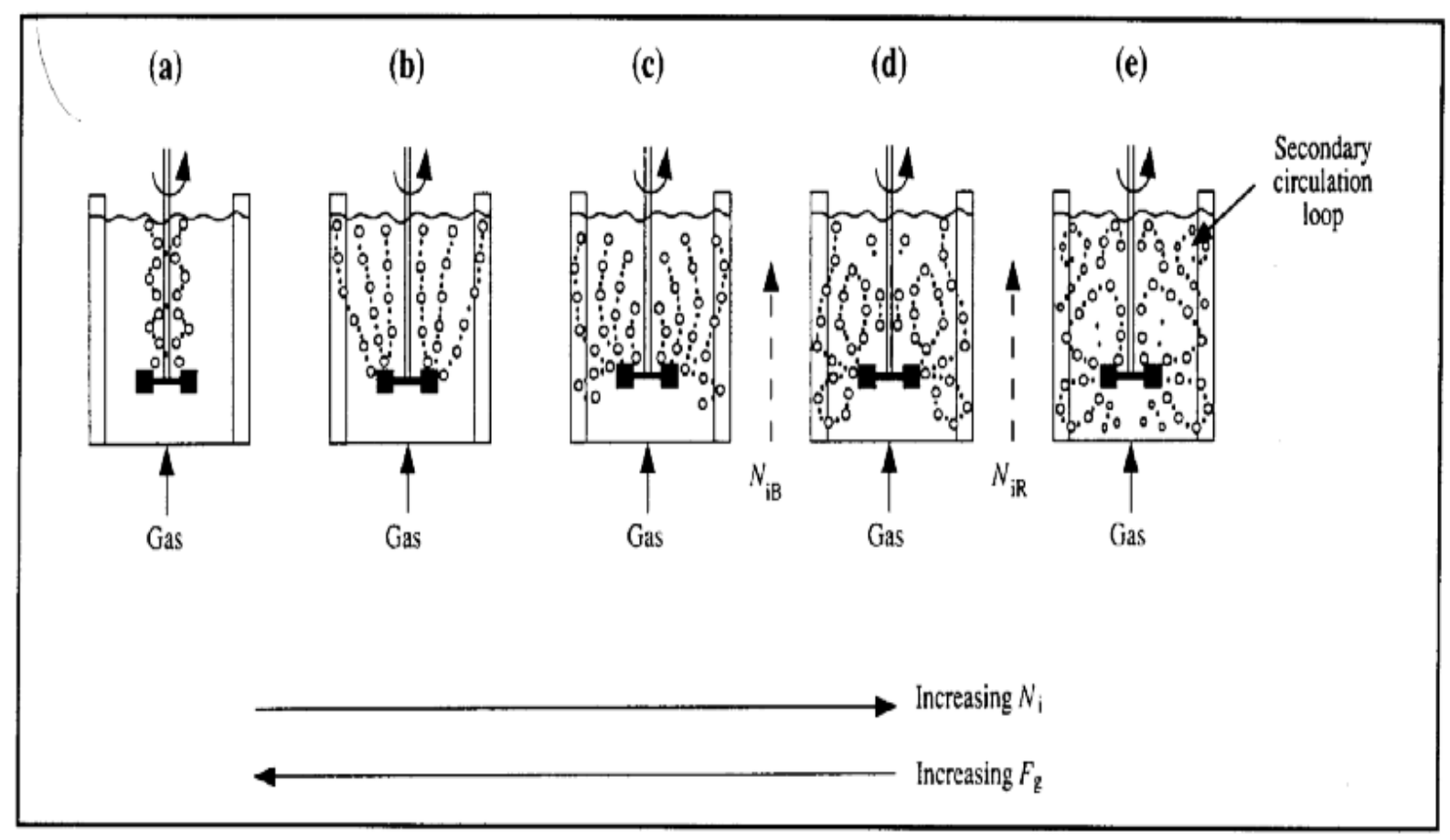

Figure 2.3. Different patterns of gas bubble dispersion in a stirred-tank reactor (Doran, 1995) 


\section{Antifoam Agents}

The high degree of aeration and agitation required in a fermentation frequently gives rise to the undesirable phenomenon of foam formation. In extreme circumstances, the foam may overflow from the fermenter via the air outlet or sample line resulting in the loss of medium and product, as well as increasing the risk of contamination. The presence of foam may also have an adverse effect on the oxygen-transfer rate. Thus, antifoams need to be added to break down the foam.

All antifoams are surfactants and may, themselves, be expected to have some effect on oxygen transfer. The predominant effect observed is that antifoams tend to decrease the oxygentransfer rate (Aiba et al., 1973). Antifoams cause the collapse of bubbles in foam but they may favor the coalescence of bubbles within the liquid phase, resulting in larger bubbles with reduced surface area to volume ratios and hence a reduced rate of oxygen transfer (Van't and Van, 1992). Thus, a balance must be struck between the necessity for foam control and the deleterious effects of the controlling agent. Van't and Van (1992) observed that, above a critical liquid height, the $k_{L} a$ value decreases dramatically due to the excessive use of antifoams.

\subsection{Determination of $k_{L} a$ value}

The determination of the $k_{L} a$ value of a fermenter is essential in order to establish its aeration efficiency and to quantify the effects of operating variables on the provision of oxygen. Calculation using empirical correlation and experimental measurement are two approaches to evaluating $k_{L} a$. The empirical correlation has been mentioned previously in Eq. (2-4). However, in practice, the accuracy of published correlations applied to biological systems is strongly affected by the additives usually present in the fermentation media. Fermentation liquids contain different kinds of substrates, products, salts, surface-active agents and cells, hence bubble surface chemistry and mass transfer effects become complex. Prediction of $k_{L} a$ under these conditions is difficult. 
Due to the difficulty in predicting $k_{L} a$ in bioreactors using correlations, mass transfer coefficients for oxygen are usually determined experimentally. There have been developed several methods to estimate the oxygen transfer rate in fermenters.

\subsubsection{The Sulphite Oxidation Technique}

Cooper et al. (1944) were the first to describe the determination of oxygen-transfer rates in aerated vessels by the oxidation of sodium sulphite solution. This technique does not require the measurement of dissolved oxygen concentrations but relies on the rate of conversion of a 0.5 M solution of sodium sulphite to sodium sulphate in the presence of a copper or cobalt catalyst:

$$
\mathrm{Na}_{2} \mathrm{SO}_{3}+0.5 \mathrm{O}_{2}=\mathrm{Na}_{2} \mathrm{SO}_{4}
$$

The rate of reaction is such that as oxygen enters solution it is immediately consumed in the oxidation of sulphite, so that the sulphite oxidation rate is equivalent to the oxygen-transfer rate. The dissolved oxygen concentration, for all practical purposes, will be zero and the $k_{L} a$ may then be calculated from the equation:

$$
\mathrm{OTR}=k_{L} a C^{*}
$$

Where $\mathrm{OTR}=$ oxygen transfer rate

The procedure is carried out as follows: the fermenter is filled with a $0.5 \mathrm{M}$ solution of sodium sulphite containing $10^{-3} \mathrm{M} \mathrm{Cu}^{2+}$ ions and aerated and agitated at fixed rates; samples are removed at set time intervals (depending on the aeration and agitation rates) and added to excess iodine solution which reacts with the unreacted sulphite, the level of which may be determined by a back titration with standard sodium thiosulphate solution. The volumes of the thiosulphate titrations are plotted against sample time and the oxygen transfer rate may be calculated from the slope of the graph.

The sulphite oxidation method has the advantage of simplicity and also, the technique involves sampling the bulk liquid in the fermenter and therefore, removes some of the problems of conditions varying through the volume of the vessel. However, the method is time consuming 
(one determination taking up to 3 hours, depending on the aeration and agitation rates) and is inaccurate. Bell and Gallo (1971) demonstrated that minor amounts of surface-active contaminants (such as amino acids, proteins, fatty acids, esters, lipids, etc.) could have a major effect on the accuracy of the technique and apparent differences in aeration efficiency between vessels could be due to differences in the degree of contamination. Also, the rheology of a sodium sulphite solution is completely different from that of a fermentation broth, especially a mycelial one so that it is impossible to relate the results of sodium sulphite determinations to real fermentations.

\subsubsection{Gassing-out Technique}

The estimation of the $k_{L} a$ of a fermentation system by gassing-out techniques depends upon monitoring the increase in dissolved oxygen concentration of a solution during aeration and agitation. The oxygen transfer rate will decrease during the period of aeration as $C_{L}$ approaches

$C^{*}$ due to the decline in the driving force $\left(C^{*}-C_{L}\right)$. The oxygen transfer rate, at any one time, will be equal to the slope of the tangent to the curve of for dissolved oxygen concentration against aeration time, as shown in Figure 2.4.

To monitor the increase in dissolved oxygen over an adequate range it is necessary first to decrease the oxygen level to a low value. Two methods have been employed to achieve this lowering of the dissolved oxygen concentration - the static method and dynamic method.

\section{Static Method of Gassing Out}

In this technique, first described by Wise (1951), the oxygen concentration of the solution is lowered by gassing the liquid out with nitrogen gas, so that the solution is 'scrubbed' free of oxygen. The deoxygenated liquid is then aerated and agitated and the increase in dissolved oxygen monitored using some form of dissolved oxygen probe. The increase in dissolved oxygen concentration has already been described by Eq. 2.2, i.e.:

$$
\mathrm{d} C_{L} / \mathrm{dt}=k_{L} a\left(C^{*}-C_{L}\right)
$$




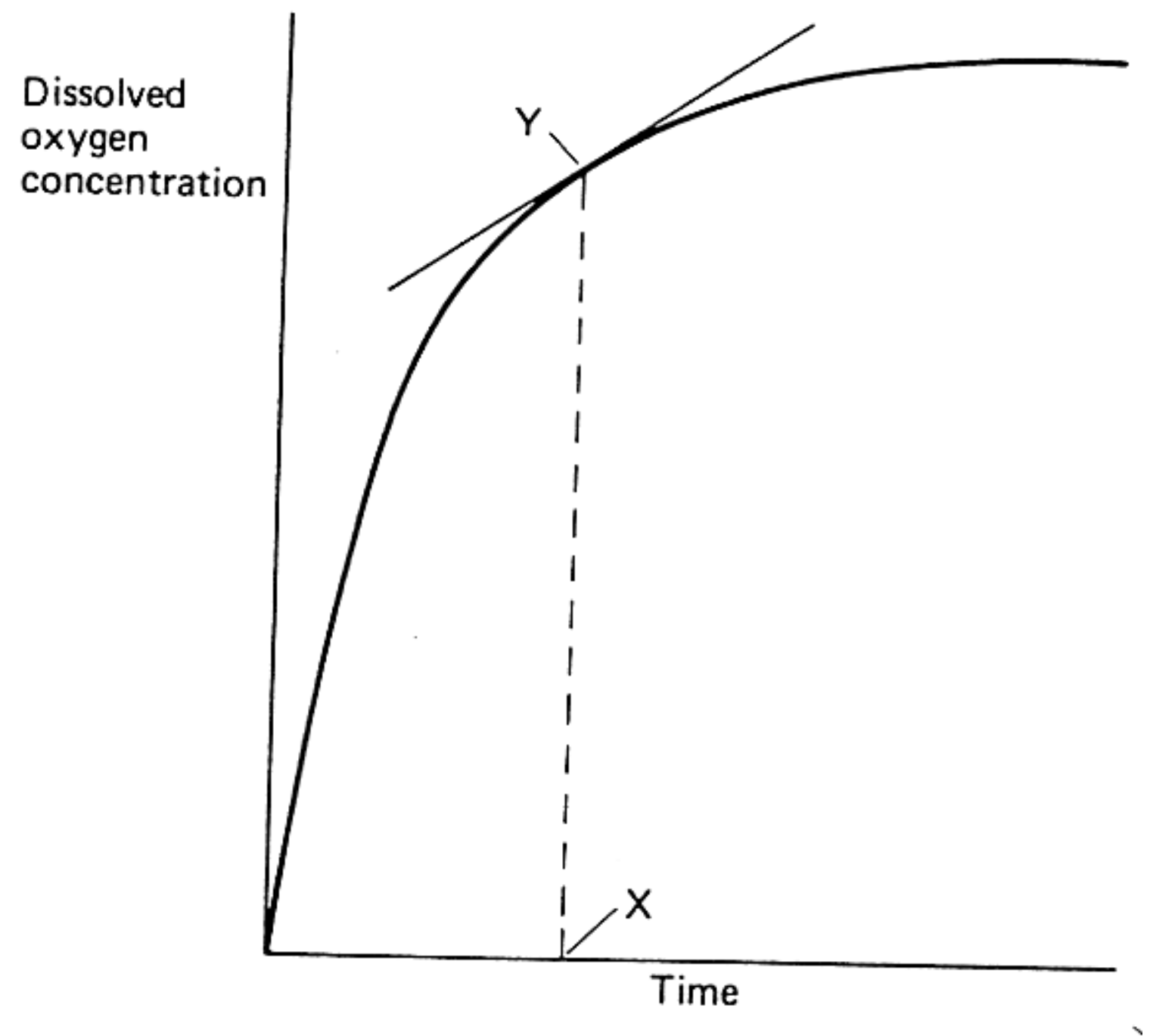

Figure 2.4. The increase in dissolved oxygen concentration of a solution over a period of aeration. The oxygen transfer rate at time $\mathrm{X}$ is equal to the slope of the tangent at point $Y$. (Wise, 1951) 
and depicted in Figure 2.4. Integration of equation (2-2) yields:

$$
\ln \left(C^{*}-C_{L}\right)=-k_{L} a t
$$

Thus, a plot of $\ln \left(C^{*}-C_{L}\right)$ against time will yield a straight line of slope $-k_{L} a$, as shown in Figure 2.5. This technique has the advantage over the sulphite oxidation method in that it is very rapid (normally taking up to 15 minutes) and may utilize the fermentation medium, to which may be added dead cells or mycelium at a concentration equal to that produced during the fermentation.

Employing the fermentation medium with, or without, killed biomass necessitates the use of a membrane-type electrode, the response time of which may be inadequate to reflect the true change in the rate of oxygenation over a short period of time. The probe response time $\left(T_{p}\right)$ is defined as the time needed to record $63 \%$ of a stepwise change and this should be much smaller than the mass transfer response time of the system (1/ $\left.k_{L} a\right)$. According to Van't (1979), the use of commercially available electrodes, with a response time of 2 to 3 seconds, should enable a $k_{L} a$ of up to $360 \mathrm{~h}^{-1}$ to be measured with little loss of accuracy.

While the method is acceptable for small scale vessels, there are severe limitations to its use on large scale fermenters which have high gas residence time. When the air supply to such a vessel is resumed after deoxygenation with nitrogen, the oxygen concentration in the gas phase may change with time as the nitrogen is replaced with air. Thus, $C^{*}$ will no longer be constant. 


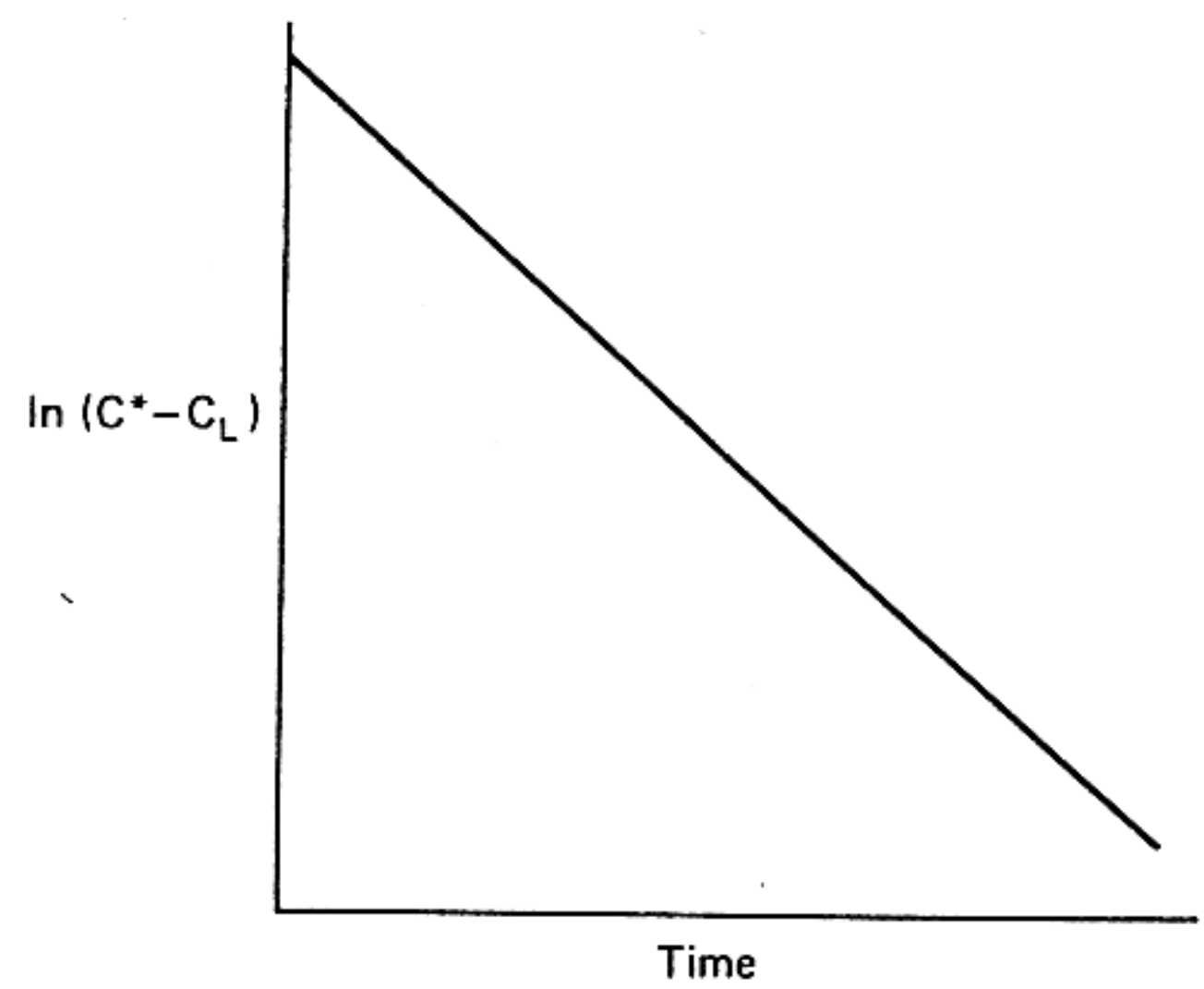

Figure 2.5. A plot of the $\ln \left(C^{*}-C_{L}\right)$ against time of aeration, the slope of which equals $-k_{L} a$. (Wise, 1951) 


\section{Dynamic Method of Gassing Out}

Taguchi and Humphrey (1966) utilized the respiratory activity of a growing culture in the fermenter to lower the oxygen level prior to aeration. Therefore, the estimation has the advantage of being carried out during a fermentation which should give a more realistic assessment of the fermenter's efficiency. Because of the complex nature of fermentation broths the probe used to monitor the change in dissolved oxygen concentration must be of the membrane-covered type referred to previously.

The procedure involves stopping the supply of air to the fermentation which results in a linear decline in the dissolved oxygen concentration due to the respiration of the culture, as shown in Figure 2.6. The slope of the line AB in Figure 2.6 is a measure of the respiration rate of the culture. At point $\mathrm{B}$ the aeration is resumed and the dissolved oxygen concentration increases until it reaches concentration X. Over the period, BC, the observed increase in dissolved oxygen concentration is the difference between the transfer of oxygen into solution and the uptake of oxygen by the respiring culture as expressed by the equation:

$$
d C_{L} / d t=k_{L} a\left(C^{*}-C_{L}\right)-x Q_{O 2}
$$

where $x=$ concentraton of biomass and

$$
Q_{O 2}=\text { specific respiration rate }\left(\text { mmols of oxygen } \mathrm{g}^{-1} \text { biomass } \mathrm{h}^{-1}\right. \text { ) }
$$

The term $x Q_{O 2}$ is given by the slope of the line $\mathrm{AB}$ in Figure 2.6. Equation (2-8) may be rearranged as

$$
C_{L}=-1 / k_{L} a\left\{\left(d C_{L} / d t\right)+x Q_{O 2}\right\}+C^{*}
$$

Thus, from Eq. 2.9, a plot of $C_{L}$ versus $d C_{L} / d t+x Q_{O 2}$ will yield a straight line, the slope of which will equal $-1 / k_{L} a$, as shown in Figure 2.7 .

The dynamic gassing-out method has the advantage over the previous methods of determining the $k_{L} a$ during an actual fermentation and may be used to determine $k_{L} a$ values at 
different stages in the process. The technique is also rapid and only requires the use of a dissolved-oxygen probe, of the membrane type. A major limitation in the operation of the technique is the range over which the increase in dissolved oxygen concentration may be measured. It is important not to allow the oxygen concentration to drop below the critical value during the deoxygenation step as the specific oxygen uptake rate will then be limited and the term $x Q_{O 2}$ would not be constant on resumption of aeration. The occurrence of oxygen-limited conditions during deoxygenation may be detected by the deviation of the decline in oxygen concentration from a linear relationship with time, as shown in Figure 2.8.

When the oxygen demand of a culture is very high it may be difficult to maintain the dissolved oxygen concentration significantly above $\mathrm{C}_{\text {crit }}$ during the fermentation so that the range of measurements which could be used in the $k_{L} a$ determination would be very small. Thus, it may be difficult to apply the technique during a fermentation which has an oxygen demand close to the supply capacity of the fermenter.

Although the difficulty presented by nitrogen degassing does not arise with the dynamic method, it is also not suitable for use with vessels in excess of one meter high. In such vessels the time taken to establish an equilibrium population of air bubbles would be significant and the gas-liquid interface area would change over the aeration period resulting in a considerable underestimation of the $k_{L} a$ value achievable under normal operating conditions. Both the dynamic and static methods are also unsuitable for measuring $k_{L} a$ values in viscous systems. This is due to the very small bubbles $(<1 \mathrm{~mm}$ diameter) formed in a viscous system which have an extended residence time compared with 'normal' sized bubbles. Thus, the gassing out techniques are only useful on a small scale with non-viscous systems. 


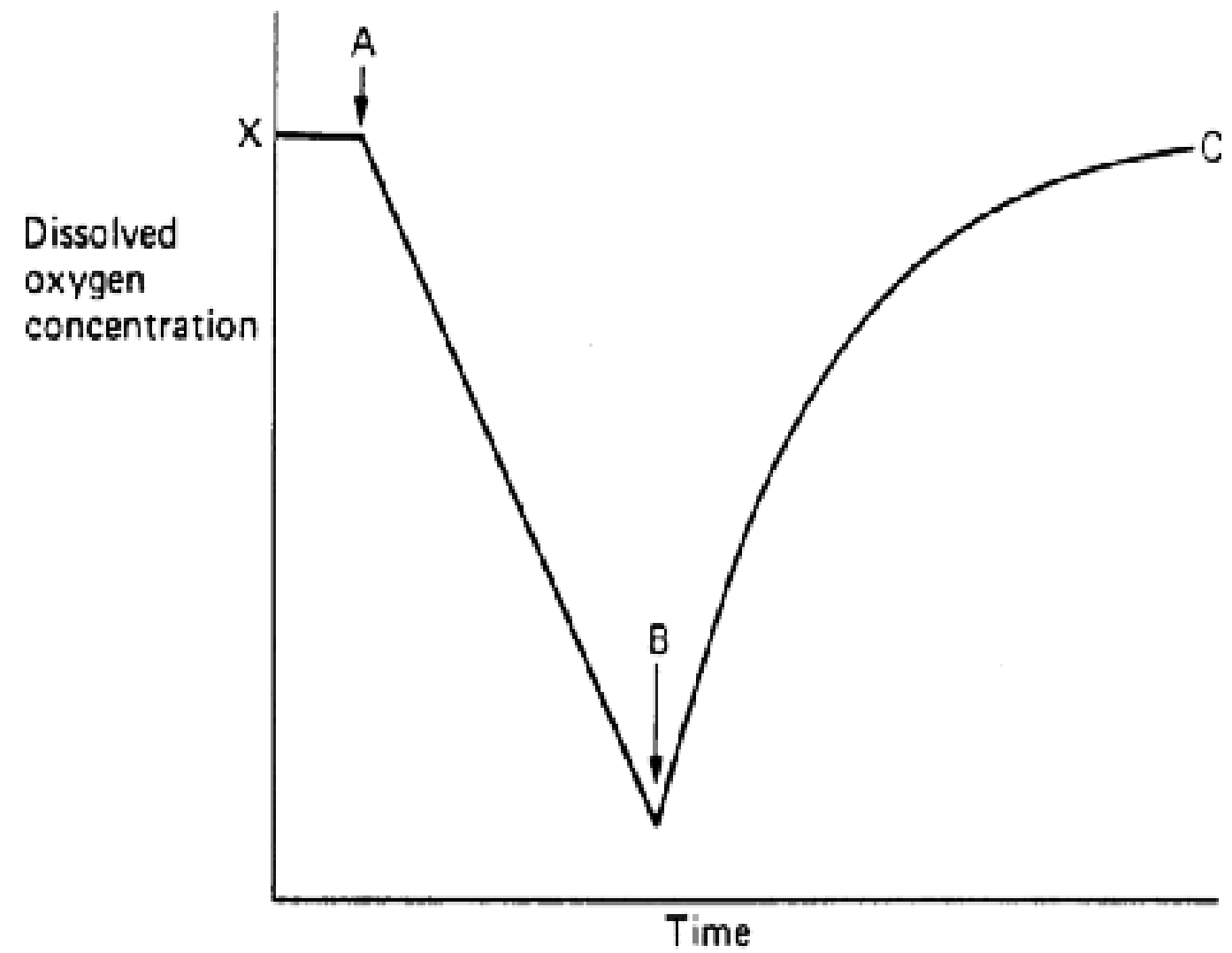

Figure 2.6. Dynamic gassing out for the determination of $k_{L} a$ values.

Aeration was terminated at point A and recommenced at point B. (Taguchi, 1966) 


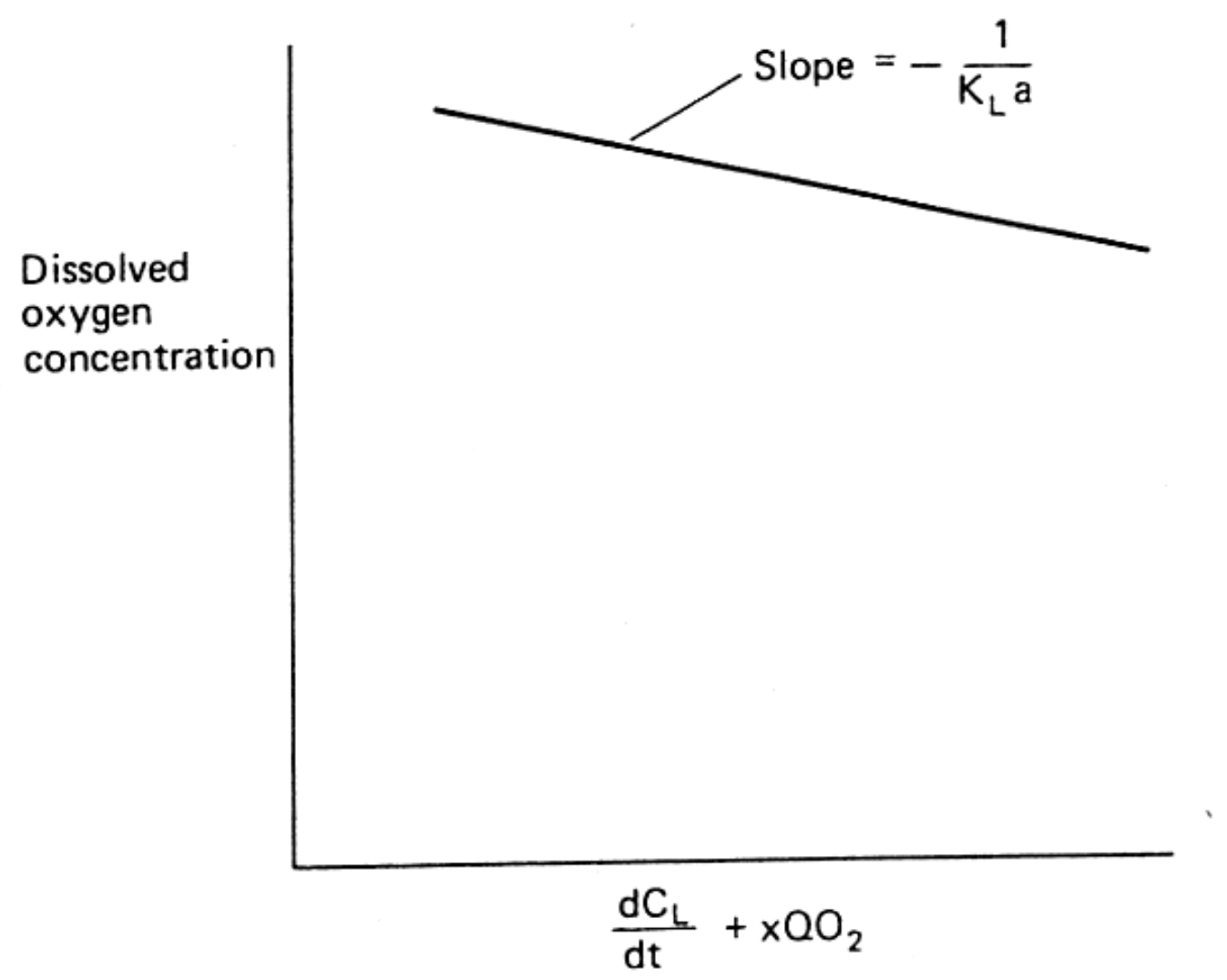

Figure 2.7. The dynamic method for determinatin of $k_{L} a$ values.

The information was obtained from Fig. 2.5. By taking tangents of the curve, $\mathrm{BC}$, at various values of $C_{L}$. (Taguchi, 1966) 


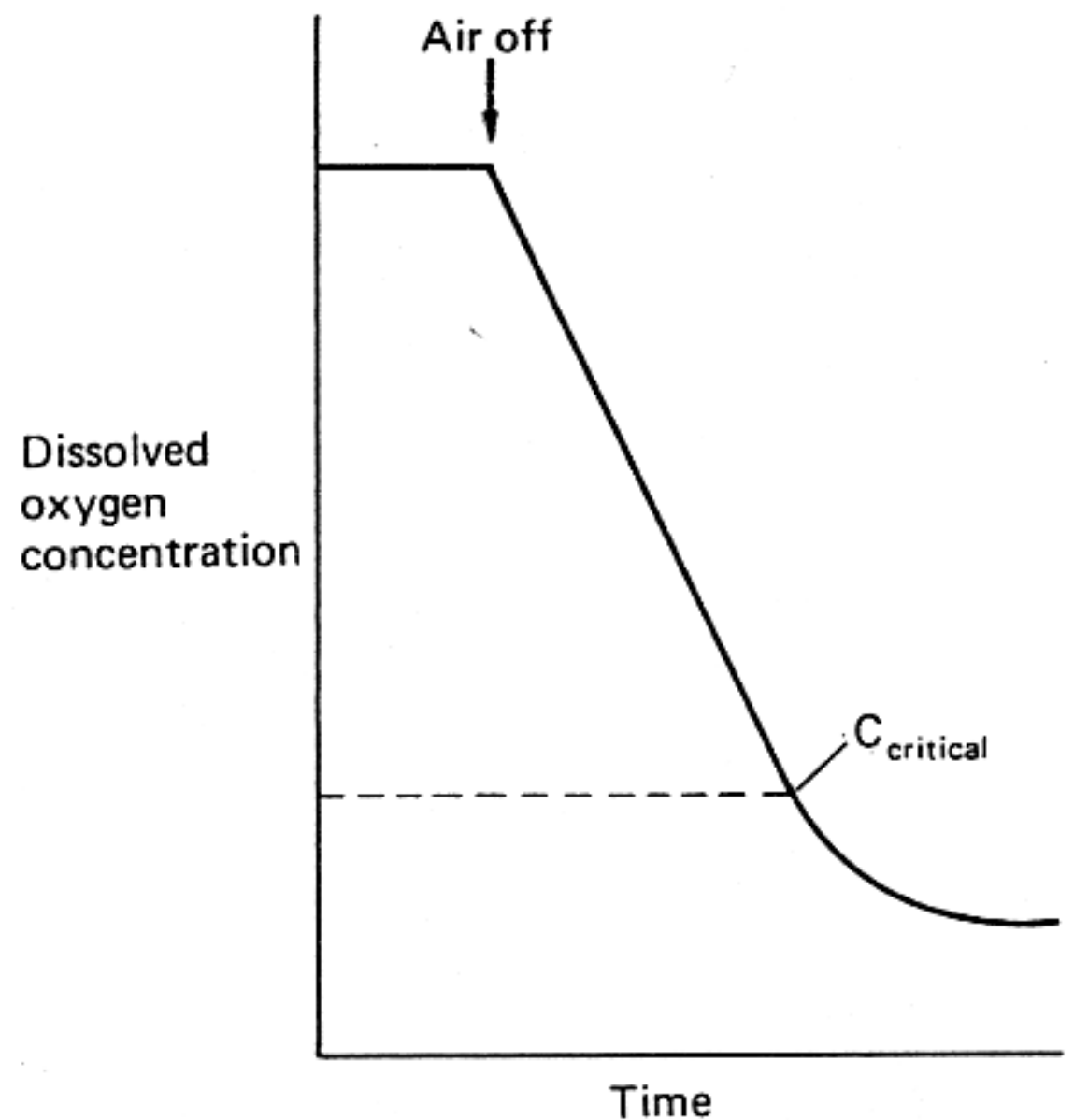

Figure 2.8. The occurrence of oxygen limitation during the dynamic gassing out of a fermentation. (Taguchi, 1966) 


\subsubsection{Yield Coefficient Method}

The yield coefficient method gives an alternative and simple method, which, under certain circumstances, proves quite satisfactory for estimating the oxygen uptake rate by microorganisms during fermentation. This method measures the oxygen uptake rate by microorganisms during fermentation rather than the rate of depletion of oxygen in the gas-liquid phase. The oxygen uptake rate is the rate that microorganisms in fermenters consume oxygen during fermentation. This technique applies the stoichiometric relationships between oxygen and cell mass together with the kinetic data for growth. The oxygen uptake rate of microorganisms (Wang et at, 1979) is shown as:

$$
Q o=\mu X\left(K^{\prime} / Y_{0}\right)
$$

where

$$
\begin{aligned}
& Q o=\text { oxygen uptake rate }\left(\operatorname{mmol~} \mathrm{O}_{2} \mathrm{~L}^{-1} \mathrm{~h}^{-1}\right), \\
& \mu=\text { specific growth rate of microorganisms }\left(\mathrm{h}^{-1}\right), \\
& X=\text { cell mass }\left(\mathrm{g} \text { cell mass } \mathrm{L}^{-1}\right), \\
& K^{\prime}=\text { conversion factor }=31.25\left(\mathrm{mmol} \mathrm{O}_{2} \mathrm{~g} \mathrm{O}_{2}^{-1}\right) \text {, and } \\
& Y_{\mathrm{O}}=\text { yield coefficient on oxygen }\left(\mathrm{g}^{-1} \text { cell mass g O }{ }_{2}^{-1}\right) .
\end{aligned}
$$

In equation (2-11), the oxygen yield coefficient is the only unknown variable. The oxygen consumed to produce cell mass is difficult to measure. However, it should be recognized that the oxygen yield coefficient is dependent on substrate yield coefficient ( $Y_{S}=$ gram of cells / gram of substrate consumed). Therefore, the values of $Y o$ are generally calculated from the substrate and cell stoichiometric relationships and substrate yield coefficients. A generalized method for calculating the oxygen yield coefficient was shown by Mateles (1971) to be 


$$
\frac{1}{Y_{O}}=\frac{g O_{2}}{\text { gcells }}=16\left[\frac{2 C+H / 2-O}{Y_{S} M}+\frac{O^{\prime}}{1600}-\frac{C^{\prime}}{600}+\frac{N^{\prime}}{933}-\frac{H^{\prime}}{200}\right]
$$

where

$Y o=$ oxygen yield coefficient in g cells $/ \mathrm{g} \mathrm{O}_{2}$,

$\mathrm{C}, \mathrm{H}, \mathrm{O}=$ number of atoms of carbon, hydrogen and oxygen in the substrate, $Y_{S}=$ substrate yield coefficient in $\mathrm{g}$ cells/g substrate

$\mathrm{M}=$ molecular weight of substrate,

O', C', N', H' = percent of oxygen, carbon, nitrogen, and hydrogen in the cell, respectively.

Using equation (2-12) and published data on the cell composition for bacteria and yeast, the oxygen yields for various types of substrates were calculated by Mateles (1971) and are shown in Figure 2.9

It should be mentioned that calculating the oxygen yield coefficient using equation (2-12) assumes that the only products of metabolism are $\mathrm{CO}_{2}, \mathrm{H}_{2} \mathrm{O}$ and cell mass, and an inorganic nitrogen source is employed for growth. It is also assumed that at steady state, the rate of oxygen transfer from the bubbles is equal to the rate of oxygen uptake by the cells. Using these assumptions, the $k_{L} a$ value is calculated by setting these two oxygen rates equal, then the oxygen uptake rate is divided by the driving force of oxygen concentration, as shown in equation (2-13)

$$
k_{L} a=\frac{\mu X\left(K^{\prime} / Y o\right)}{\left(C^{*}-C_{L}\right)}
$$




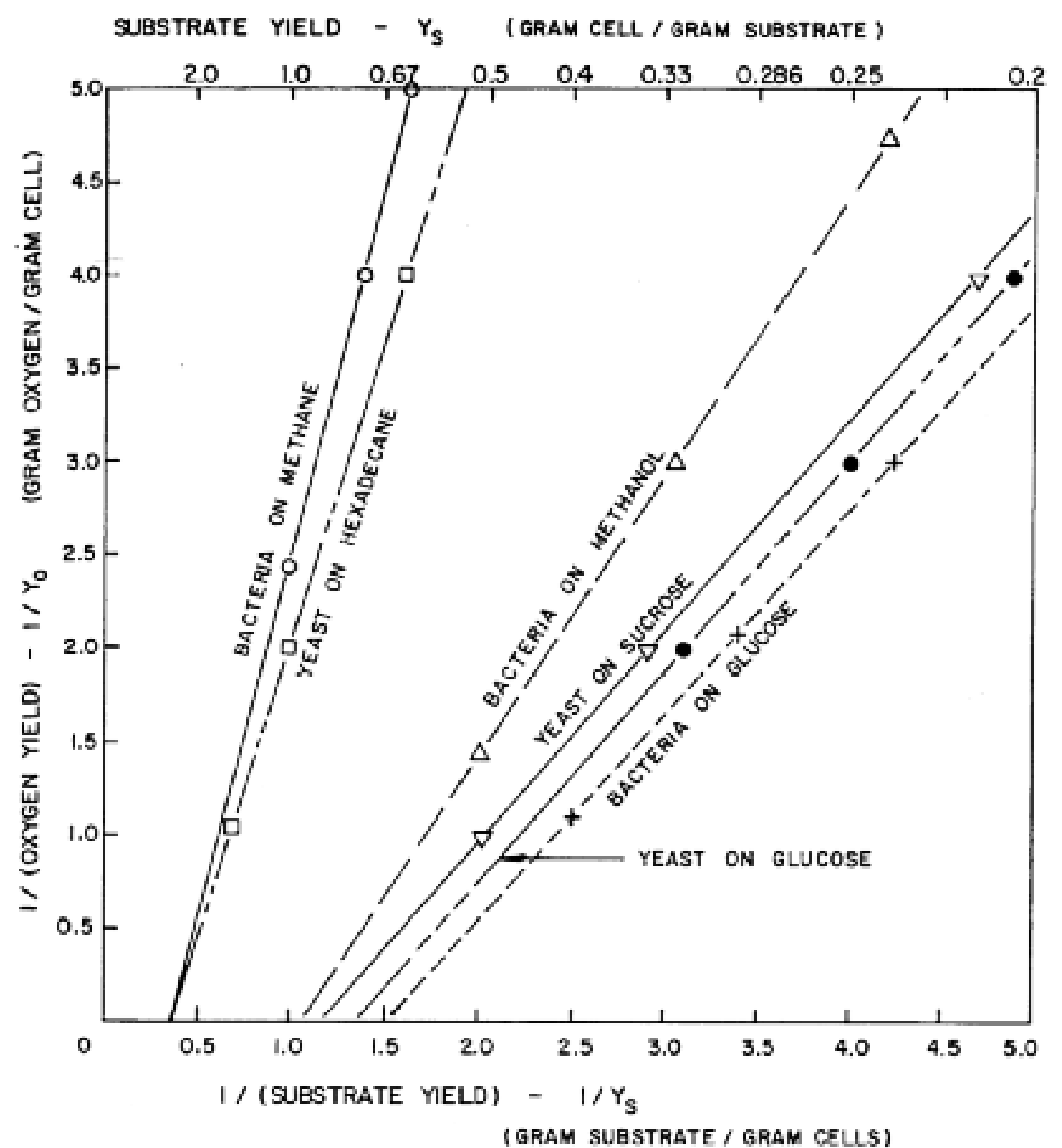

Figure 2.9. Relationship substrate yields and oxygen yields for different microorganisms grown on different substrates (Mateles, 1971) 


\subsubsection{Direct measurement method}

The direct measurement method uses an oxygen-balance technique to measure the oxygen transfer rate based on the difference in oxygen concentration in the air entering and exiting the fermenter. This oxygen balance technique determines directly the amount of oxygen transported into the broth. From a mass balance at steady state, the oxygen transfer rate can be determined from the equation (Wang et al, 1979):

$$
N_{A}=\left(7.32 \times 10^{5} / V_{L}\right)\left(Q_{i} P_{i} y_{i} / T i-Q_{o} P_{o} y_{o} / T_{o}\right)
$$

where

$V_{\mathrm{L}}=$ the volume of liquid in the fermenter $\left(\mathrm{m}^{3}\right)$,

$Q_{i}$ and $Q_{o}=$ the volumetric air flow rate measured at fermenter inlet and outlet $\left(\mathrm{L} \mathrm{min}^{-1}\right)$,

$P_{i}$ and $P_{o}=$ the total pressure measured at fermenter inlet and outlet (atm absolute),

$T_{i}$ and $T_{o}=$ the temperature of gas measured at fermenter inlet and outlet (K),

$y_{i}$ and $y_{o}=$ the mole fraction of oxygen measured at fermenter inlet and outlet $\left(\mathrm{mol} \mathrm{O}_{2} \mathrm{~mol}^{-1}\right)$, and

$7.32 \times 10^{5}=$ the conversion factor equaling $(60 \mathrm{~min} / \mathrm{h})[\mathrm{mol} / 22.41 \mathrm{~L}(\mathrm{STP})](273 \mathrm{~K} / 1 \mathrm{~atm})$

STP is standard temperature and pressure; T at $273 \mathrm{~K}, \mathrm{P}$ at $1 \mathrm{~atm}$.

$N A=$ the rate of oxygen transfer per unit volume of fluid $\left(\mathrm{mol} \mathrm{m}^{-3} \mathrm{~h}^{-1}\right)$,

To determine $k_{L} a$, the concentration of oxygen in the broth $(C)$ is measured in the fermenter. For small-scale fermenters, there is no problem in determining where in the fermenter to measure $C$, because the content is well mixed. $C^{*}$ is the equilibrium dissolved oxygen concentration at the outlet $\left(C^{*}{ }_{\text {out }}\right)$. The $k_{L} a$ value is calculated from the equation: 


$$
k_{L} a=N_{A} /\left(C^{*}{ }_{\text {out }}-C\right)
$$

For large-scale fermenters, $C$ is the average value of dissolved oxygen concentration measured at many positions in the fermenter. The $C^{*}$ measured at the gas outlet and gas inlet is different so a logarithmic mean value for the equilibrium dissolved oxygen concentration is used as shown:

$$
k_{L} a=N_{A} /\left(C^{*}-C\right)_{\log \text { mean }}
$$

and

$$
\left(C^{*}-C\right)_{\log \text { mean }}=\left(C^{*}{ }_{\text {in }}-C\right)-\left(C^{*}{ }_{\text {out }}-C\right) / \ln \left[\left(C^{*}{ }_{\text {in }}-C\right) /\left(C^{*}{ }_{\text {out }}-C\right)\right]
$$

where $C^{*}{ }_{i n}, C^{*}{ }_{\text {out }}$ are the equilibrium dissolved oxygen concentration at the gas inlet and gas outlet, respectively.

This method is the most reliable procedure for measuring $k_{L} a$, and allows determination from a single point measurement. The important advantage is that it can be applied to fermenters during normal operation. This method is the most accurate, but it requires accurate instrumentation for oxygen analysis, flow, pressure, and temperature measurements.

\subsection{Microbubble Dispersion}

Supplying surfactant-stabilized microbubble dispersion to growing yeast cultures for oxygen demand is an offshoot of early microbubble research by Sebba at Virginia Tech. These microbubbles were referred to as colloidal gas aphrons (CGA) to underscore properties of these small bubbles (Sebba, 1987). The initial CGA generator designed by Sebba was not able to supply large-scale production, thus he developed an improved spinning disc CGA generator. The term microbubble dispersion has been used instead of CGA because the generator produced a mixture of CGA-size bubbles (20-70 $\mu \mathrm{m})$ and large bubbles (3-5 mm) (Kaster, 1988). 


\subsubsection{History of Colloidal Gas Aphrons}

The production of microfoams by the Venturi method was first described by Sebba (1971) and the name has been changed to colloidal gas aphrons, or CGA because the bubbles are so small that they show some colloidal properties. The Venturi device for generating them was based upon rapid flow of the surfactant solution through a venturi throat, at which point air was admitted through a fine orifice (Figure 2.10). This method could produce a dispersion of bubbles which ranged from 25 to $50 \mu \mathrm{m}$ in diameter at a concentration which reached $65 \%$ by volume of gas in the water. However, the production was comparatively slow as it required recycling of the dispersion in order to build up the concentration. It also required a powerful pump to force the water through the venturi throat fast enough to entrain the gas bubbles. All those caused problems for scale-up.

In 1985, Sebba introduced an improved CGA generator design (Sebba, 1985), a spinning disc generator capable of producing about 4 liters of CGAs per minute. This device involved a horizontal disc that rotated very rapidly (above $4000 \mathrm{rpm}$ ) and was positioned about $2-3 \mathrm{~cm}$ below the surface of the surfactant solution and between two vertical baffles, as shown in Figure 2.11. If the disc rotated at less than about $4000 \mathrm{rpm}$, no CGA was formed, but once a critical speed was reached waves, were produced on the surface. These beat up against the baffles and have nowhere else to go, re-enter the liquid at the baffles. It was believed that the re-entering liquid carried with it a thin film of gas which become sandwiched between the liquid and the baffle. Such a thin film of gas was unstable and it would break up into minute droplets of gas encapsulated by the soapy shell, i.e. minute gas aphrons. 


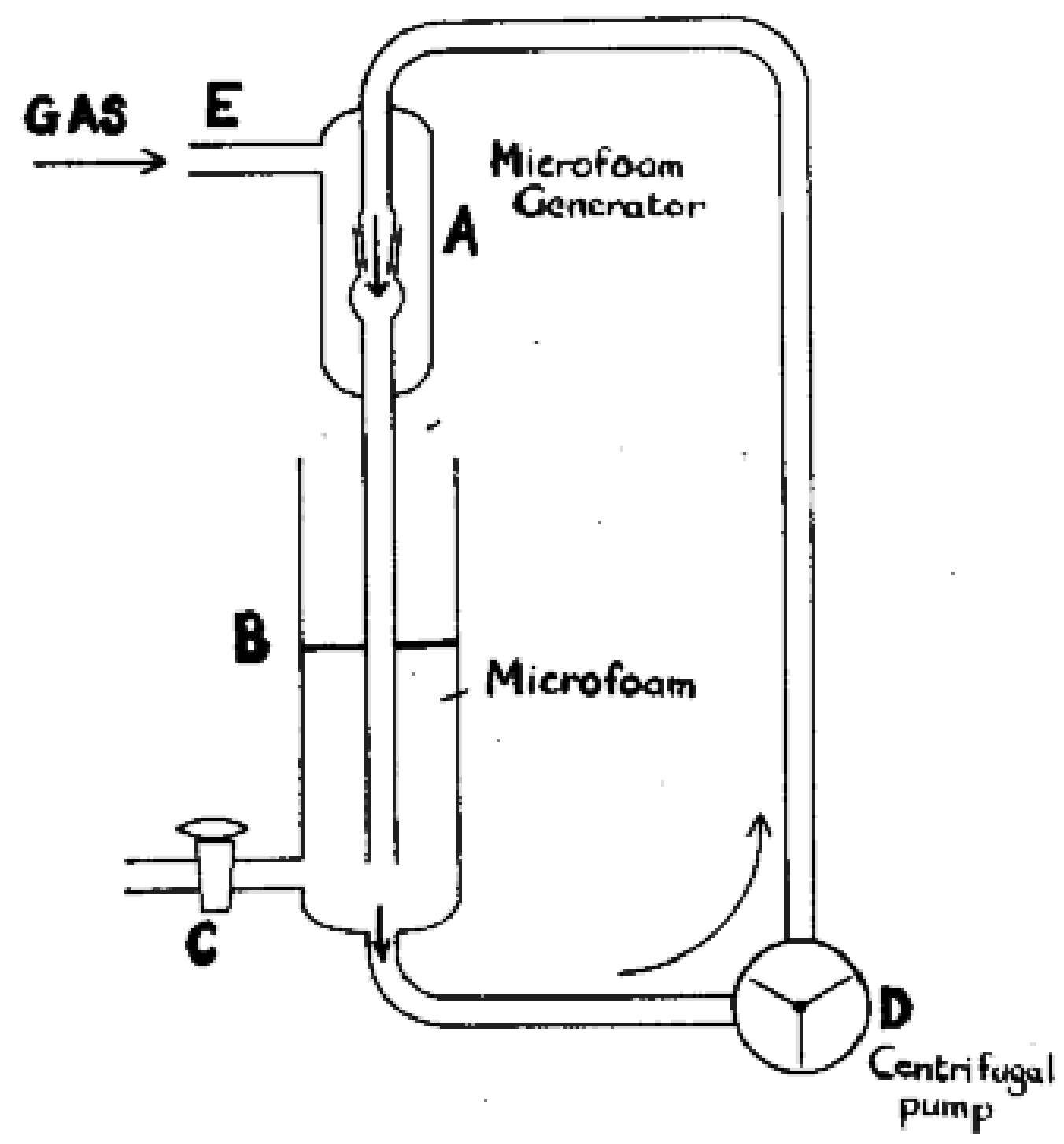

Figure 2.10. The microfoam generator (Sebba, 1971) 


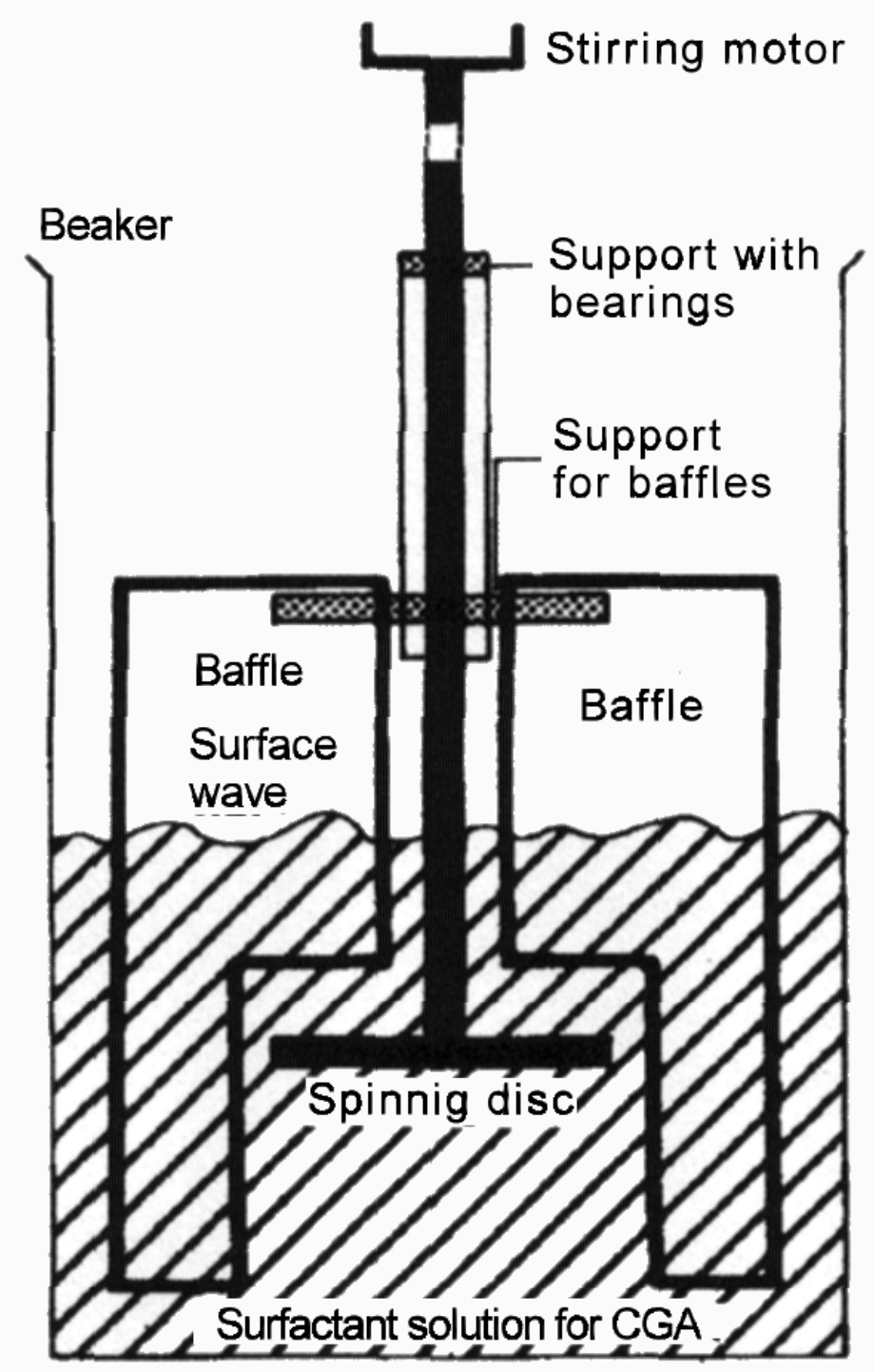

Figure 2.11. The spinning disk CGA generator (Sebba, 1985). 


\subsubsection{CGA Properties}

The structure of CGAs is often questioned and there have been no conclusive reports presented in the literature which consider this issue. Sebba postulated that they were composed of a gaseous inner core surrounded by a thin soapy film (Figure 2.12). A surfactant-stabilized shell of water was believed to lie between the gas phase and the surrounding bulk liquid phase. This shell has been likened to the liquid film that surrounds a soap bubble blown in air. The water in the shell had different properties from bulk water being more hydrogen bonded, and thus being a different phase from bulk water. This phase oriented surfactant molecules at the surface that are hydrophil pointing inwards and hydrophobe outwards. The surfactant molecules impart an electric double layer that reduces bubble coalescence by electrical repulsion of adjacent bubbles.

One of the properties of conventional foams, because of the elastic nature of the thin film lamella, is that they cannot easily be pumped through a tube and still retain their foam characteristics (Sebba, 1987). This restricts their possible applications considerably. The transportation difficulty does not occur with colloidal gas aphrons. The absence of CGA coalescence results in high stability and creates a system which flows as easily as does water. The facility with which these bubbles can be pumped from one vessel to another produces a system which has considerable potential in a remarkable diversity of applications.

Microbubbles (CGA) also have the potential to enhance mass transfer. The gas pressure inside a bubble is greater than that outside due to the surface tension. The magnitude of this

pressure differential, known as Laplace pressure, increases as the microbubbles shink (Rosen, 1989). Because the gas solubility is proportional to the pressure, the Laplace pressure increases the driving force for mass transfer. Additionally, microbubble mass transfer should be most effective for consumable gas, as the consumable gas is transferred into the liquid phase, the microbubble shrinks, further increasing the interfacial area per unit gas volume. 


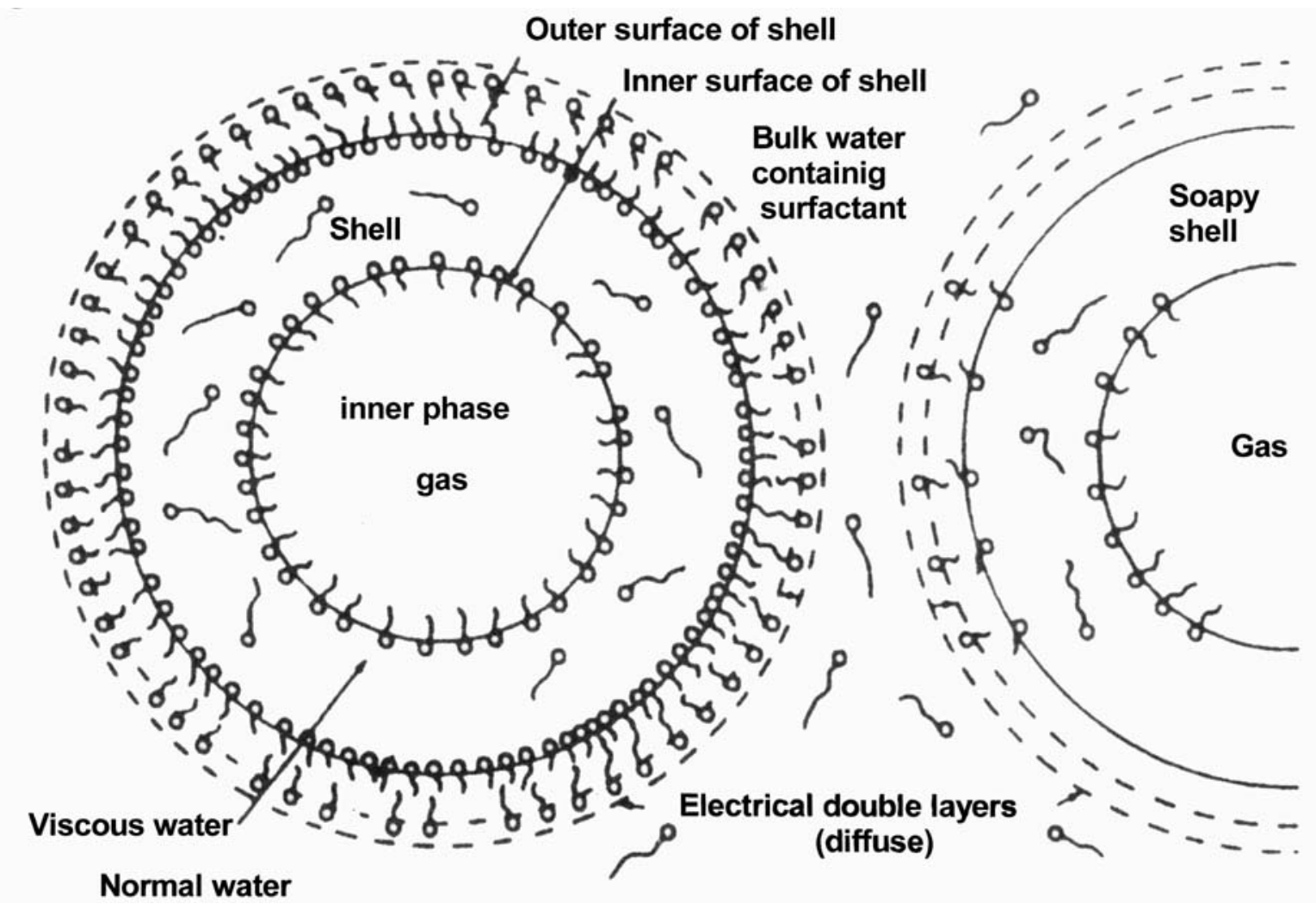

Figure 2.12. Structure of CGA proposed by Sebba. (Sebba, 1987) 
Chapalkar et al. (1994) reported that increasing surfactant concentration led to smaller diameter bubbles. Jauregi et al. (1997) found that higher concentrations of surfactant produced higher CGA stability. The repulsive forces between CGA were likely to increase as the concentration of surfactant increased either in the surfactant shell or in the bulk liquid phase, which led to more stable dispersions. The stability of bubbles decreased with increasing concentration of salt because the addition of salts or electrolytes would have an effect on the repulsive electrostatic interactions between charged aphrons. Increasing the concentration of salt would cause these interactions to be suppressed leading to the formation of a less stable dispersion. Jauregi et al. (1995) also reported that at low concentrations of surfactant, salt concentration had little effect on the CGA stability, but as surfactant concentration increased, the effect of the salt concentration also increased. Therefore, the maximum stability was obtained at the highest concentration of surfactant and lowest concentration of salt.

\subsubsection{Microbubble Dispersion in Fermentation}

There have been a number of reported applications for microbubble due to its specific characteristic, among which is fermentation. For an aerobic fermentation, oxygen transfer is the most important parameter. Sparingly dissolved oxygen is normally provided by sparging air into the reactor. However, much of the filtered air introduced into fermenter exits without contributing to the growth of microorganism, thus is wasted. Microbubbles properties provide a more efficient oxygen transfer over conventional air sparging.

Kaster et al. (1990) used microbubble dispersion to supply oxygen for Baker's yeast in a standard 2 L stirred tank fermenter. Growth rates of microorganisms were found to be equal or greater with MBD sparging than with air sparging. Hensirisak (1997) and Parasukulsatid (2000) also showed significant improvement in oxygen transfer to Saccharomyces cerevisiae cultures in scale-up of the reactor. Weber (2003) used microbubble dispersion to cultivate Trichoderma reesei for cellulose enzyme production. In an anaerobic fermentation, Bredwell and Worden (1998) applied the MBD to increase the mass transfer of synthesis gas to produce ethanol and butanol. 
The overall benefit of MBD to a fermentation process was in three ways. First, the small bubble has a small diameter resulting in large specific interfacial surface area, and thus, enhanced mass transfer. Second, small bubbles have a low rise velocity in the fermentation broth and therefore a longer bubble residence time. Third, MBD at relatively low agitation rate could achieve similar oxygen transfer as could be achieved with a high agitation rate in a conventional system, and hence less power required for the fermentation.

The fed-batch fermentation of recombinant HSA secreting $P$. pastoris is a high oxygen demand process for both the high cell density and secretion of the protein. The oxygen demand is usually met by increased agitation rate and use of oxygen-enriched air. However, high agitation rates subject microorganisms to high shear stress and caused high power consumption. High oxygen transfer efficiency of MBD sparging could point to a possible use of MBD as a viable oxygen source for fed-batch fermentation of $P$. pastoris, and thus reduce the power consumption and fermentation cost. 


\section{CHAPTER 3}

\section{MATERIALS AND METHODS}

\subsection{Organism and Storage}

The microorganism used in this study, Pichia pastoris GS115 His ${ }^{+} \mathrm{Mut}^{\mathrm{S}}$, was part of the Pichia Expression Kit (Invitrogen Corporation, Carlsbad, CA). The stock culture was maintained on YPD (1\% yeast extract, $2 \%$ peptone, $2 \%$ dextrose) agar medium at $4{ }^{\circ} \mathrm{C}$ and subcultured every two or three weeks to maintain viability.

\subsection{Inoculum Preparation}

Starter culture was prepared by transferring two loops of the stock culture into a $250 \mathrm{ml}$ Erlenmeyer flask containing $50 \mathrm{ml}$ of sterilized MGY [mix $100 \mathrm{ml}$ of sterile $1 \mathrm{M}$ potassium phosphate buffer (pH 6.0), $2 \mathrm{ml}$ filter sterilized solution of $20 \mathrm{mg} / 100 \mathrm{ml}$ biotin, $100 \mathrm{ml}$ filter sterilized solution of $13.4 \mathrm{~g} / 100 \mathrm{ml} \mathrm{YNB}$ (yeast nitrogen base without amino acid), and $100 \mathrm{ml}$ sterile solution of $10 \mathrm{~g} / 100 \mathrm{ml}$ glycerol] medium and incubated on a rotary platform shaker (New Brunswick Scientific, NJ) at $200 \mathrm{rpm}$ overnight at $30^{\circ} \mathrm{C}$.

\subsection{Fermentations}

\subsubsection{0 ml Fermentation with Conventional Sparging}

The $750 \mathrm{ml}$ working volume fermentation was conducted in a $1 \mathrm{~L}$ Biostat Q fermenter (B. Braun Biotech Inc., Allentown, PA). The vessel was temperature and $\mathrm{pH}$ controlled. The fermenter was filled with $450 \mathrm{ml}$ basal salts medium (Table 3.1 ) and $1.8 \mathrm{ml}$ filter sterilized trace salts solution (Table 3.2). The $\mathrm{pH}$ probe was calibrated before sterilization. The entire reactor assembly was sterilized at $121^{\circ} \mathrm{C}$ for $25 \mathrm{~min}$ in an 
Table 3.1. Basal Salts Solution

\begin{tabular}{cc}
\hline Component & Amount \\
\hline Phosphoric acid (85\%) & $26.7 \mathrm{ml}$ \\
Calcium sulfate & $0.93 \mathrm{~g}$ \\
$\mathrm{MnSO}_{4} \cdot \mathrm{H}_{2} \mathrm{O}$ & $14.9 \mathrm{~g}$ \\
Potassium sulfate & $18.2 \mathrm{~g}$ \\
Potassium hydroxide & $4.13 \mathrm{~g}$ \\
Glycerol & $40.0 \mathrm{ml}$ \\
\hline
\end{tabular}

*Add deionized water to make solution 1 liter.

Table 3.2. Trace Salts Solution

\begin{tabular}{cc}
\hline Component & Amount \\
\hline $\mathrm{CuSO}_{4} \cdot 5 \mathrm{H}_{2 \mathrm{O}}$ & $6.0 \mathrm{~g}$ \\
Sodium iodide & $0.08 \mathrm{~g}$ \\
$\mathrm{MnSO}_{4} \cdot \mathrm{H}_{2} \mathrm{O}$ & $3.0 \mathrm{~g}$ \\
Sodium molybdate & $20.2 \mathrm{~g}$ \\
Boric acid & $0.02 \mathrm{~g}$ \\
Cobalt chloride & $0.5 \mathrm{~g}$ \\
Zinc chloride & $20.0 \mathrm{~g}$ \\
FeSO & $\cdot 7 \mathrm{H}_{2} \mathrm{O}$ \\
Biotin & $6.5 \mathrm{~g}$ \\
Sulfuric acid & $0.2 \mathrm{~g}$ \\
\hline
\end{tabular}

*Add deionized water to make solution 1 liter. 
AMSCO sterilizer (Steris Corporation, Hicksville, NY). After sterilization, the medium was cooled to $30{ }^{\circ} \mathrm{C}$, and both the dissolved oxygen (DO) and the $\mathrm{pH}$ probe were recalibrated.

The fermentation medium was inoculated with $50 \mathrm{ml}$ starter culture (cell mass concentration $7.8 \mathrm{~g} / \mathrm{L}$ ). Fermentation was carried out at $30^{\circ} \mathrm{C}, \mathrm{pH} 5.80$, atmospheric pressure, and agitation rate of $500 \mathrm{rpm}, 750 \mathrm{rpm}$, and $1000 \mathrm{rpm}$. A constant $\mathrm{pH}$ was maintained by periodic automatic addition of $2.3 \mathrm{M}$ ammonium hydroxide solution or $0.5 \mathrm{M} \mathrm{HCl}$. Air flow rate was fixed at $1 \mathrm{~L} / \mathrm{min}$, but the equivalent volume of air per volume of medium per minute (vvm) varied because of the fed-batch addition of nutrients. However, the process was identical for each batch. The DO level was not controlled but was allowed to fall freely until equilibrium level was established. $0.2 \mathrm{ml}$ antifoam 204 (Sigma, MO) was initially added to the fermenter.

After 24 hours of batch fermentation, addition of glycerol feed (150 ml $50 \%$ glycerol + $1.8 \mathrm{ml}$ trace salt solution) was started. The feed rate was $12.5 \mathrm{ml} / \mathrm{h}$ and feeding was stopped after $12 \mathrm{~h}$. Glycerol feed was stopped for 1 hour (between $36 \mathrm{~h}$ and $37 \mathrm{~h}$ ) to starve the cells. After the starvation period, addition of methanol feed $(142 \mathrm{ml} 50 \%$ methanol $+1.7 \mathrm{ml}$ trace salts solution) was started at $1.1 \mathrm{ml} / \mathrm{h}$. The methanol was fed at $1.1 \mathrm{ml} / \mathrm{h}$ for 12 hours, and then the feed rate was increased to $2.7 \mathrm{ml} / \mathrm{h}$ for 48 hours. The total fermentation time was 97 hours.

$5 \mathrm{ml}$ culture broth was taken every 12 hours throughout the whole fermentation run. 1.5 $\mathrm{ml}$ sample culture broth was diluted with $1.5 \mathrm{ml} 0.1 \mathrm{M}$ acetate buffer $(\mathrm{pH} 4.0)$ to dissolve the precipitated salts in the medium. The cell mass concentrations were measured spectrophotometrically at $600 \mathrm{~nm}$ using Spectronic 1001 instrument (Milton Roy Company, Rochester, NY). The DO levels were recorded manually every 12 hours. Culture samples were centrifuged at $20,000 \times \mathrm{g}$ for $10 \mathrm{~min}$ and supernatants were collected and stored in $\mathrm{a}+2{ }^{\circ} \mathrm{C}$ refrigerator for further protein analysis.

\subsubsection{L Fermentation with Conventional Sparging}

The 1-L working volume fermentation was conducted in a 1.6-L bench top Bioflo III fermenter (New Brunswick Scientific, NJ). The vessel was equipped with $\mathrm{pH}$, dissolved oxygen (DO), and temperature probes controlled by a proportional / integral / derivative (PID) controller. The addition of acids, bases, and nutrients were controlled from the module. The fermenter was 
initially filled with $550 \mathrm{ml}$ basal salts media and $\quad 2.2 \mathrm{ml}$ filter sterilized trace salts solution. The $\mathrm{pH}$ probe was calibrated before the sterilization. The entire vessel was sterilized at $121{ }^{\circ} \mathrm{C}$ for $25 \mathrm{~min}$ in the autoclave. After sterilization, the medium was cooled to $30{ }^{\circ} \mathrm{C}$ and both the DO and the $\mathrm{pH}$ probes were recalibrated.

The medium was inoculated with $50 \mathrm{ml}$ of starter culture (cell mass concentration $7.8 \mathrm{~g} /$ L) was added to the medium. Fermentation was carried out at $30^{\circ} \mathrm{C}, \mathrm{pH} 5.80$, atmospheric pressure, and agitation rates were set at $350 \mathrm{rpm}, 500 \mathrm{rpm}$, and $750 \mathrm{rpm}$. Similarly, $2.3 \mathrm{M}$ ammonium hydroxide solution or $0.5 \mathrm{M} \mathrm{HCl}$ was automatically added to keep constant $\mathrm{pH}$. Air flow rate was fixed at $1 \mathrm{~L} / \mathrm{min}$ as described previously. The DO level was not controlled, but was allowed to fall freely until equilibrium level was established. $0.25 \mathrm{ml}$ antifoam 204 (Sigma, MO) was initially added to the fermenter.

After 24 hours of batch fermentation, addition of glycerol feed $(183.3 \mathrm{ml} 50 \%$ glycerol + $2.2 \mathrm{ml}$ trace salt solution) was started. The feed rate was $15.3 \mathrm{ml} / \mathrm{h}$ and feeding was stopped after $12 \mathrm{~h}$. Similar to the $750 \mathrm{ml}$ fermentation, glycerol feed was stopped for 1 hour (between 36 $\mathrm{h}$ and $37 \mathrm{~h}$ ) to starve the cells. After the starvation period, addition of methanol feed (173 $\mathrm{ml} 50$ $\%$ methanol $+2.1 \mathrm{ml}$ trace salts solution) was started at a feed rate of $1.4 \mathrm{ml} / \mathrm{h}$. The methanol was fed at $1.4 \mathrm{ml} / \mathrm{h}$ for 12 hours and then the feed rate was increased to $3.2 \mathrm{ml} / \mathrm{h}$ for the last 48 hours. The total fermentation time was 97 hours.

Culture broth sampling and DO level recording were the same as previously described in the $750 \mathrm{ml}$ fermentation.

\subsubsection{L Fermentation with Microbubble Disperion Sparging}

For the microbubble dispersion experiments, the fermentation conditions were the same as the $1 \mathrm{~L}$ conventional fermentation except that a microbubble dispersion (MBD) generator was used to supply air instead of the normal air supply after 24 hours of fermentation. To maintain the broth volume in the fermenter, the MBD generator was 


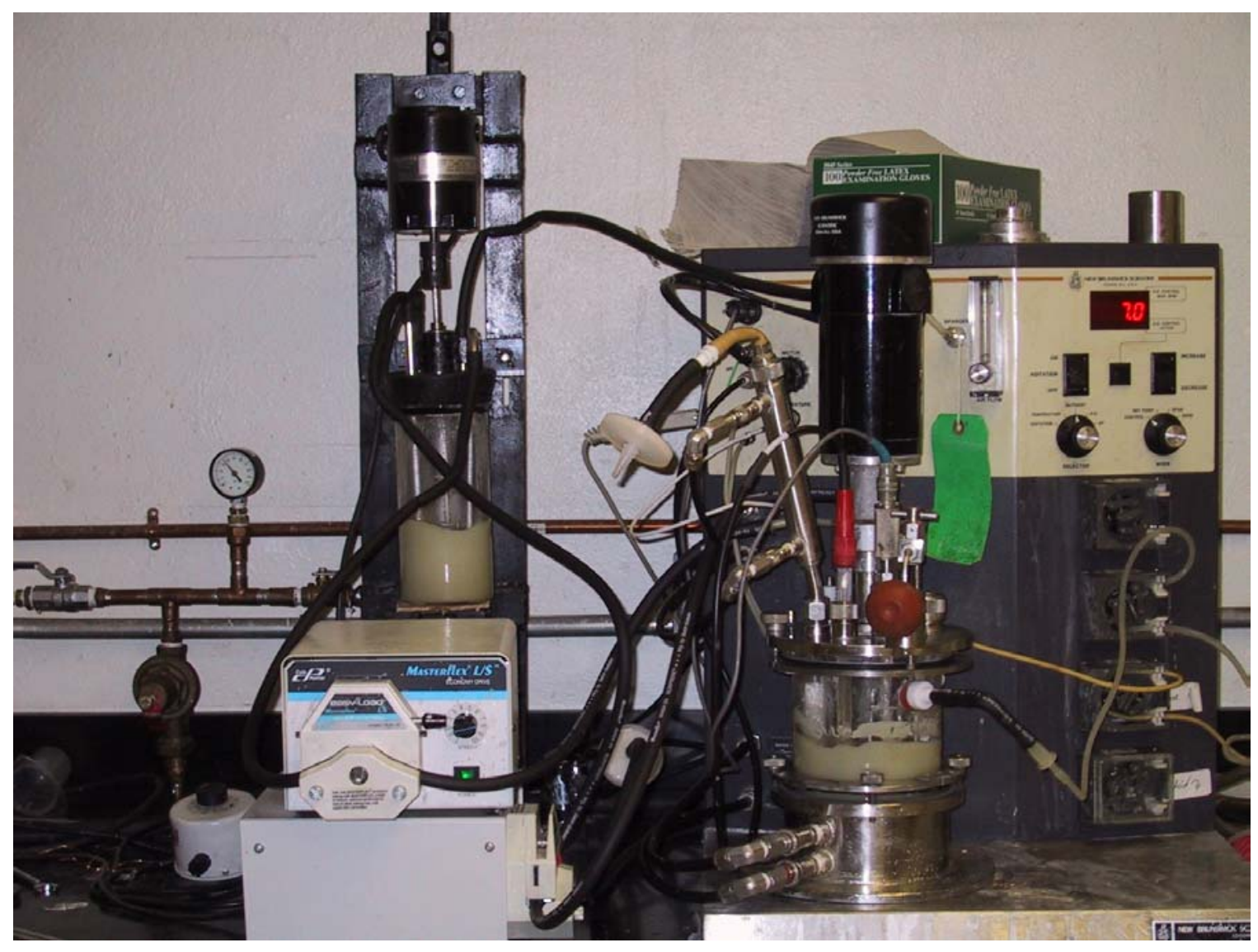

Figure 3.11 liter fermentation with microbubble dispersion unit 
filled with $400 \mathrm{ml}$ sterilized basal salts solution. The entire unit of the MBD generator connected to the $1.6 \mathrm{~L}$ bench top Bioflo III fermenter was sterilized in the autoclave at $121{ }^{\circ} \mathrm{C}$ for $25 \mathrm{~min}$. The experimental set-up for a MBD experiment is shown in Figure 3.1. The peristaltic recycle pump was used to transfer the fermentation broth to the MBD generator at approximately $40 \mathrm{ml} /$ min. The agitation speed of the MBD generator was set at $4000 \mathrm{rpm}$ to create the microbubble dispersion. The microbubble dispersion stabilized by natural surfactant secreted by microorganisms was delivered by the peristaltic pump at $100 \mathrm{ml} / \mathrm{min}$ back to the fermenter sparger. Nutrients supply and feed rates were the same as described in the 1 L conventional fermentation.

The fermentation broth was sampled at similar intervals as that for the $1 \mathrm{~L}$ air-sparged fermentation. All samples were analyzed for cell mass and protein concentrations. DO levels were recorded manually every 12 hours.

\subsection{Assays}

\subsubsection{Cell Mass Concentration}

Biomass concentration (grams of dry cell per liter) was determined from the optical density (OD) at $600 \mathrm{~nm}$ on a Spectronic 1001 spectrophotometer. $1.5 \mathrm{ml}$ Culture broth sample was diluted with $1.5 \mathrm{ml} \mathrm{0.1} \mathrm{M}$ acetate buffer ( $\mathrm{pH} \mathrm{4.0)}$ ) to dissolve the precipitated salts in the medium. After the OD values were measured, samples were transferred into $2 \mathrm{ml}$ centrifuge tubes and centrifuged at $20,000 \times g$ for $10 \mathrm{~min}$. The cells were decanted, washed, recentrifuged and decanted again. The washed samples were dried at $80{ }^{\circ} \mathrm{C}$ for $24 \mathrm{~h}$ to a constant mass and weighed. The OD and gravimetric data were used to develop a calibration curve for all the runs. The curve was linear within OD values of 0 to 1.0 , with $\mathrm{R}^{2}$ equal to 0.9909 . When $\mathrm{OD}$ values exceeded 1.0 absorbance unit, the samples were diluted to fit the calibration range and the corresponding cell mass concentration was multiplied by the dilution factor. 


\subsubsection{Glycerol Concentration}

The concentration of glycerol in the fermentation broth was determined by high performance liquid chromatography (HPLC). A $300 \mathrm{~mm} \times 7.8 \mathrm{~mm}$ stainless steel BP-100 H${ }^{+}$ Carbohydrate column (Benson Polymeric Inc, Reno, NV) set in the Shimadzu LC-10AD VP (Shimadzu Scientific Instruments Inc, Columbia, MD) was used for the analysis. $2.5 \mathrm{mM} \mathrm{H}_{2} \mathrm{SO}_{4}$ solution was used as the mobile phase at a flow rate of $0.4 \mathrm{ml} / \mathrm{min}$. Standard glycerol solutions were prepared in concentrations of $1,3,5,8,10 \mathrm{~g} / \mathrm{L}$. A $10 \mu \mathrm{l}$ sample volume was injected into the column. The plot of glycerol concentration versus peak area was linear with $\mathrm{R}^{2}$ equal to 0.9998. To determine the glycerol concentration in the fermentation broth, $1.5 \mathrm{ml}$ sample was centrifuged at $20,000 \times g$ for $10 \mathrm{~min}$ and decanted. The collected supernatant was then filtered through a $0.2 \mu \mathrm{m}$ filter before injection into the HPLC column. The glycerol content of the supernatant solution was calculated using the calibration curve determined above. When glycerol concentrations exceeded $10 \mathrm{~g} / \mathrm{L}$, the samples were diluted to fit the calibration range and the corresponding glycerol concentration was multiplied by the dilution factor.

\subsubsection{Methanol Concentration}

The concentration of methanol in the fermentation broth was also determined by HPLC. The same stainless steel BP-100 $\mathrm{H}^{+}$Carbohydrate column set in the Shimadzu LC-10AD VP was used for analysis. Similarly $2.5 \mathrm{mM} \mathrm{H}_{2} \mathrm{SO}_{4}$ solution was used as the mobile phase at a flow rate of $0.4 \mathrm{ml} / \mathrm{min}$. Standard methanol solutions were prepared in concentrations of 5, 10, 15, 20, $25 \mathrm{~g} / \mathrm{L}$. A $10 \mu \mathrm{l}$ sample volume was injected into the column. The plot of methanol concentration versus peak area was linear with $\mathrm{R}^{2}$ equal to 0.9996 . To determine the methanol concentration in the fermentation broth, $1.5 \mathrm{ml}$ sample was centrifuged at $20,000 \times g$ for $10 \mathrm{~min}$ and decanted. The supernatant was then filtered through a $0.2 \mu \mathrm{m}$ filter before injection into the HPLC column. The methanol content of the supernatant solution was calculated using the calibration curve determined above. When methanol concentrations exceeded $25 \mathrm{~g} / \mathrm{L}$, the samples were diluted to fit the calibration range and the corresponding methanol concentration was multiplied by the dilution factor 


\subsubsection{Determination of the $k_{L} a$ values}

The volumetric oxygen transfer coefficient $\left(k_{L} a\right)$ was determined by the yield coefficient method (Wang et al, 1979). At steady state, the oxygen uptake rate by the cells is equal to the oxygen transfer rate. The $k_{L} a$ value was then calculated from this assumption (see details in section 2.4.3) and shown below:

$$
k_{L} a=\frac{\mu \mathrm{X}\left(\mathrm{K}^{\prime} / \mathrm{Y}_{\mathrm{O}}\right)}{\left(C^{*}-C\right)}
$$

where

$$
\begin{aligned}
& k_{L} a=\text { volumetric oxygen transfer coefficient }\left(\mathrm{h}^{-1}\right), \\
& \mu=\text { specific growth rate }\left(\mathrm{h}^{-1}\right), \\
& X=\text { cell mass }\left(\mathrm{g} \mathrm{L}^{-1}\right), \\
& K^{\prime}=\text { conversion factor }=31.25\left(\mathrm{mmol} \mathrm{O}_{2} \mathrm{~g} \mathrm{O}_{2}^{-1}\right), \\
& Y o=\text { yield coefficient on oxygen }\left(\mathrm{g} \text { cell mass g O} \mathrm{O}_{2}^{-1}\right), \\
& C^{*}=\text { saturated dissolved oxygen concentration }\left(0.236 \mathrm{mmol} \mathrm{O}_{2} \mathrm{~L}^{-1}\right) \text {, and } \\
& C=\text { dissolved oxygen concentration }\left(\mathrm{mmol} \mathrm{O}_{2} \mathrm{~L}^{-1}\right) .
\end{aligned}
$$

The values of $Y o$ were calculated from the glycerol and cell stoichiometric relationships and glycerol yield coefficients. A generalized method for calculating the oxygen yield coefficient was shown by Mateles (1971) to be

$$
\frac{1}{Y o}=\frac{g O_{2}}{\text { gcells }}=16\left[\frac{2 C+H / 2-O}{Y s M}+\frac{O^{\prime}}{1600}-\frac{C^{\prime}}{600}+\frac{N^{\prime}}{933}-\frac{H^{\prime}}{200}\right]
$$

where

$Y o=$ oxygen yield coefficient in $\mathrm{g}$ cells $/ \mathrm{g} \mathrm{O}_{2}$,

$\mathrm{C}, \mathrm{H}, \mathrm{O}=$ number of atoms of carbon, hydrogen and oxygen in the glycerol, with $\mathrm{C}=3, \mathrm{H}=$ $8, \mathrm{O}=3$ 
$Y_{S}=$ glycerol yield coefficient in $\mathrm{g}$ cells/g glycerol

$\mathrm{M}=$ molecular weight of glycerol, with $\mathrm{M}=92$

$\mathrm{O}^{\prime}, \mathrm{C}^{\prime}, \mathrm{N}^{\prime}, \mathrm{H}^{\prime}=$ percent of oxygen, carbon, nitrogen, and hydrogen in the cell, respectively, here typical yeast composition was used for calculation, with $\mathrm{O}^{\prime}=31, \mathrm{C}^{\prime}=47, \mathrm{~N}^{\prime}=7.5, \mathrm{H}^{\prime}=$ 6.5 .

To find $Y o, Y_{s}$ had to be determined first. Cell mass concentration at time 0 and $36 \mathrm{~h}$ were calculated (see details in section 3.4.1). The cell mass concentration at $36 \mathrm{~h}$ subtracted from the cell mass concentration at time 0 was equal to $X$. Glycerol concentrations at time $0 \mathrm{~h}$ and $36 \mathrm{~h}$ were determined (see details at section 3.4.2). Thus, glycerol yield coefficient could be calculated. The dissolved oxygen concentration (C) was determined from the DO value (\% saturation dissolved oxygen) interpolated with the DO value at $100 \%$. The $100 \%$ DO was assumed to be the same as that in pure water at $30^{\circ} \mathrm{C}$ of $0.236 \mathrm{mmol} / \mathrm{L}$, which was good enough for $k_{L} a$ comparison between different systems.

\subsubsection{Protein Concentration}

Because Pichia pastoris secretes only low levels of endogenous proteins, a secreted heterologous protein comprises the vast majority of the total protein in the medium (Cregg, 1998). Concentration of extracellular protein produced by $P$. pastoris can be estimated by using a Lowry type of protein analysis on trichloroacetic acid solution (TCA) precipitated material (Klaus, 1995). Indirect Lowry procedure with protein precipitation, which used deoxycholate (DOC) and TCA, was performed after each run using protein assay kit (Sigma Chemical Company, MO).

One milliliter supernatant solution of the centrifuged fermentation broth was added to a micro-centrifuge tube. About $0.1 \mathrm{ml}$ DOC solution was added into the centrifuge tube, mixed well on Fisher Vortex Genie 2 (Fisher Scientific, PA), and was allowed to stand at room temperature for $10 \mathrm{~min}$. TCA solution $(0.1 \mathrm{ml})$ was added and mixed well. The whole solution was centrifuged at $20,000 \times g$ for 5 min to pelletize the precipitates. The supernatant was decanted and discarded. The pellet was dissolved in $1 \mathrm{ml}$ of Lowry Reagent and then transferred 
to an appropriately labeled test tube. The centrifuge tube was rinsed with $1 \mathrm{ml}$ of DI water and added to the test tube. The solution was allowed to stand at room temperature for $20 \mathrm{~min} .0 .5 \mathrm{ml}$ Folin agent was added into the test tube and allowed to develop color for $30 \mathrm{~min}$. The absorbance of the solution was measured spectrophotometrically at $700 \mathrm{~nm}$ using Spectronic 1001 instrument. Standard bovine serum albumin solution prepared in concentrations of $10 \mathrm{mg} / \mathrm{L}, 20$ $\mathrm{mg} / \mathrm{L}, 30 \mathrm{mg} / \mathrm{L}, 40 \mathrm{mg} / \mathrm{L}, 50 \mathrm{mg} / \mathrm{L}, 100 \mathrm{mg} / \mathrm{L}, 200 \mathrm{mg} / \mathrm{L}, 300 \mathrm{mg} / \mathrm{L}$, and $400 \mathrm{mg} / \mathrm{L}$ was used to develop a calibration curve. The protein concentration in the culture sample was then determined from a linear calibration curve described above with $\mathrm{R}^{2}$ equal to 0.9785 .

\subsubsection{Protein analysis}

Sodium Dodecylsulfate Polyacrylamide Gel Electrophoresis (SDS-PAGE) was used to determine the molecular weight of the protein and to assess the degradation of the protein. The PAGEr Gold Precast 10-20\% Tris-Glycine gel (Cambrex Bio Science Rockland Inc, Rockland, ME) was assembled to the Xcell SureLock ${ }^{\mathrm{TM}}$ Mini-Cell (Invitrogen Corporation, Carlsbad, CA) to perform the electrophoresis. About $25 \mu \mathrm{l}$ reducing sample buffer and $25 \mu \mathrm{l}$ biopure water were added to $50 \mu \mathrm{l}$ protein sample in a micro-centrifuge tube to make $100 \mu \mathrm{l}$ sample solution. The sample solution was boiled for 5 minutes and pulsed on Fisher Vortex Genie 2 for 30 seconds. 10 $\mu 1$ sample from each tube was loaded into a well. SDS-PAGE molecular weight standards (Bio-

Rad Laboratories, Hercules, CA) contained Phosphorylase b (97 kD), Bovine Serum albumin (67 $\mathrm{kD})$, Ovalbumin (45 kD), Carbonic anhydrase (31 kD), Soybean trypsin inhibitor (21 kD), and Lysozyme (14 kD). $400 \mu \mathrm{g}$ of each standard protein was contained in $200 \mu$ l concentrated solution. About $25 \mu \mathrm{l}$ reducing sample buffer and $25 \mu \mathrm{l}$ biopure water were added to $50 \mu 1$ standard protein solution in a micro-centrifuge tube to make $100 \mu 1$ standard solution. The standard solution was loaded to the first well for comparison. The gel was run at $200 \mathrm{~V}$ for approximately 1 hour.

The gel was placed in a scrupulously clean staining tray. Staining procedure was conducted using Silver Stain Plus Kit (Bio-Rad Laboratories, Hercules, CA). The whole procedure included fixative step-20 min, rinse step-20 min, staining and developing step-20 min, and stop step-15 min. After stopping the reaction the gel was rinsed in high purity water for 5 minutes and then it was ready to be photographed. 


\section{CHAPTER 4}

\section{RESULTS AND DISCUSSION}

\subsection{Conventionally Sparged Fermentations}

Conventionally sparged $P$. pastoris fermentations were conducted in the 1.6-L Bioflo III fermenter at agitation rate of $350 \mathrm{rpm}, 500 \mathrm{rpm}, 750 \mathrm{rpm}$. Kobayashi et al. (2000) reported that the protein production reached its maximum at $96.5 \mathrm{~h}$ of cultivation. To determine the optimal fermentation length so that maximal amount of protein could be obtained without further incubation, 121 hours of conventionally sparged fermentation was conducted in the 1.6-L Bioflo III fermenter at agitation rate of $350 \mathrm{rpm}$. The $\mathrm{pH}$ and temperature of fermentation medium were maintained at 5.80 and $30{ }^{\circ} \mathrm{C}$, respectively.

The fed-batch high cell density fermentation was designed such that cell growth on glycerol feeding could be very fast under conditions of high concentrations of selected mineral salts continuously fed to the fermenter. As the cell density got relatively higher, the energy needed for growth got higher, and thus, higher oxygen transfer was needed. The cell growth on methanol feeding was very slow, but the secretion of the protein to the fermentation broth was an energy consuming process which also required high levels of oxygen.

\subsubsection{Conventionally Sparged Fermentation at 350 rpm}

The cell growth pattern, protein production pattern, and dissolved oxygen profile are shown in Figure 4.1. There seemed to be no lag phase at the beginning of the cell growth. The cell growth curve showed that there was a slight rapid period of cell growth followed by a slower phase. The cell mass concentration of $27.95 \mathrm{~g} / \mathrm{L}$ at the end of the fermentation was very low because of the poor oxygen transfer at the relatively low agitation rate, as shown by the rapid decrease in dissolved oxygen to zero after $36 \mathrm{~h}$ of fermentation (Figure 4.1). 


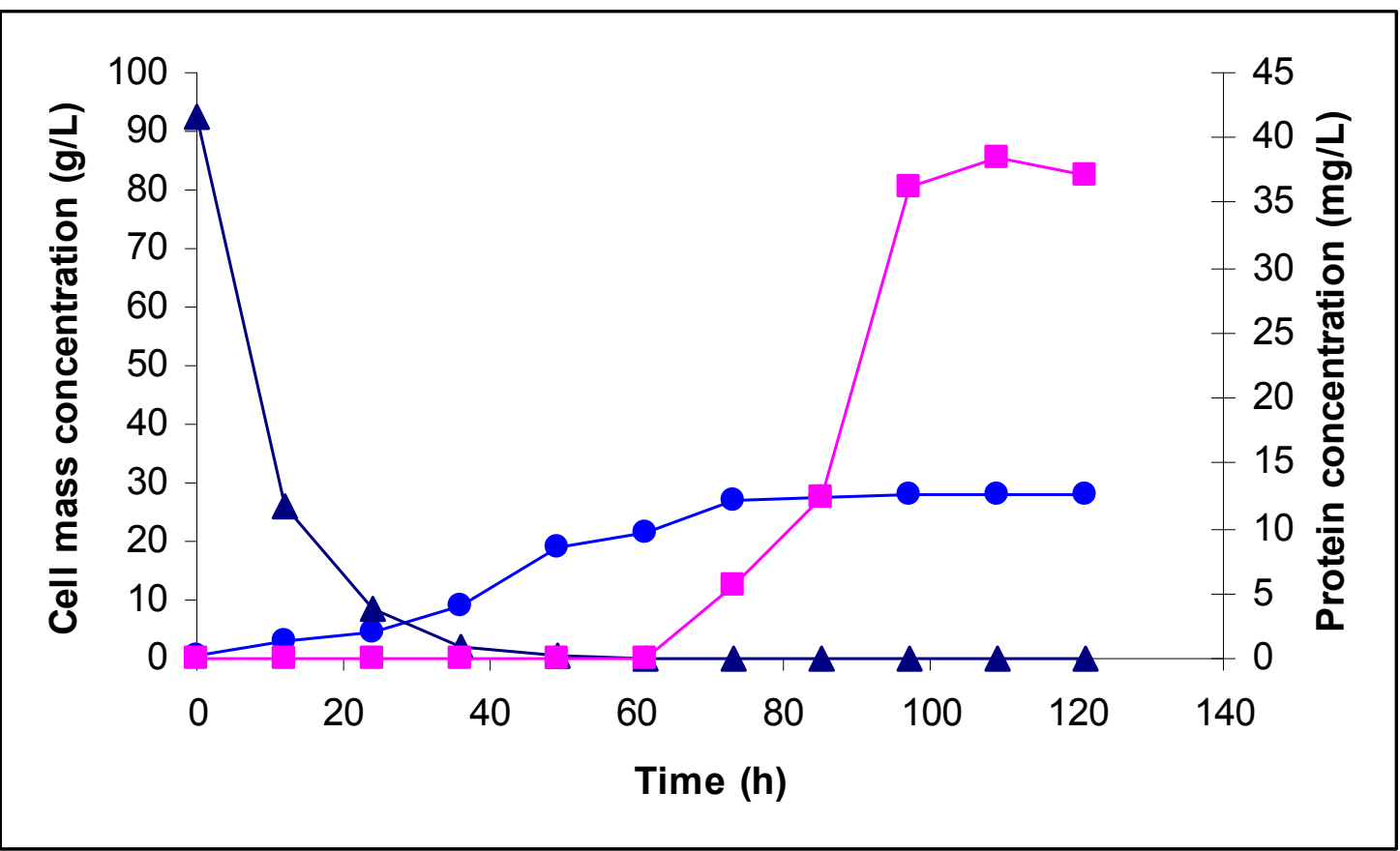

Figure 4.1 Conventional fermentation at $350 \mathrm{rpm}$

Cell mass concentration $(\bullet)$

Protein concentration $(\square)$

Dissolved oxygen $(\boldsymbol{\Delta})$

Due to the oxygen limitation, protein production was also poor. Protein was produced in the fermentation broth after $61 \mathrm{~h}$, with a concentration of $5.52 \mathrm{mg} / \mathrm{L}$ at $73 \mathrm{~h}$. Protein concentration started to increase rapidly, from this point to $36.29 \mathrm{mg} / \mathrm{L}$ at $97 \mathrm{~h}$. After $97 \mathrm{~h}$ of fermentation the protein production plateaued at $37.11 \mathrm{mg} / \mathrm{L}$.

The focus of this study was to demonstrate the feasibility and benefits of microbubble sparged $P$. pastoris fermentations. Therefore, 97 hour was chosen as a suitable period of time for all the fermentation runs to compare the cell growth and protein production between different systems. 


\subsubsection{Conventionally Sparged Fermentation at 500 rpm}

When the agitation rate was increased to $500 \mathrm{rpm}$, the improved oxygen transfer is shown in Figure 4.2. Cell mass concentration at $500 \mathrm{rpm}$ was $48.98 \mathrm{~g} / \mathrm{L}$, almost double that at $350 \mathrm{rpm}$ agitation. The increased cell mass concentration was associated with the improved DO level in the system. Dissolved oxygen dropped gradually as the growing cell concentration got higher. The decrease in the dissolved oxygen in the $500 \mathrm{rpm}$ fermentation was not as sharp as in the 350 rpm fermentation, although it still dropped to almost zero at the end of the fermentation.

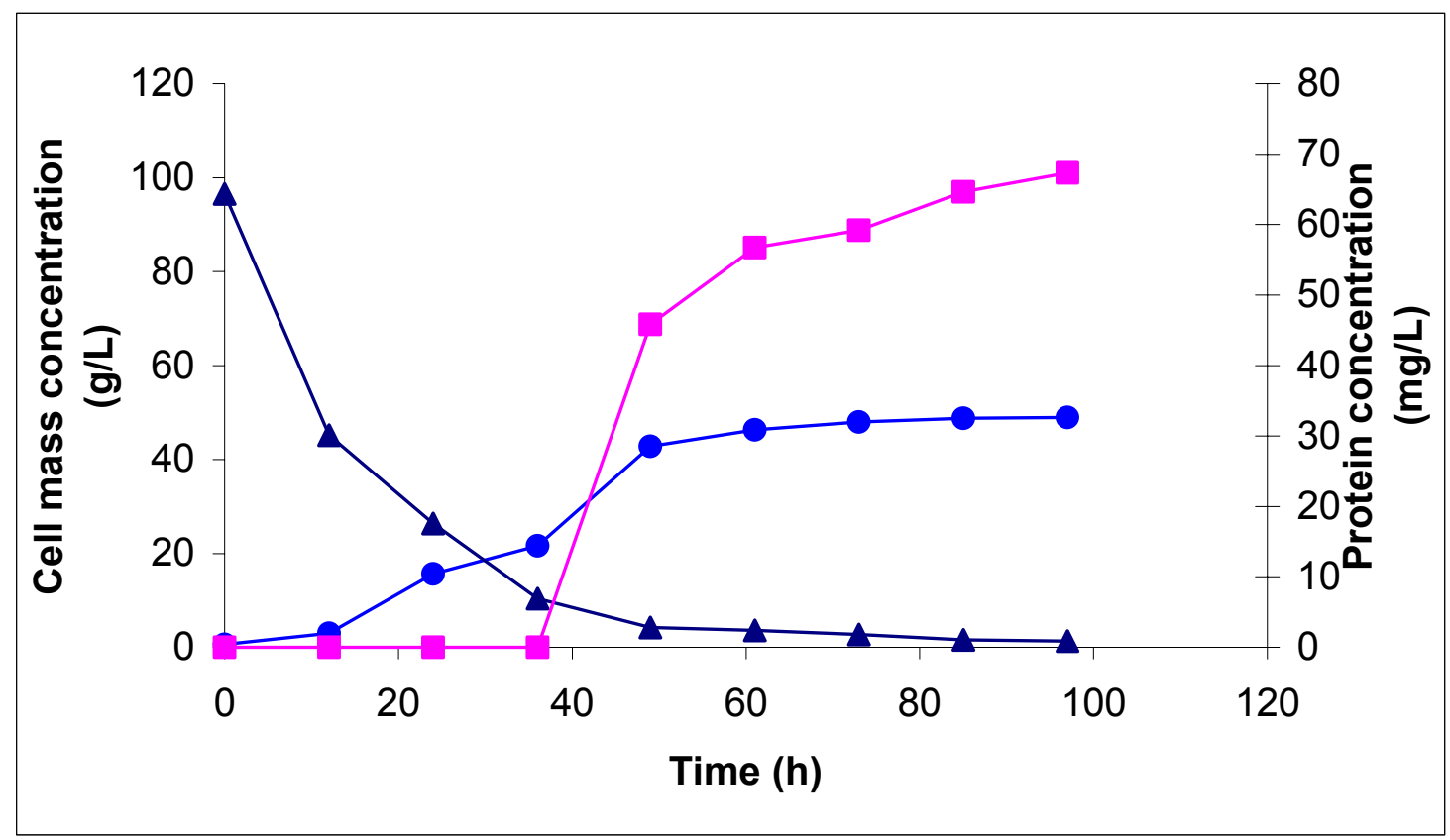

Figure 4.2 Conventionally sparged fermentation at $500 \mathrm{rpm}$

Cell mass concentration $(\bullet)$

Protein concentration $(\mathbf{\square})$

Dissolved oxygen $(\boldsymbol{\Delta})$

With the improved oxygen transfer, the protein production was much better than that at $350 \mathrm{rpm}$. Protein started to be produced after $37 \mathrm{~h}$, and protein concentration reached $67.34 \mathrm{mg} /$ $\mathrm{L}$ at the end of fermentation run, which was also about 2.0 times higher than that in the $350 \mathrm{rpm}$ fermentation. When the microorganism started to metabolize methanol, the protein production 
started. The secretion of the protein into the fermentation broth requires oxygen to provide energy. Therefore, better oxygen transfer at $500 \mathrm{rpm}$ improved protein production. The doubling of the protein concentration at the end of $500 \mathrm{rpm}$ fermentation compared to that in the $350 \mathrm{rpm}$ fermentation was also because of the increased cell mass concentration achieved at $500 \mathrm{rpm}$.

\subsubsection{Conventionally Sparged Fermentation at 750 rpm}

High agitation rate of $750 \mathrm{rpm}$ fermentation was conducted in the conventionally sparged system to see the effect of more efficient oxygen transfer on the cell production and protein production. At this very high agitation rate, a high cell density of $138.2 \mathrm{~g} / \mathrm{L}$ was achieved due to sufficient oxygen dispersion in the fermentation medium (Figure 4.3). Cell growth was very fast during the first 49 hours, increasing rapidly to $109.8 \mathrm{~g}$ / L at $49 \mathrm{~h}$. From $49 \mathrm{~h}$, cell growth rate slowed down, gradually to the cell mass concentration of 138.2 at $97 \mathrm{~h}$.

The higher cell concentration at $750 \mathrm{rpm}$ agitation resulted in a much better protein production at high agitation rate of $750 \mathrm{rpm}$. Protein production started after $37 \mathrm{~h}$. The initial protein concentration measured at $49 \mathrm{~h}$ was $107.4 \mathrm{mg} / \mathrm{L}$ (Figure 4.3), and this increased to $317.9 \mathrm{mg} / \mathrm{L}$ after $97 \mathrm{~h}$. The level of protein concentration was similar to that reported by Kobayashi et al. (2000). The improved protein production was also attributed to the more efficient oxygen delivery to the microorganisms. The dissolved oxygen profile showed that the DO decreased much slower than those at lower agitation rates (Figure 4.1 - 4.2). The fermentation stage after 24 hours was a high oxygen utilization process, and DO level dropped rapidly during this period to zero at lower agitation rate. However, the DO level at high agitation rate of $750 \mathrm{rpm}$ was always higher than the critical value of $10 \%$ for the microorganism reported by Kobayashi et al. (2000).

The efficient oxygen transfer improved the protein production in two ways. Firstly, good oxygen transfer into the microorganisms resulted in high cell density. Protein production is associated with cell growth. Therefore, the higher the cell concentration, the more protein could be produced. Secondly, efficient oxygen transfer caused sufficient oxygen provision in the system, and hence there was sufficient energy provided to the protein secretion process, resulting in a better protein production. 


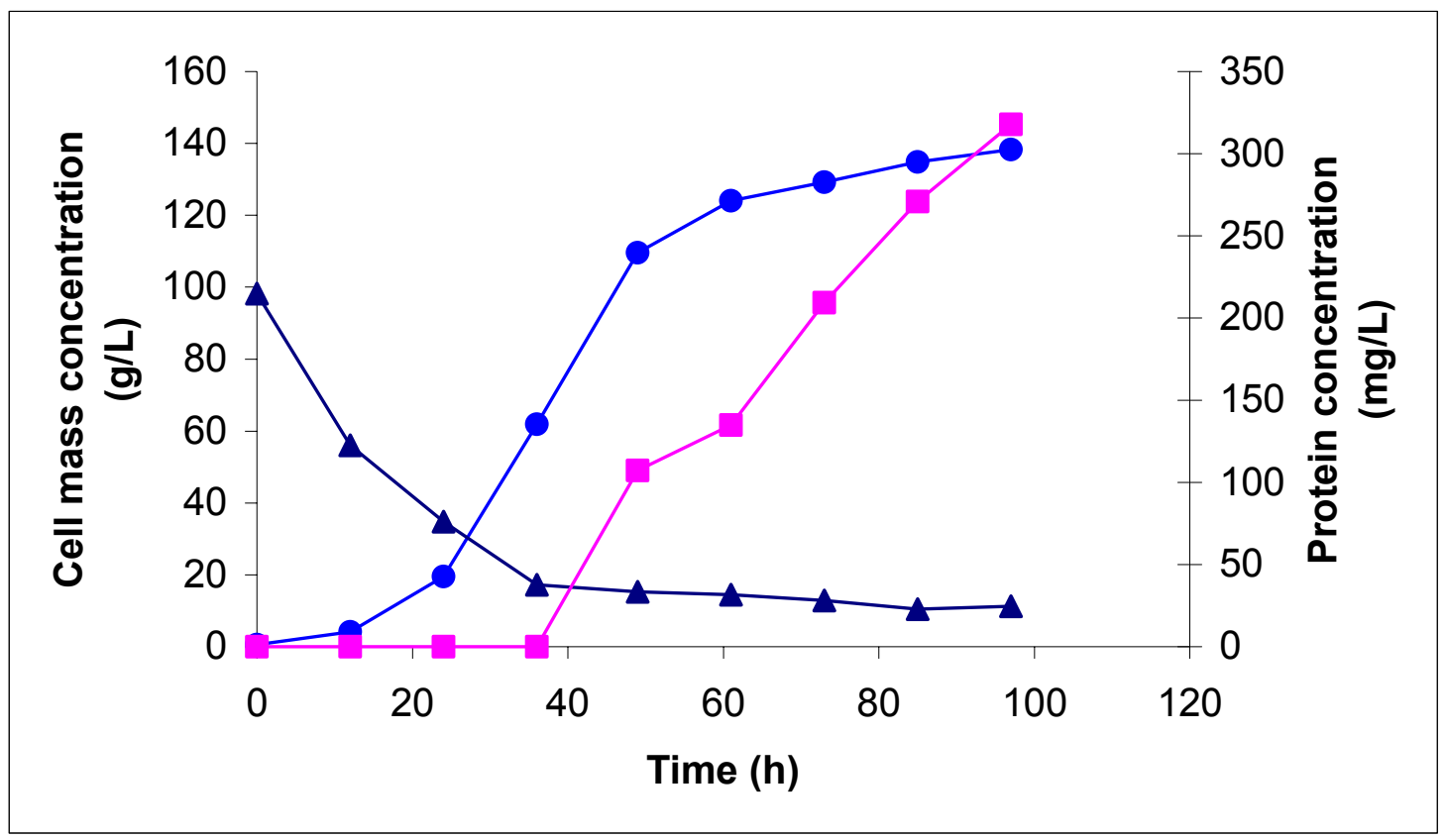

Figure 4.3 Conventionally sparged fermentation at $750 \mathrm{rpm}$

Cell mass concentration $(\bullet)$

Protein concentration ( $\square$ )

Dissolved oxygen $(\boldsymbol{\Delta})$

\subsection{MBD Sparged Fermentations}

The MBD fermentations were conducted under the same conditions as the conventionally sparged runs at agitation rate of $150 \mathrm{rpm}, 350 \mathrm{rpm}$, and $500 \mathrm{rpm}$. Previously there was no application of MBD generator to provide oxygen to P. pastoris cultivation. Kaster et al. (1990), Hensirisak (1997), and Parasukulsatid (2000) all used microbubble dispersion to supply oxygen for aerobic fermentation of Baker's yeast and showed significant improvement in oxygen transfer. The $S$. cerevisiae fermentation was performed within 48 hour, whereas in this study, $P$. pastoris was cultivated for 97 hours. A higher likelihood of a mechanical failure of the MBD generator as well as contamination of the culture associated with longer fermentation durations made the fermentation in this study more challenging. 


\subsubsection{MBD Fermentation at $150 \mathrm{rpm}$}

The positive effect of the microbubble dispersion on the system aeration capacity was first shown in the $150 \mathrm{rpm}$ MBD sparged fermentation. The cell mass growth pattern (Figure 4.4) in the MBD fermentation at this extremely low agitation rate of $150 \mathrm{rpm}$ was much better than that in the conventional fermentation at $350 \mathrm{rpm}$, and similar to that in the $500 \mathrm{rpm}$ conventional fermentation. The cell concentration at the end of the fermentation was $52.84 \mathrm{~g} / \mathrm{L}$, which was even slightly higher than the cell concentration of $48.98 \mathrm{~g} / \mathrm{L}$ in the conventionally sparged fermentation at $500 \mathrm{rpm}$ agitation.

The stable bubbles of small diameter resulted in larger specific interfacial area and longer bubble residence time, and hence, higher oxygen transfer rate in the system. Thus, the dissolved oxygen level in the $150 \mathrm{rpm}$ MBD fermentation was slightly higher than that in the $500 \mathrm{rpm}$ conventional fermentation, resulting in a better protein production. The protein concentration was $95.74 \mathrm{mg} / \mathrm{L}$ in the $150 \mathrm{rpm}$ MBD sparged fermentation compared to $67.34 \mathrm{mg} / \mathrm{L}$ protein concentration in the $500 \mathrm{rpm}$ conventionally sparged fermentation, although the cell concentration between the two fermentation runs were not very much different. The improved protein production could be explained by more dissolved oxygen in the system providing more energy to the protein secretion process. 


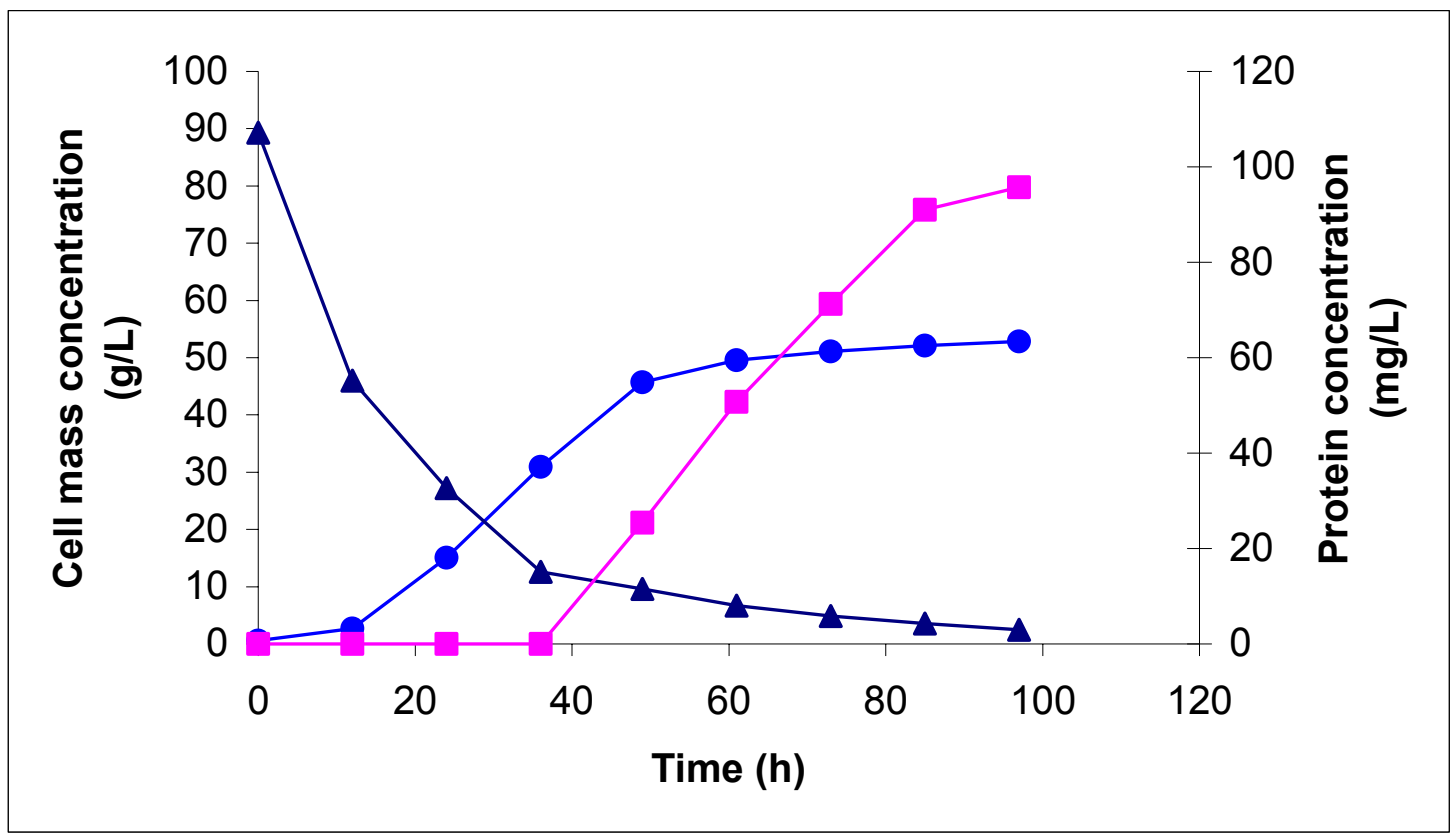

Figure 4.4 MBD sparged fermentation at $150 \mathrm{rpm}$

Cell mass concentration $(\bullet)$

Protein concentration $(\square)$

Dissolved oxygen $(\mathbf{\Delta})$

\subsubsection{MBD fermentation at $350 \mathrm{rpm}$}

The higher oxygen transfer efficiency of the microbubble dispersion was demonstrated in the MBD sparged fermentation at the agitation rate of $350 \mathrm{rpm}$. The microorganisms grew very rapidly and reached a high concentration of $129.9 \mathrm{~g} / \mathrm{L}$ (Figure 4.5), which was 4.6 times higher than the corresponding conventional system. The cell growth pattern was completely different from that at the same agitation rate of $350 \mathrm{rpm}$ in the conventionally sparged fermentation, but was more like that at high agitation rate of $750 \mathrm{rpm}$ in the conventionally sparged fermentation.

The protein production followed a similar trend as the cell growth. At $350 \mathrm{rpm}$, the protein production in the conventional fermentation was very low because of the low dissolved oxygen level. While in the $350 \mathrm{rpm}$ MBD sparged fermentation, the protein concentration was $267.3 \mathrm{mg} / \mathrm{L}$ at the end of fermentation, which was 7.3 times higher than that in the conventional 
system at $350 \mathrm{rpm}$, but was similar to that of the conventional fermentation at $750 \mathrm{rpm}$. The high protein production was associated with the high dissolved oxygen in the MBD sparged fermentation. The dissolved oxygen level was higher than the critical 10\% value, and was even higher than that in the $750 \mathrm{rpm}$ conventional fermentation due to the beneficial oxygen transfer properties of the microbubbles.

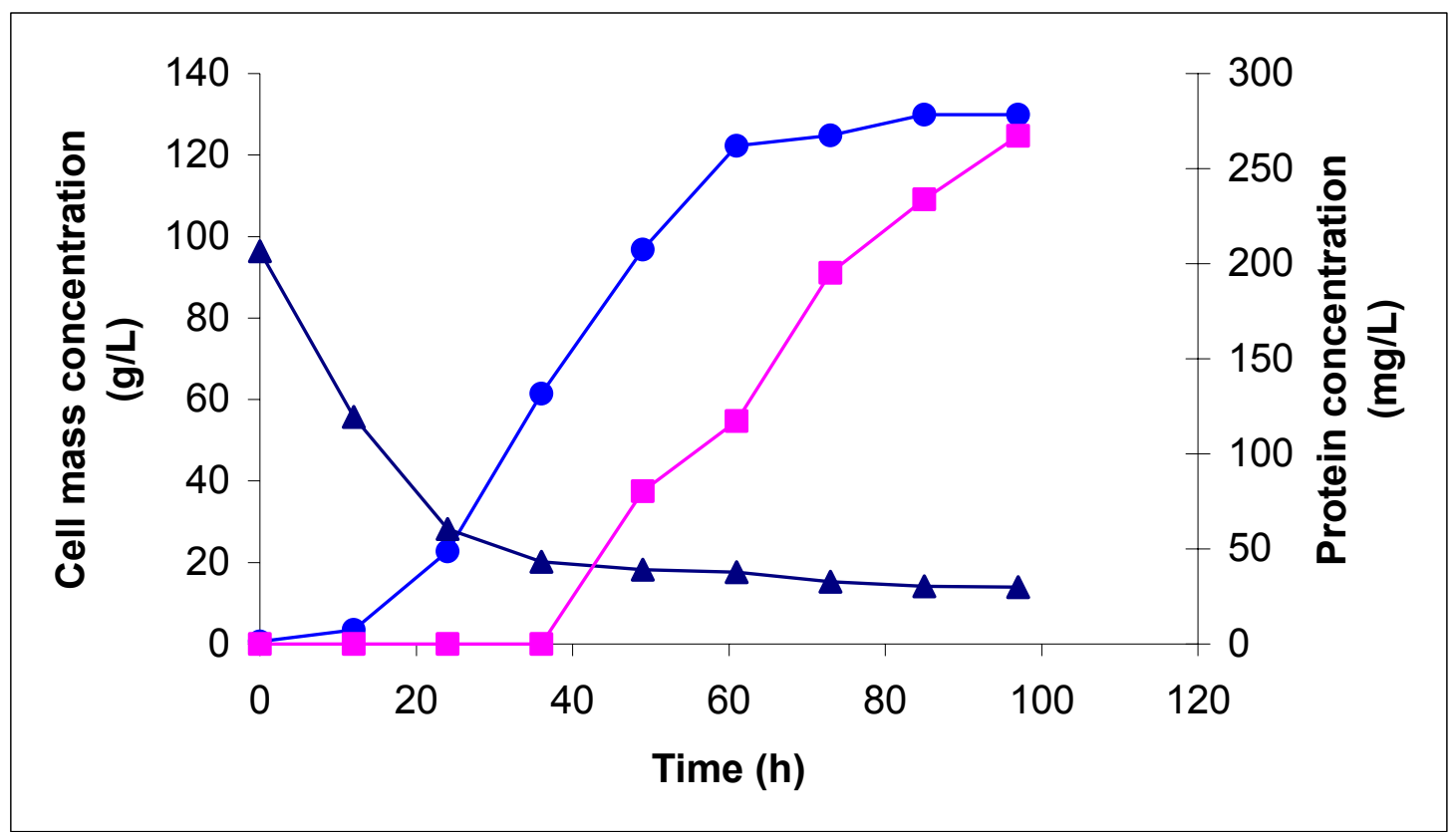

Figure 4.5 MBD sparged fermentation at $350 \mathrm{rpm}$

Cell mass concentration $(\bullet)$

Protein concentration $(\square)$

Dissolved oxygen $(\boldsymbol{\Delta})$

\subsubsection{MBD Fermentation at $500 \mathrm{rpm}$}

MBD sparged fermentation at $500 \mathrm{rpm}$ agitation rate was conducted to assess any further improvement in the fermentation with increased agitation rate. The cell growth pattern was very similar to that at $350 \mathrm{rpm}$ MBD fermentation (Figure 4.6). The cell concentration at the end of $500 \mathrm{rpm}$ MBD fermentation was $137.8 \mathrm{~g} / \mathrm{L}$, which was only slightly higher than $129.9 \mathrm{~g} / \mathrm{L}$ in the $350 \mathrm{rpm}$ MBD fermentation, but not very much different. The cell concentration achieved 
after 97 hours of fermentation at $350 \mathrm{rpm}$ and $500 \mathrm{rpm}$ agitation in the MBD sparged system, and at $750 \mathrm{rpm}$ agitation in the conventionally sparged system were not pronouncedly different.

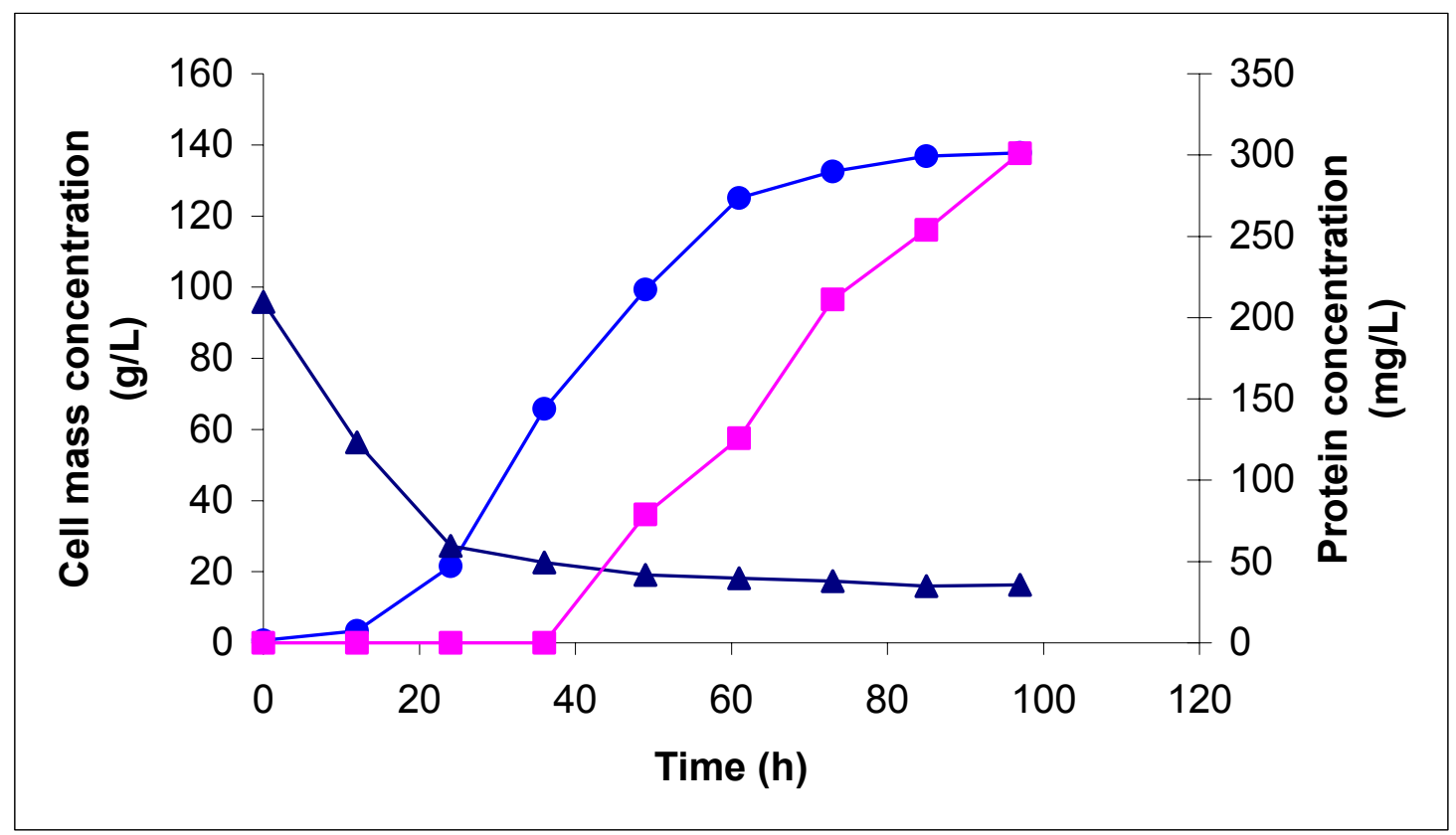

Figure 4.6 MBD sparged fermentation at $500 \mathrm{rpm}$

Cell mass concentration $(\bullet)$

Protein concentration $(\square)$

Dissolved oxygen $(\boldsymbol{\Delta})$

The protein production curve was also similar to those in the $350 \mathrm{rpm}$ MBD fermentation and $750 \mathrm{rpm}$ conventional fermentation. The protein concentration of $301.2 \mathrm{mg} / \mathrm{L}$ was similar to that in the $750 \mathrm{rpm}$ conventional fermentation. Protein production was dependent on cell mass concentration and energy provision in the system. Similar cell growth resulted in the similar protein production. Dissolved oxygen levels in the $500 \mathrm{rpm}$ MBD fermentation were also higher than the critical value, which was the reason why similar cell concentrations could be achieved. Although the DO levels at $500 \mathrm{rpm}$ were slightly higher than those at $350 \mathrm{rpm}, \mathrm{MBD}$ fermentation results at $500 \mathrm{rpm}$ were similar to those at $350 \mathrm{rpm}$, and this showed that there was no need to increase the agitation beyond $350 \mathrm{rpm}$. 


\subsection{Comparison between Conventionally and MBD Sparged Systems}

The fermentation industry primarily uses stirred tank fermenters. The power input per volume of broth in a laboratory fermenter can be as much as 1000 times greater than the power input per volume of broth in an industrial fermenter. Any improvements seen in a laboratory scale fermenter will be significantly greater in an industrial fermenter. The goal of the MBD technology development is to increase oxygen transfer at low agitation rate to growing microorganisms in a stirred-tank reactor because the power consumption is proportional to impeller rate to the third power. Attaining this goal will decrease the operating cost of aerobic fermentation processes, because a large fraction of the process cost is associated with power requirements for agitation.

Conventionally sparged fermentations at $350 \mathrm{rpm}, 500 \mathrm{rpm}$, and $750 \mathrm{rpm}$, and MBD sparged fermentations at $150 \mathrm{rpm}, 350 \mathrm{rpm}$ and $500 \mathrm{rpm}$ were conducted in the $1.6 \mathrm{~L}$ Bioflo III fermenter. Cell production, protein production, and dissolved oxygen profile were compared between the two systems (Figure 4.7 - 4.9).

In the MBD sparged system, cell mass concentrations achieved at $350 \mathrm{rpm}$ and $500 \mathrm{rpm}$ were not very much different. While in the conventionally sparged system, cell mass concentration at $500 \mathrm{rpm}$ was 1.8 times greater than that at $350 \mathrm{rpm}$ (Table 4.1). Cell growth pattern for MBD sparged fermentation at $350 \mathrm{rpm}$ and $500 \mathrm{rpm}$ were also very similar to that for conventionally sparged fermentation at $750 \mathrm{rpm}$. Therefore, MBD sparged fermentation at low agitation rate of $350 \mathrm{rpm}$ could achieve similar cell production as conventionally sparged fermentation at high agitation rate of $750 \mathrm{rpm}$. It was also demonstrated that the cell growth pattern in the $150 \mathrm{rpm}$ MBD fermentation was similar to that in the $500 \mathrm{rpm}$ conventional fermentation. 


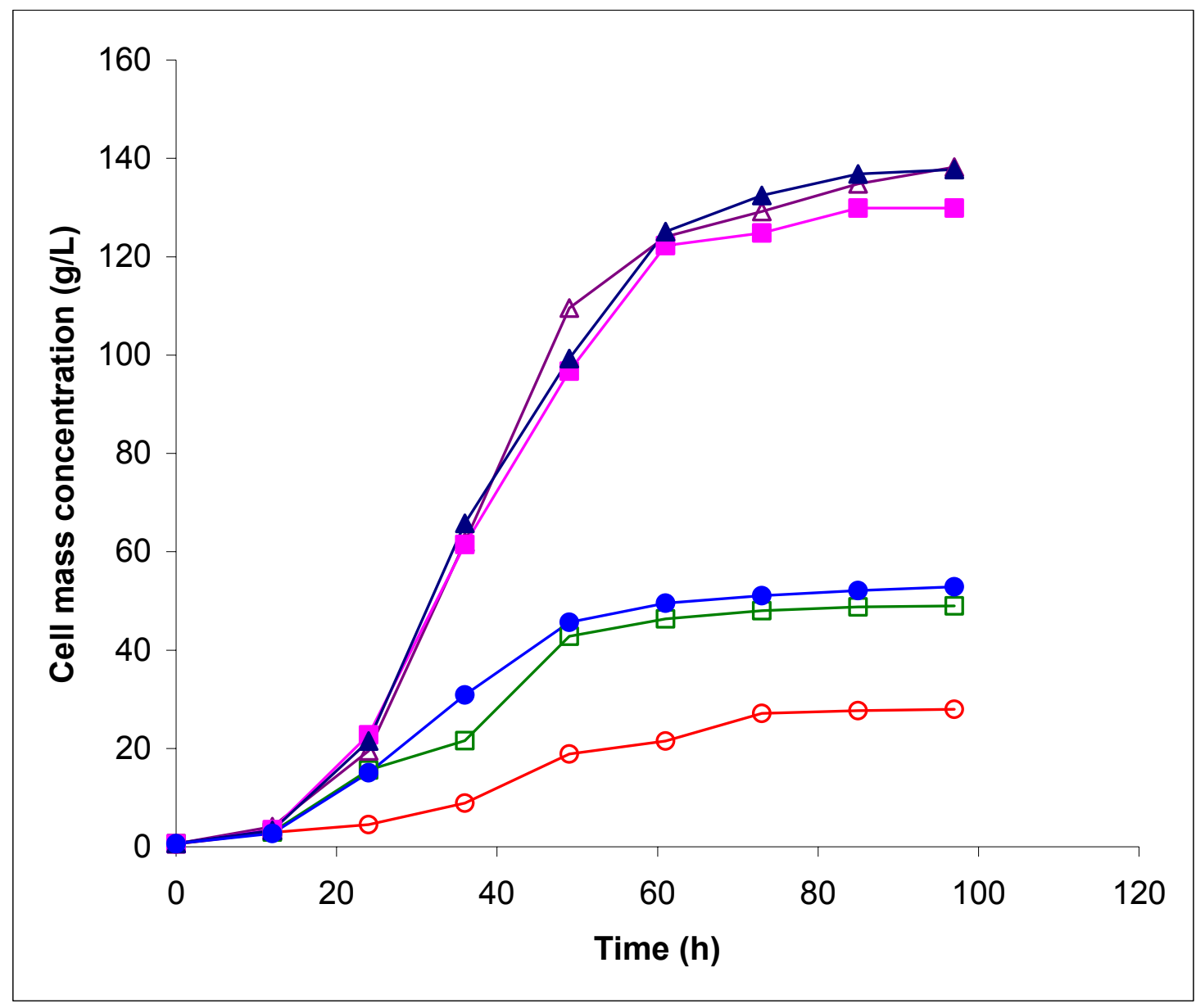

Figure 4.7 Comparison of cell growth between MBD and conventional systems

Conventional fermentaion at $350 \mathrm{rpm}(\circ)$

Conventional fermentaion at $500 \mathrm{rpm}(\square)$

Conventional fermentaion at $750 \mathrm{rpm}(\triangle)$

MBD fermentaion at $150 \mathrm{rpm}(\bullet)$

MBD fermentaion at $350 \mathrm{rpm}(\square)$

MBD fermentaion at $500 \mathrm{rpm}(\boldsymbol{\Delta})$ 


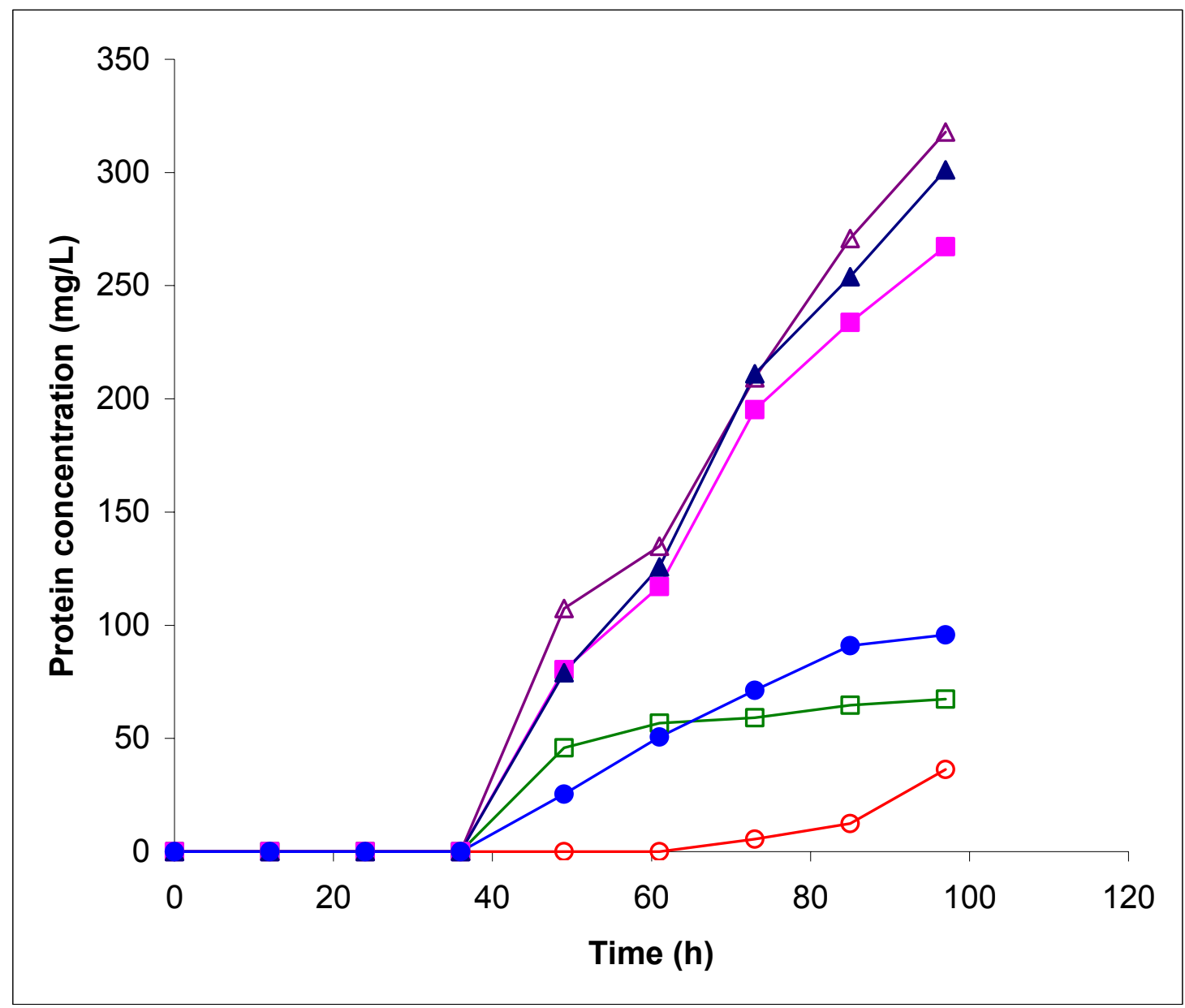

Figure 4.8 Comparison of protein formation between MBD and conventional systems

Conventional fermentaion at $350 \mathrm{rpm}(\circ)$

Conventional fermentaion at $500 \mathrm{rpm}(\square)$

Conventional fermentaion at $750 \mathrm{rpm}(\triangle)$

MBD fermentaion at $150 \mathrm{rpm}(\bullet)$

MBD fermentaion at $350 \mathrm{rpm}$ ( $\square$ )

MBD fermentaion at $500 \mathrm{rpm}(\boldsymbol{\Delta})$ 


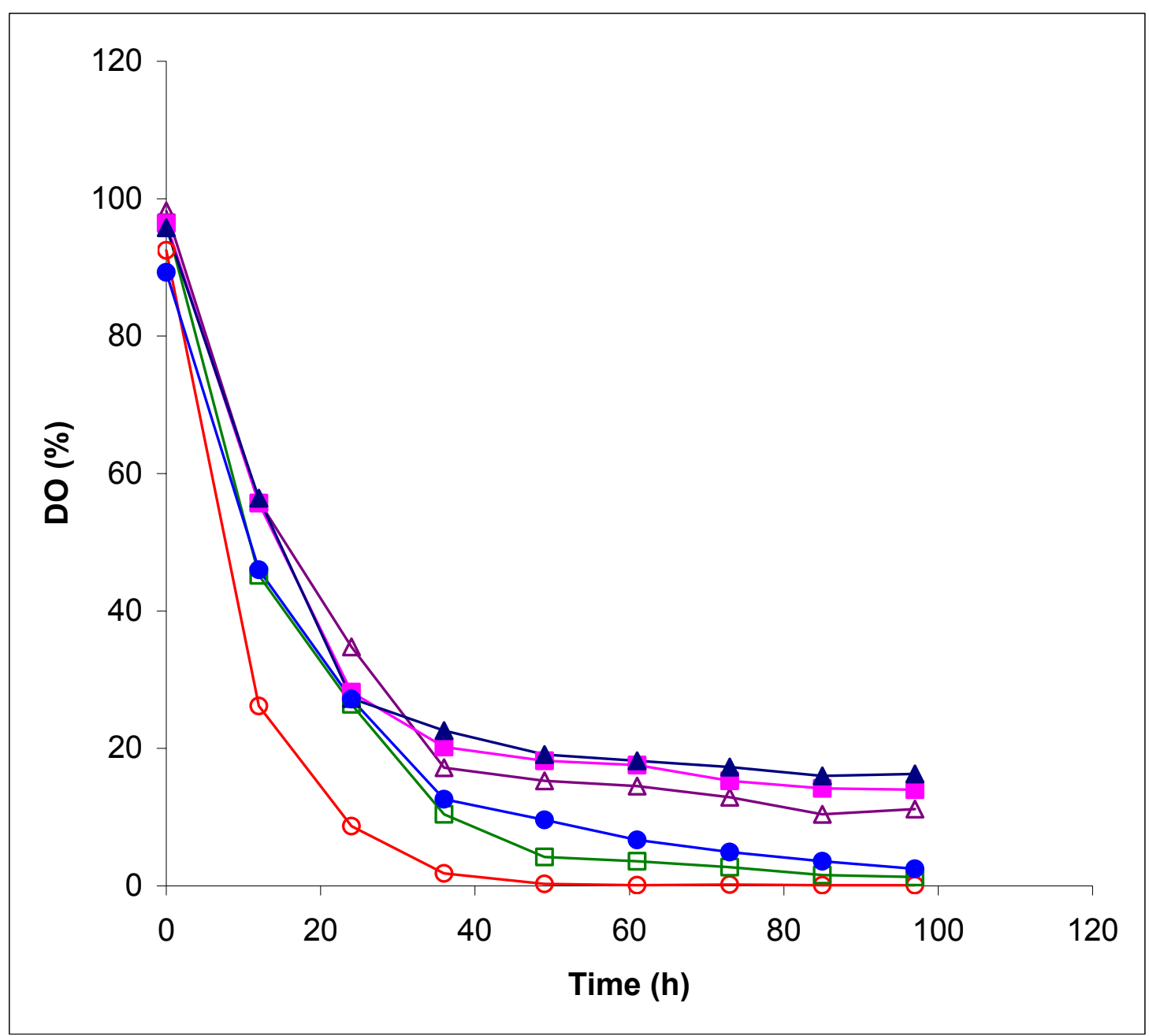

Figure 4.9 Comparison of dissolved oxygen between MBD and conventional systems

Conventional fermentaion at $350 \mathrm{rpm}(\circ)$

Conventional fermentaion at $500 \mathrm{rpm}(\square)$

Conventional fermentaion at $750 \mathrm{rpm}(\triangle)$

MBD fermentaion at $150 \mathrm{rpm}(\bullet)$

MBD fermentaion at $350 \mathrm{rpm}(\square)$

MBD fermentaion at $500 \mathrm{rpm}(\boldsymbol{\Delta})$ 
Table 4.1 Final cell mass concentration, protein concentration, substrate yield, and product yield comparison between MBD and air sparging systems

\begin{tabular}{|c|c|c|c|c|c|}
\hline $\begin{array}{c}\text { Fermentation } \\
\text { type }\end{array}$ & $\begin{array}{l}\text { Agitation } \\
\text { rate (rpm) }\end{array}$ & $\begin{array}{c}\text { Cell mass } \\
\text { concentration } \\
(\mathrm{g} / \mathrm{L})\end{array}$ & $\begin{array}{c}\text { Protein } \\
\text { concentration } \\
(\mathrm{mg} / \mathrm{L})\end{array}$ & $\begin{array}{c}\text { Ys } \\
\text { (g cell /g } \\
\text { glycerol }\end{array}$ & $\begin{array}{c}\mathrm{Y}_{\mathrm{P}} \\
(\text { mg protein } \\
/ \mathrm{g} \text { methanol ) }\end{array}$ \\
\hline $\begin{array}{c}\text { Conventionally } \\
\text { sparged }\end{array}$ & 350 & 27.95 & 36.29 & 0.334 & 1.57 \\
\hline $\begin{array}{c}\text { Conventionally } \\
\text { sparged }\end{array}$ & 500 & 48.98 & 67.34 & 0.390 & 2.38 \\
\hline $\begin{array}{c}\text { Conventionally } \\
\text { sparged }\end{array}$ & 750 & 138.2 & 317.9 & 0.438 & 5.21 \\
\hline $\begin{array}{c}\text { MBD } \\
\text { Sparged }\end{array}$ & 150 & 52.84 & 95.74 & 0.405 & 2.49 \\
\hline $\begin{array}{c}\text { MBD } \\
\text { Sparged }\end{array}$ & 350 & 129.9 & 267.3 & 0.431 & 5.02 \\
\hline $\begin{array}{c}\text { MBD } \\
\text { sparged }\end{array}$ & 500 & 137.8 & 301.2 & 0.450 & 5.15 \\
\hline
\end{tabular}

Production of proteins was associated with cell growth pattern, and thus showed similar trend as cell growth. Protein production in the MBD sparged fermentation at $350 \mathrm{rpm}$ and 500 rpm were not considerably different from that in the $750 \mathrm{rpm}$ conventionally sparged fermentation. Protein concentrations at the end of the fermentation run were $267.3 \mathrm{mg} / \mathrm{L}, 301.2$ $\mathrm{mg} / \mathrm{L}$, and $317.9 \mathrm{mg} / \mathrm{L}$ at $350 \mathrm{rpm}$ MBD fermentation, $500 \mathrm{rpm}$ MBD fermentation, and 750 rpm conventional fermentation, respectively (Table 4.1). The level of protein concentration achieved was similar to that reported by Kobayashi et al. (2000). Protein concentration of MBD fermentation at $150 \mathrm{rpm}$ was also slightly higher than that at $500 \mathrm{rpm}$ conventional fermentation (Table 4.1). 
Dissolved oxygen profile also showed that MBD increased the oxygen transfer efficiency at low agitation rate (Figure 4.9). DO levels at $350 \mathrm{rpm} \mathrm{MBD,} 500 \mathrm{rpm}$ MBD, and $750 \mathrm{rpm}$ conventional were above the critical DO level at the end of the fermentation. DO levels at both $350 \mathrm{rpm}$ MBD fermentation and $500 \mathrm{rpm}$ MBD fermentation were slightly higher than DO at $750 \mathrm{rpm}$ conventional fermentation. For the conventional system at $350 \mathrm{rpm}$ and $500 \mathrm{rpm}$, the dissolved oxygen decreased to almost zero, showing severe oxygen limitation in the system. The MBD fermentation at $150 \mathrm{rpm}$ also showed oxygen limitation with DO decreasing below the critical value. However, the DO decrease at $150 \mathrm{rpm}$ MBD fermentation was still slightly slower than that at $350 \mathrm{rpm}$ and $500 \mathrm{rpm}$ conventional fermentations.

Therefore, the comparison of cell growth, protein production, and dissolved oxygen profile between two systems showed more efficient oxygen transfer in the MBD system.

\subsection{Productivities}

Volumetric productivity is expressed as gram of product per liter per hour and is a measure of the overall performance of a process. In the continuous or fed-batch fermentation processes, the maximum productivity does not necessarily occur at a dilution rate corresponding to the maximum yield or conversion of substrate to cells, and cell mass maximal productivity may not occur at the same time as the appearance of the product maximal productivity. Below, cell mass productivities and protein productivities were summarized for each run.

\subsubsection{Cell Mass Productivity}

Cell mass productivities for the conventionally and MBD sparged fermentation runs at different agitation rates are shown in Figure 4.10. All the productivity curves peaked at the same fermentation time at $49 \mathrm{~h}$. The apparent maximum attained in the cell mass productivity was attributed to the change in the substrate from glycerol to methanol. Metabolism of methanol is slower than glycerol and therefore the cell mass productivity decreased.

Cell mass productivities at $350 \mathrm{rpm}$ and $500 \mathrm{rpm}$ in the MBD sparged system were similar to the productivity at $750 \mathrm{rpm}$ in the conventionally sparged system with the highest rate at $49 \mathrm{~h}$, then decreasing gradually till $97 \mathrm{~h}$. It was demonstrated that high oxygen transfer led to 
high cell mass productivity in this fermentation process. The maximum productivity value $(2.2 \mathrm{~g}$ / $(\mathrm{L} \cdot \mathrm{h})$ ) occurred at $49 \mathrm{~h}$ in the $750 \mathrm{rpm}$ conventional fermentation. Although $500 \mathrm{rpm}$ MBD fermentation had a slightly lower maximum value $(2.0 \mathrm{~g} /(\mathrm{L} \bullet \mathrm{h}))$ than the $750 \mathrm{rpm}$ conventional fermentation, the productivity was maintained at that level for $12 \mathrm{~h}$ compared to the rapid drop in the conventional system. The $350 \mathrm{rpm}$ MBD fermentation cell mass productivity showed the similar pattern as the one of $500 \mathrm{rpm}$ MBD fermentation, and had a maximum value of $2.0 \mathrm{~g} /$ $(\mathrm{L} \cdot \mathrm{h})$, again showing similar oxygen transfer efficiency to the $500 \mathrm{rpm}$ MBD fermentation.

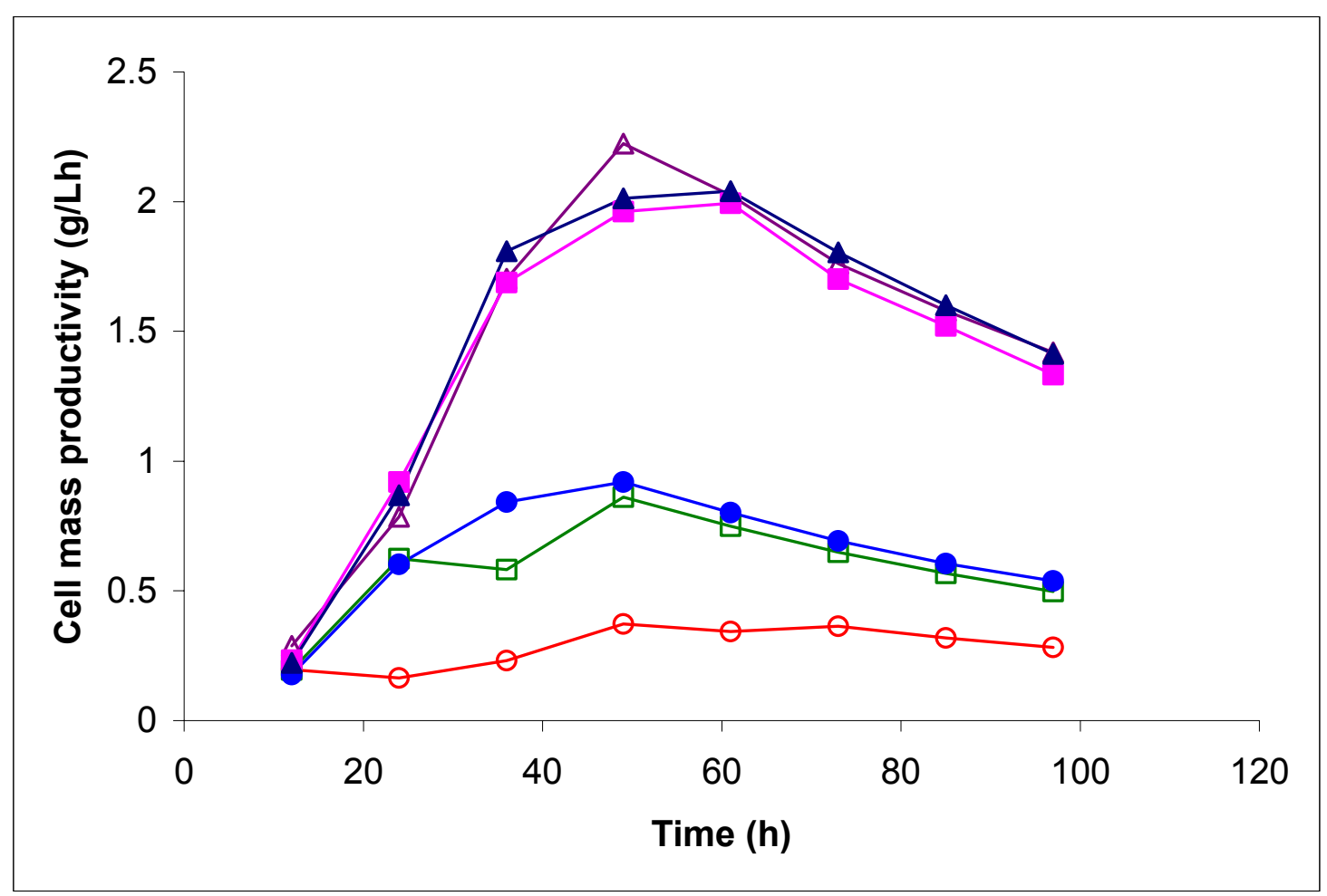

Figure 4.10 Cell mass productivity in MBD and conventionally sparged systems

Conventional fermentaion at $350 \mathrm{rpm}(\mathrm{\circ})$

Conventional fermentaion at $500 \mathrm{rpm}(\square)$

Conventional fermentaion at $750 \mathrm{rpm}(\triangle)$

MBD fermentaion at $150 \mathrm{rpm}(\bullet)$

MBD fermentaion at $350 \mathrm{rpm} \mathrm{(} \square)$

MBD fermentaion at $500 \mathrm{rpm}(\boldsymbol{\Delta})$ 
The conventionally sparged fermentation at low agitation rate showed poor cell mass productivity, with maximum value of $0.37 \mathrm{~g} /(\mathrm{L} \bullet \mathrm{h})$ and $0.86 \mathrm{~g} /(\mathrm{L} \bullet \mathrm{h})$ at $350 \mathrm{rpm}$ and $500 \mathrm{rpm}$, respectively. The effect of poor oxygen transfer on cell mass productivity could be clearly seen in the productivity pattern of $350 \mathrm{rpm}$ conventional fermentation, with the productivity curve considerably flat and no obvious peak. The lower agitation rate of $150 \mathrm{rpm}$ fermentation but using MBD sparging again showed the benefit of the MBD system, with a maximum productivity of $0.92 \mathrm{~g} /(\mathrm{L} \bullet \mathrm{h})$, which was slightly higher than the $500 \mathrm{rpm}$ conventional fermentation.

\subsubsection{Protein Productivity}

As the primary goal of the fermentation is to produce rHSA, the protein productivity is of special interest and can be used as a benchmark for the effectiveness of the fermentations. The protein productivities of the MBD and conventionally sparged fermentations are shown in Figure 4.11.

It can be seen that the protein production started at about $37 \mathrm{~h}$ of fermentation. The protein productivity patterns at $350 \mathrm{rpm}$ and $500 \mathrm{rpm}$ in the MBD system were very similar, increased very rapidly from $36 \mathrm{~h}$ to $49 \mathrm{~h}$ and then slowed down. The productivity appeared to plateau after $75 \mathrm{~h}$. The maximum protein productivities for $350 \mathrm{rpm}$ and $500 \mathrm{rpm}$ MBD were 2.8 $\mathrm{mg} /(\mathrm{L} \cdot \mathrm{h})$ and $3.1 \mathrm{mg} /(\mathrm{L} \cdot \mathrm{h})$, respectively. The maximum protein productivity for $750 \mathrm{rpm}$ conventional fermentation was $3.3 \mathrm{mg} /(\mathrm{L} \bullet \mathrm{h})$ and slightly higher than those in the MBD fermentations, but the difference was not pronounced. Thus, the MBD system at low agitation rate could achieve similar fermentation as the high agitation rate of $750 \mathrm{rpm}$ in a conventional system.

The protein productivity in the $350 \mathrm{rpm}$ conventional system was very low and attained the highest level of only $0.37 \mathrm{mg} /(\mathrm{L} \cdot \mathrm{h})$ at $97 \mathrm{~h}$. The protein productivity pattern at $500 \mathrm{rpm}$ conventional fermentation was unusual, with a maximum value of $0.94 \mathrm{mg} /(\mathrm{L} \bullet \mathrm{h})$ at $49 \mathrm{~h}$ and decreasing slowly till $97 \mathrm{~h}$. The reason for this phenomenon was still not clear, and was probably because poor dissolved oxygen in the system may affect the protein secretion process. Associated with the slightly better cell mass productivity at $150 \mathrm{rpm} \mathrm{MBD}$, the protein 
productivity was also slightly higher than that at $500 \mathrm{rpm}$ in the conventional fermentation, with a maximum value of $1.1 \mathrm{mg} /(\mathrm{L} \cdot \mathrm{h})$.

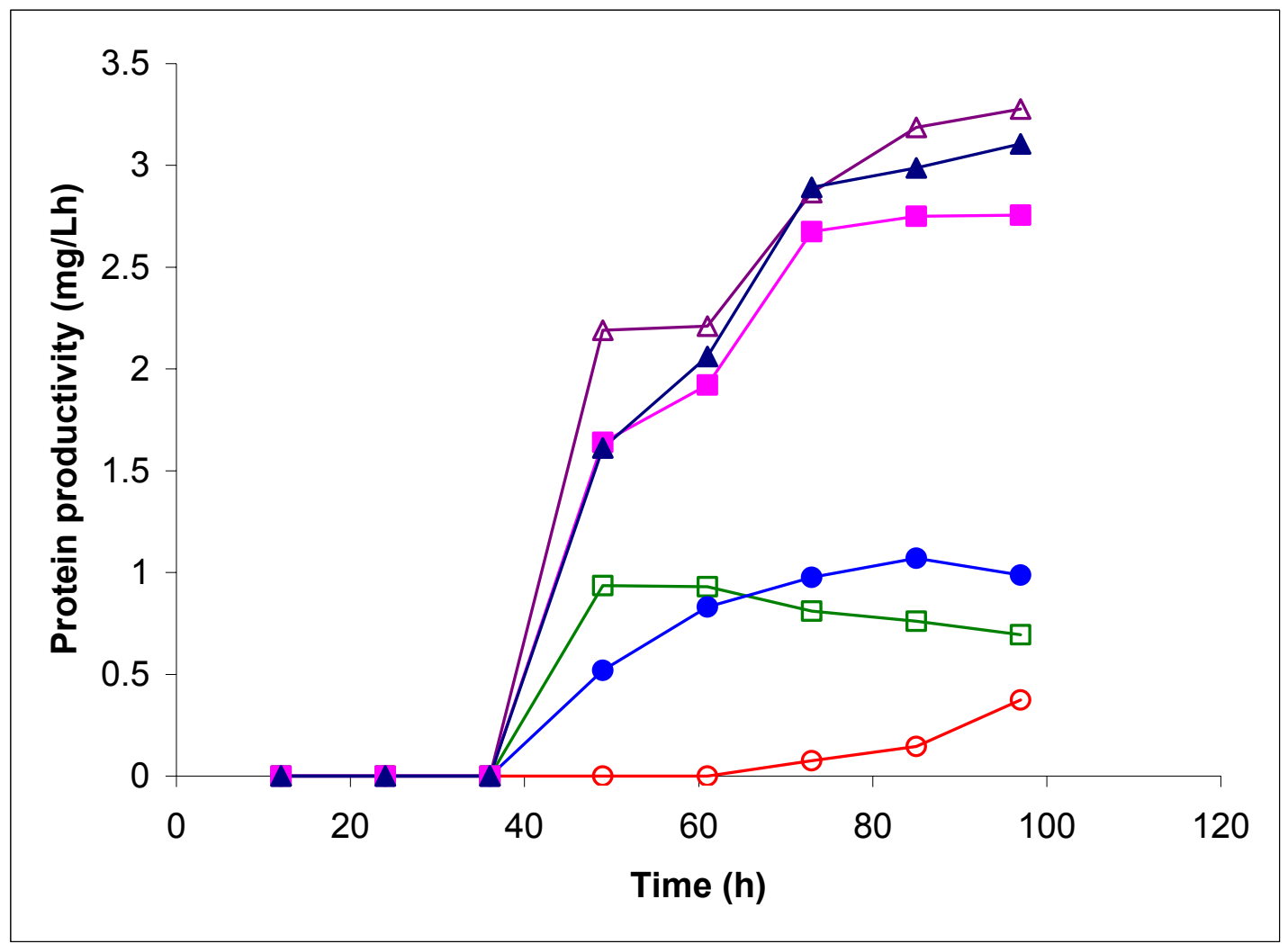

Figure 4.11 Protein productivity in MBD and conventionally sparged systems

Conventional fermentaion at $350 \mathrm{rpm}(\circ)$

Conventional fermentaion at $500 \mathrm{rpm}(\square)$

Conventional fermentaion at $750 \mathrm{rpm}(\triangle)$

MBD fermentaion at $150 \mathrm{rpm}(\bullet)$

MBD fermentaion at $350 \mathrm{rpm}(\square)$

MBD fermentaion at $500 \mathrm{rpm}(\boldsymbol{\Delta})$

From the cell mass productivity and protein productivity, it could be seen that cell mass productivity reached its highest level at $49 \mathrm{~h}$ of fermentation. After $49 \mathrm{~h}$ both cell growth rate and the protein production rate slowed down till the end of the fermentation. Cell mass productivity patterns and protein productivity patterns between MBD and conventional system 
also showed MBD at low agitation rate achieved similar results to that at high agitation rate in the conventional system.

\subsection{Specific Rate of Protein Production}

Microbial growth, product formation, and substrate utilization rates are usually expressed in the form of specific rates (e.g., normalized with respect to $X$ ), since bioreactions are autocatalytic. The specific rates are used to compare the effectiveness of various fermentation schemes and biocatalysts. Thus, the specific rate of product formation is $q_{p}=\frac{1}{X} \frac{d P}{d t}$, where $P$ is the product concentration, $\frac{d P}{d t}$ is the product formation rate, and $X$ is the cell mass concentration. Microbial products can be classified in three major categories (Shuler and Kargi, 1999):

1. Growth-associated products are produced simultaneously with microbial growth. The specific product formation rate $q_{p}$ is proportional to the specific rate of growth $\mu_{\mathrm{g}}, q_{p}=\alpha$ $\mu_{\mathrm{g}}$

2. Nongrowth-associated product formation takes place during the stationary phase when the growth rate is zero. The specific production formation rate is constant, $q_{p}=\beta$.

3. Mixed-growth-associated product formation takes place during the slow growth and stationary phases. The specific product formation rate follows the equation, $q_{p}=\alpha \mu_{\mathrm{g}}+\beta$.

In this study, protein is the desired product, thus $q_{p}$ stands for the specific rate of protein production. It was observed that specific protein production rate $q_{p}$ is a function of specific growth rate of the microorganism, $\mu_{\mathrm{g}}$, and the following equations were developed for different fermentation runs:

Conventional fermentation at $500 \mathrm{rpm}$,

$$
q_{p}=0.4724 \mu_{\mathrm{g}}-0.0018 \quad\left(\mathrm{R}^{2}=0.9977\right)
$$


Conventional fermentation at $750 \mathrm{rpm}$,

$$
q_{p}=0.5685 \mu_{\mathrm{g}}-0.00191 \quad\left(\mathrm{R}^{2}=0.9796\right)
$$

MBD fermentation at $350 \mathrm{rpm}$,

$$
q_{p}=0.538 \mu_{\mathrm{g}}-0.00149 \quad\left(\mathrm{R}^{2}=0.8796\right)
$$

MBD fermentation at $500 \mathrm{rpm}$,

$$
q_{p}=0.5501 \mu_{\mathrm{g}}-0.00166 \quad\left(\mathrm{R}^{2}=0.8882\right)
$$

From the equation it can be seen that the protein production belongs to the third category of mixed-growth-associated product formation. Protein was produced in the slow cell growth stage.

\subsection{Influence of Fermenter Design}

Conventionally sparged fermentation was also conducted in a 1-L Biostat Q fermenter (B. Braun Biotech Inc., Allentown, PA) with $750 \mathrm{ml}$ working volume to compare with those conducted in the 1.6-L Bioflo III fermenter. All the fermentation conditions were the same for the two fermenters. The $\mathrm{pH}$ and temperature of the fermentation were maintained at 5.80 and 30 ${ }^{\circ} \mathrm{C}$, respectively. Agitation rates were $500 \mathrm{rpm}, 750 \mathrm{rpm}$, and $1000 \mathrm{rpm}$. Cell mass concentration, protein production, and dissolved oxygen profile were investigated.

\subsection{1 $750 \mathrm{ml}$ Fermentation at 500 rpm}

Conventionally sparged fermentation in the small 1-L reactor was first conducted at 500 rpm agitation rate. Cell growth seemed to be very slow at this agitation in the small fermenter, showing severe oxygen limitation in the system. Dissolved oxygen level decreased rapidly to zero after $36 \mathrm{~h}$ of fermentation. The cell mass concentration was $12.69 \mathrm{~g} / \mathrm{L}$ at the end of the run. There was no detectable protein produced in the fermentation broth. This was probably because of the extremely low cell concentration, since the protein production is growth associated. It may also be because of severe oxygen limitation throughout the fermentation causing relatively low glycerol utilization, and thus, there was always extra glycerol in the medium so that the microorganism could not switch to the methanol metabolizing pathway to produce human serum albumin. 


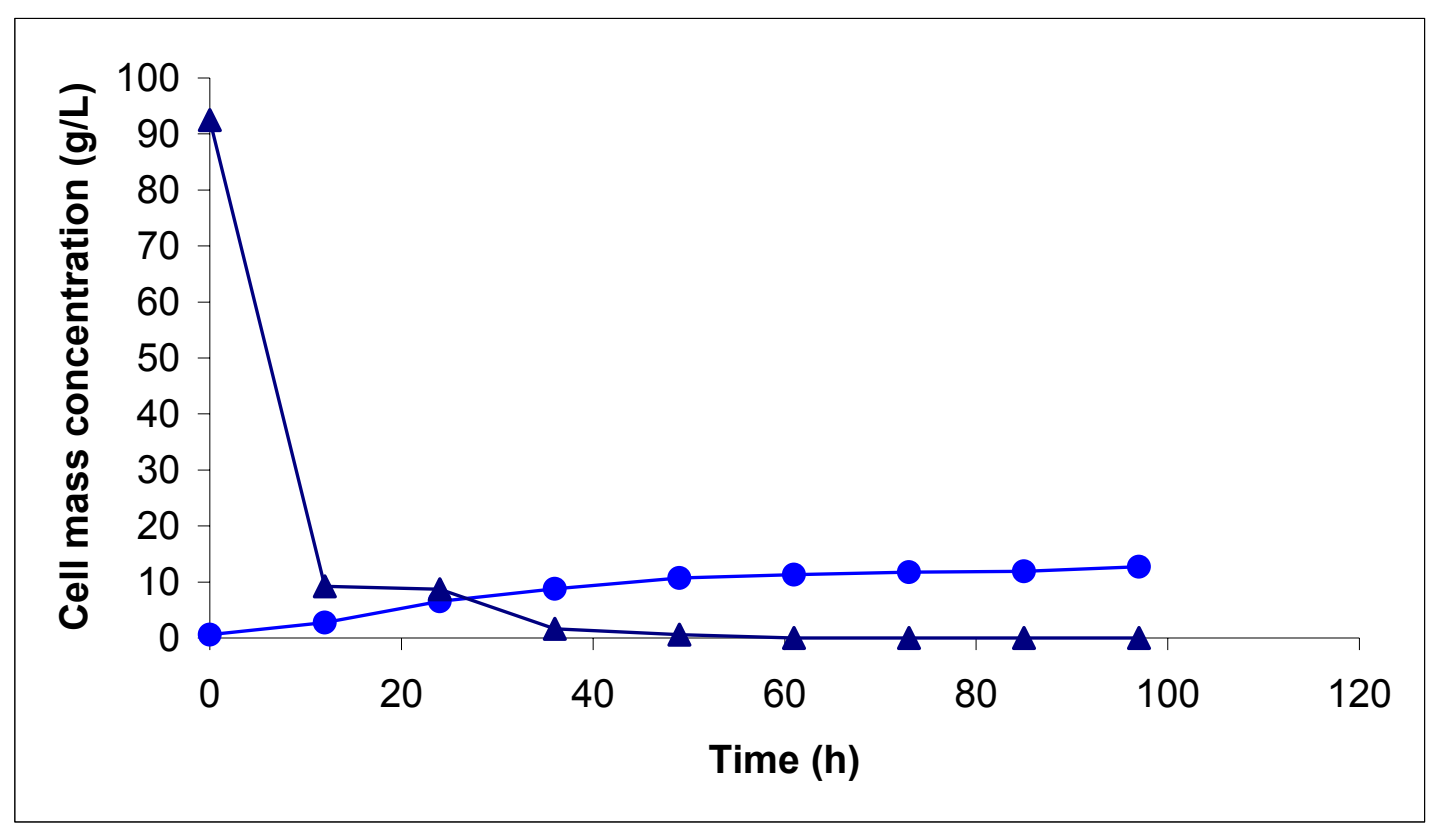

Figure $4.12750 \mathrm{ml}$ fermentation at $500 \mathrm{rpm}$

Cell mass concentration $(\bullet)$

Dissolved oxygen $(\boldsymbol{\Delta})$

\subsection{2 $750 \mathrm{ml}$ fermentation at $750 \mathrm{rpm}$}

When the agitation rate was increased to $750 \mathrm{rpm}$ in the $750 \mathrm{ml}$ conventional fermentation, the oxygen transfer was higher than that achieved with $500 \mathrm{rpm}$, and thus the better cell growth and protein production occurred (Figure 4.13).

Figure 4.13 showed a much slower dissolved oxygen decrease at $750 \mathrm{rpm}$ compared to the $500 \mathrm{rpm}$. Cell mass concentration increased to $29.74 \mathrm{~g} / \mathrm{L}$, which was almost double that at $500 \mathrm{rpm}$ fermentation. Protein was produced, although at a very low concentration. Compared to the conventionally sparged fermentation conducted in the $1.6-\mathrm{L}$ fermenter at the same agitation rate of $750 \mathrm{rpm}$, cell mass concentration was 4.6 times less. The protein production associated with cell growth showed the same trend, with a concentration of $69.52 \mathrm{mg} / \mathrm{L}$, which was also 4.6 times less than that at $750 \mathrm{rpm}$ in the $1.6-\mathrm{L}$ fermenter. 


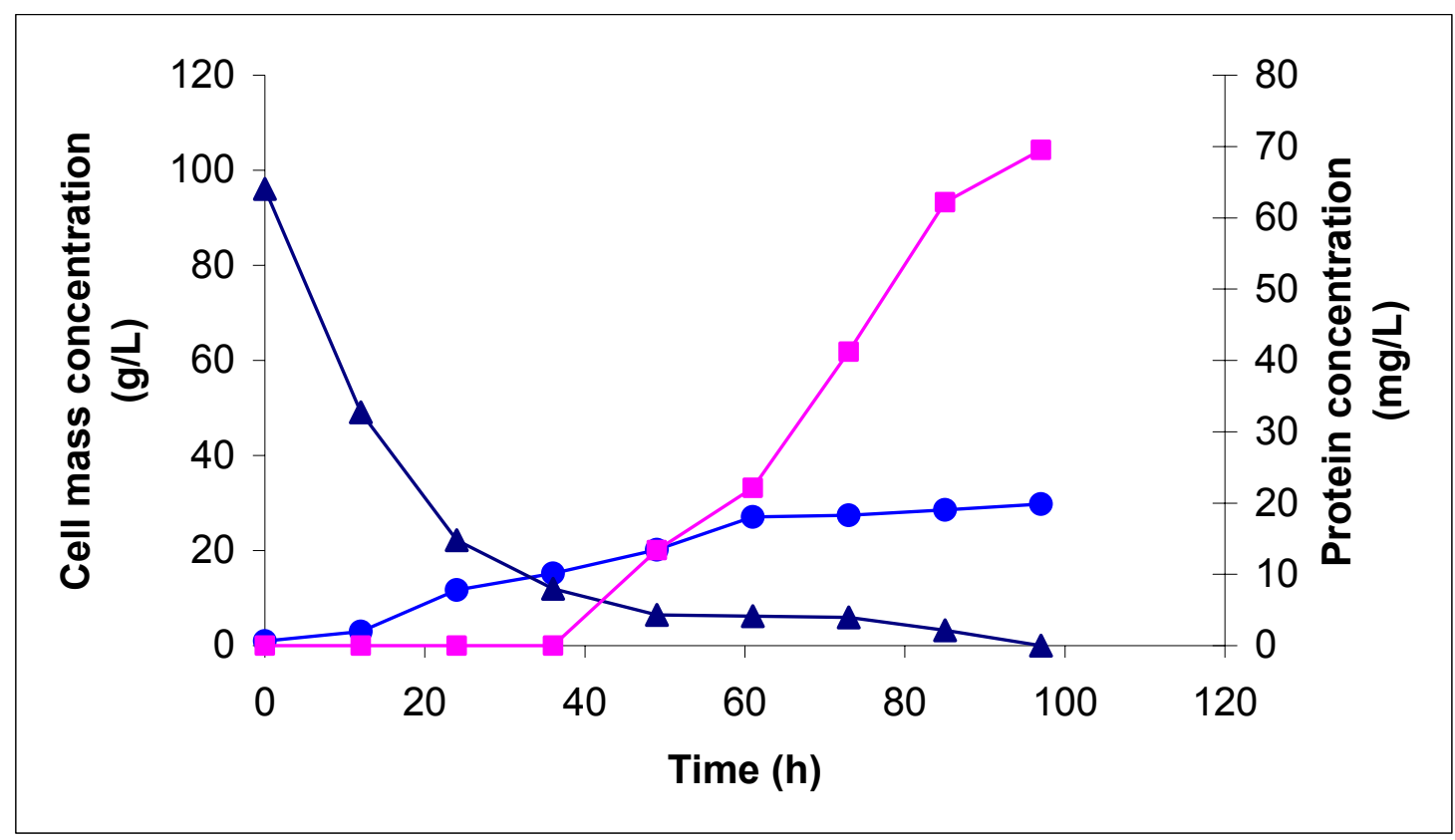

Figure $4.13750 \mathrm{ml}$ fermentation at $750 \mathrm{rpm}$

Cell mass concentration $(\bullet)$

Protein concentration ( $\square$ )

Dissolved oxygen $(\boldsymbol{\Delta})$

\subsection{3 $750 \mathrm{ml}$ Fermentation at $1000 \mathrm{rpm}$}

Cell growth at high agitation rate of $1000 \mathrm{rpm}$ in the small fermenter was much faster than those at lower agitation rates. Cell growth was very fast during the initial $49 \mathrm{~h}$ of fermentation and then slowed down (Figure 4.14). The final cell mass concentration was $57.09 \mathrm{~g}$ / L after $97 \mathrm{~h}$. This growth pattern was similar to those described previously in the large fermenter. The associated protein production was correspondingly higher and reached $100.0 \mathrm{mg} /$ $\mathrm{L}$ of protein at the end of the fermentation. The improved cell production and protein production was due to the higher agitation speed causing better oxygen delivery to the microorganisms. 


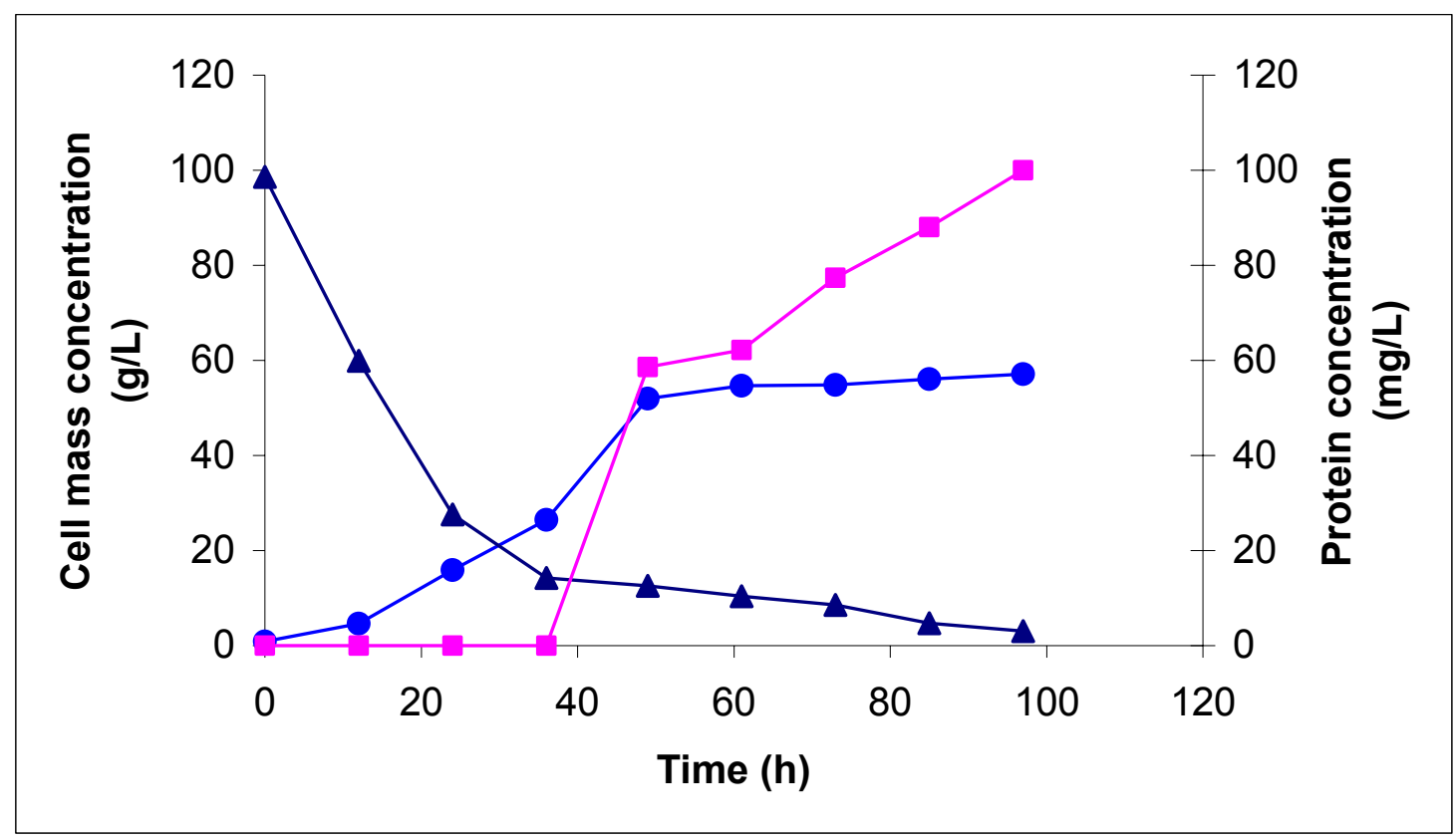

Figure $4.14750 \mathrm{ml}$ fermentation at $1000 \mathrm{rpm}$

Cell mass concentration $(\bullet)$

Protein concentration ( $\square$ )

Dissolved oxygen $(\boldsymbol{\Delta})$

With the increased agitation speed, cell mass concentration and protein concentration achieved in the conventional fermentation increased considerably. High agitation speed increased the oxygen transfer because the conventionally sparged system had insufficient gas distribution at low agitation speed. As the agitation speed increased, the gas dispersion in the fermentation medium also increased, leading to a more efficient oxygen transfer. Therefore, the agitation speed affects the aerobic fermentation performance considerably. 


\subsubsection{Comparison Between the Two Reactors}

Conventionally sparged fermentations were conducted in both a 1-L Biostat Q fermenter and 1.6-L Bioflo III fermenter at different agitation rates. Cell growth pattern, protein production pattern, and dissolved oxygen profile were compared between the two different fermenters to see the effect of fermenter design on oxygen transfer efficiency (Figure 4.15 - 4.17).

It was shown that after 97 hours of fermentation, cell concentrations in the 1.6-L reactor were much higher than those in the 1-L reactor at similar agitation rate (Table 4.2). At $500 \mathrm{rpm}$ agitation rate, cell mass was $12.69 \mathrm{~g} / \mathrm{L}$ in the small reactor, whereas cell mass in the large reactor was $48.98 \mathrm{~g} / \mathrm{L}$, which was 3.8 times higher than that in the small one. At $750 \mathrm{rpm}$, cell mass concentration in the large reactor was $138.2 \mathrm{~g} / \mathrm{L}$, and was 4.6 times higher than that in the small reactor. The protein production at $750 \mathrm{rpm}$ showed similar result, with protein concentration in the large reactor 4.6 times greater than that in the small reactor. The dissolved oxygen decreased throughout the fermentation and also showed the better oxygen transfer efficiency in the large reactor.

The oxygen transfer efficiency difference between the two reactors could be explained by their different reactor design. Both reactors are equipped with the disc turbine type of agitator. The disc turbine consists of a disc with a series of rectangular blades set in a vertical plane. For the 1.6-L reactor there are six blades on the disc turbine, while the 1-L reactor has only four of them. The agitator with more blades attached on it may cause a better bubble break up. In addition, four baffles were installed into the large reactor, and these baffles were not present in the small reactor. Baffles in agitated vessels prevent a vortex and improve aeration efficiency. The swirl and vortex are normally undesirable in the aerobic fermentation. Therefore, the large reactor equipped with baffles is more efficient in the dispersion of dissolved oxygen. 


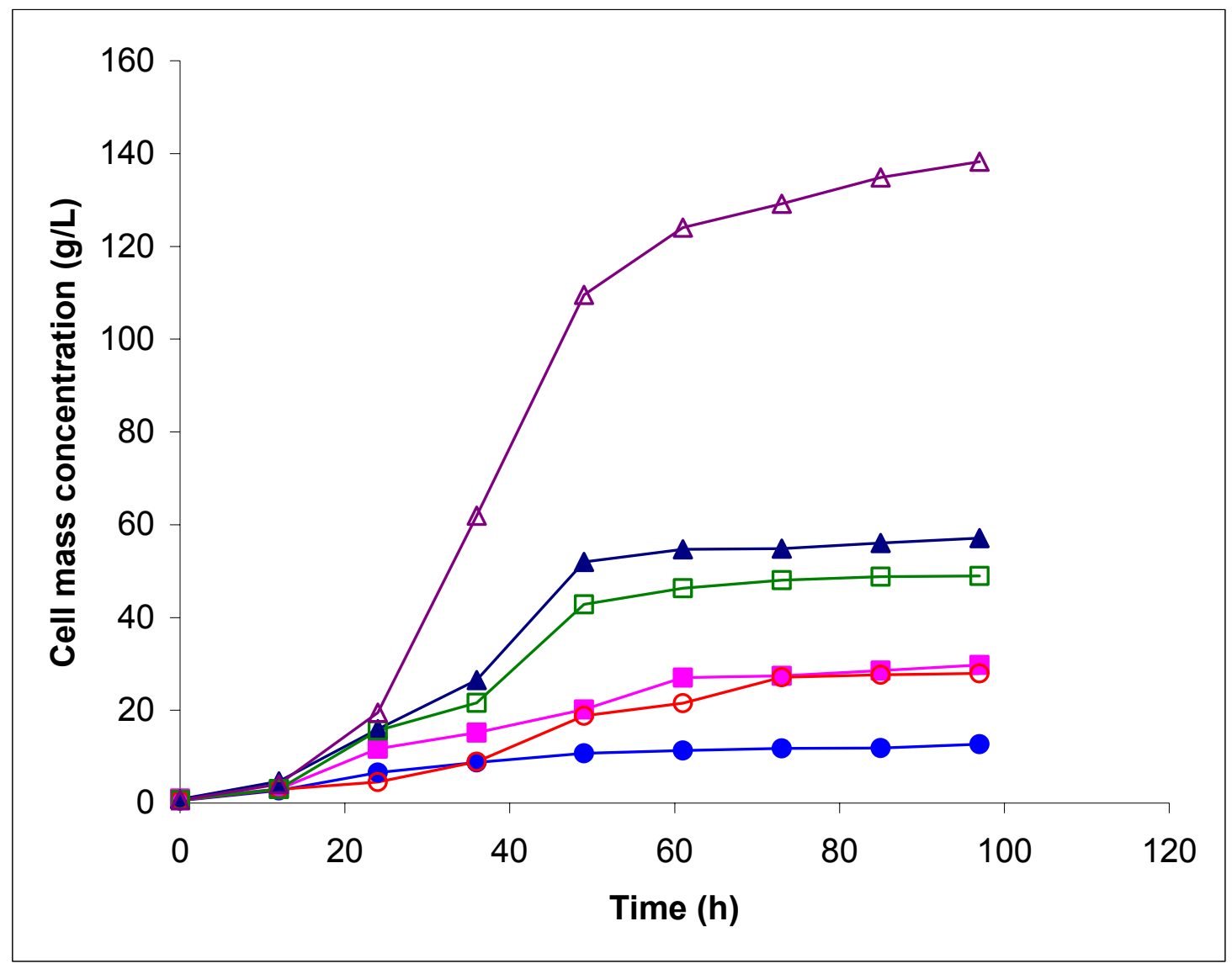

Figure 4.15 Comparison of cell growth pattern between two reactors

$750 \mathrm{ml}$ fermentaion at $500 \mathrm{rpm}(\bullet)$

$750 \mathrm{ml}$ fermentaion at $750 \mathrm{rpm}(\square)$

$750 \mathrm{ml}$ fermentaion at $1000 \mathrm{rpm}(\boldsymbol{\Delta})$

$1 \mathrm{~L}$ fermentaion at $350 \mathrm{rpm} \mathrm{( \circ )}$

$1 \mathrm{~L}$ fermentaion at $500 \mathrm{rpm}(\square)$

$1 \mathrm{~L}$ fermentaion at $750 \mathrm{rpm}(\triangle)$ 


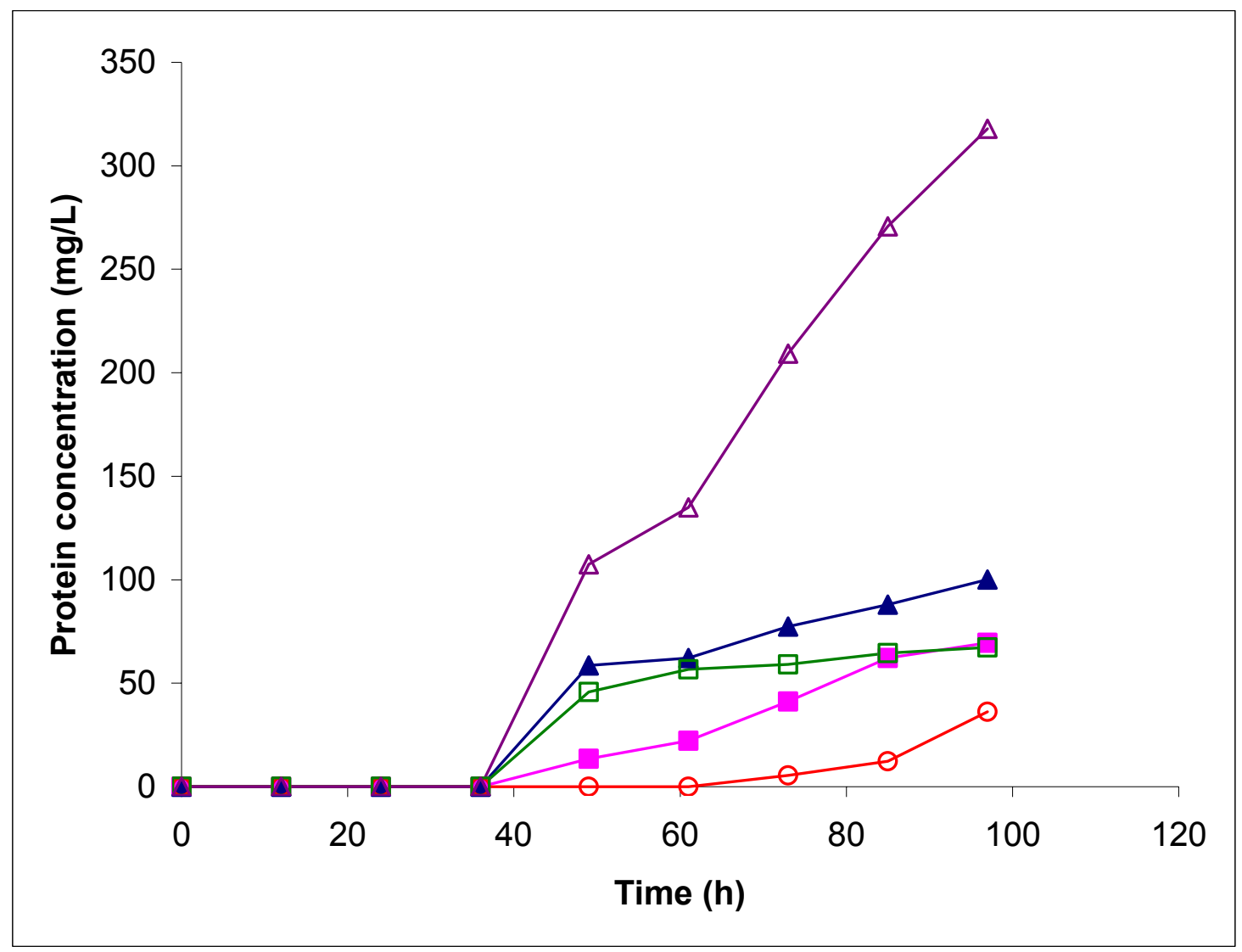

Figure 4.16 Comparison of protein formation pattern between two reactors

$750 \mathrm{ml}$ fermentaion at $750 \mathrm{rpm}(\square)$

$750 \mathrm{ml}$ fermentaion at $1000 \mathrm{rpm}(\mathbf{\Delta})$

$1 \mathrm{~L}$ fermentaion at $350 \mathrm{rpm} \mathrm{(O)}$

$1 \mathrm{~L}$ fermentaion at $500 \mathrm{rpm}(\square)$

$1 \mathrm{~L}$ fermentaion at $750 \mathrm{rpm}(\triangle)$ 


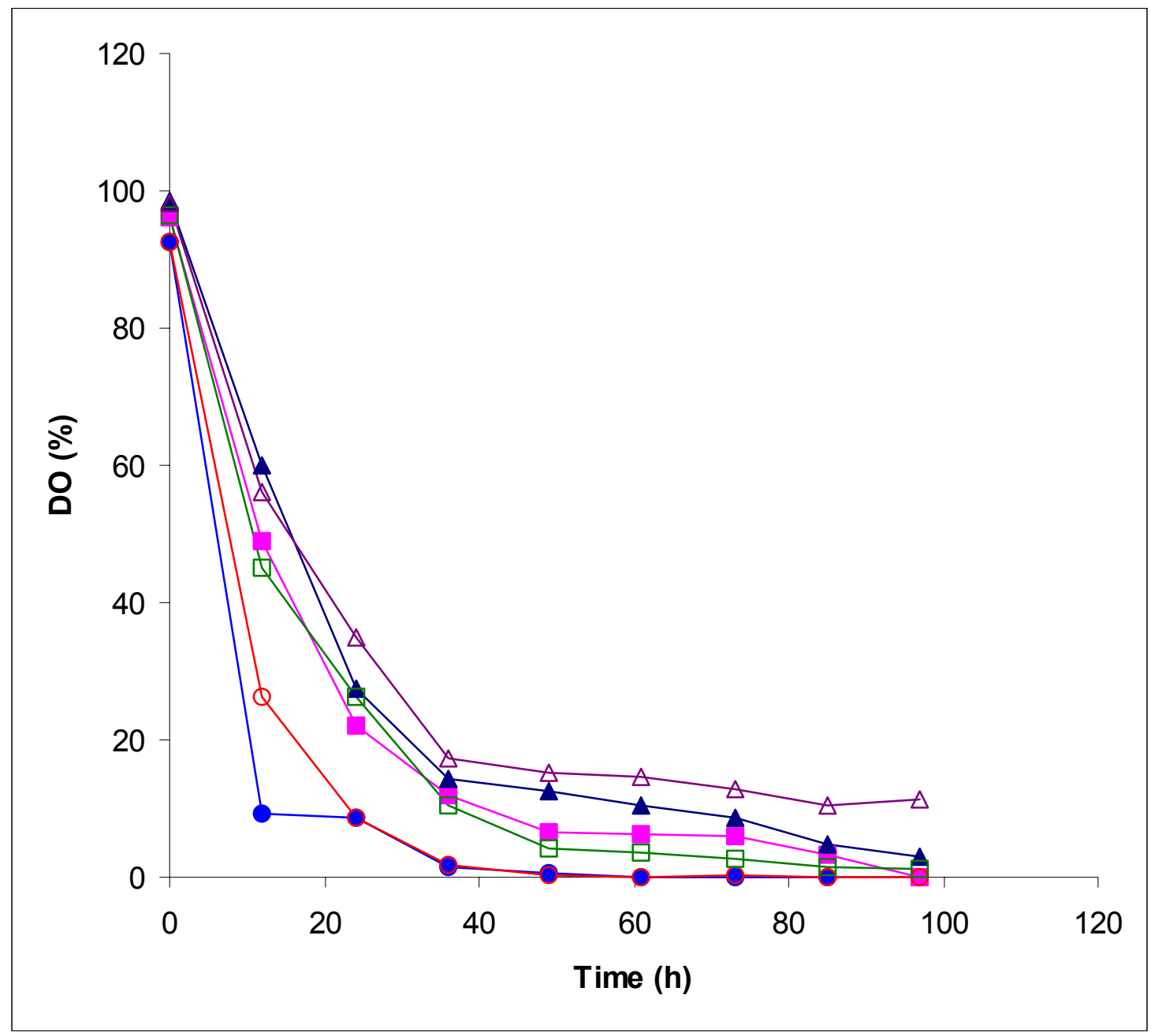

Figure 4.17 Comparison of dissolved oxygen pattern between two reactors

$750 \mathrm{ml}$ fermentaion at $500 \mathrm{rpm}(\bullet)$

$750 \mathrm{ml}$ fermentaion at $750 \mathrm{rpm}(\square)$

$750 \mathrm{ml}$ fermentaion at $1000 \mathrm{rpm}(\boldsymbol{\Delta})$

$1 \mathrm{~L}$ fermentaion at $350 \mathrm{rpm} \mathrm{( \circ )}$

$1 \mathrm{~L}$ fermentaion at $500 \mathrm{rpm}(\square)$

$1 \mathrm{~L}$ fermentaion at $750 \mathrm{rpm}(\triangle)$ 
Table 4.2 Final cell mass concentration, protein concentration, substrate yield, and product yield comparison between two fermenters

\begin{tabular}{cccccc}
\hline $\begin{array}{c}\text { Fermenter } \\
\text { working } \\
\text { Volume }(\mathrm{ml})\end{array}$ & $\begin{array}{c}\text { Agitation } \\
\text { rate }(\mathrm{rpm})\end{array}$ & $\begin{array}{c}\text { Cell mass } \\
\text { concentration } \\
(\mathrm{g} / \mathrm{L})\end{array}$ & $\begin{array}{c}\text { Protein } \\
\text { concentration } \\
(\mathrm{mg} / \mathrm{L})\end{array}$ & $\begin{array}{c}\text { Ys } \\
(\mathrm{g} \text { cell/g } \\
\text { glycerol })\end{array}$ & $\begin{array}{c}\mathrm{Y}_{\mathrm{P}} \\
(\mathrm{mg} \text { protein/g } \\
\text { methanol })\end{array}$ \\
\hline 750 & 500 & 12.69 & - & 0.326 & - \\
750 & 750 & 29.74 & 69.52 & 0.368 & 2.51 \\
750 & 1000 & 57.09 & 100.0 & 0.397 & 2.72 \\
1000 & 350 & 27.95 & 36.29 & 0.334 & 1.57 \\
1000 & 500 & 48.98 & 67.34 & 0.39 & 2.38 \\
1000 & 750 & 138.2 & 317.9 & 0.438 & 5.21 \\
& & & & & \\
\hline
\end{tabular}

\subsubsection{Cell Mass Productivity}

Cell mass productivity patterns in the conventionally sparged system for both the large and small fermenters were demonstrated in Figure 4.18. Poor oxygen transfer could be seen in the small reactor at $500 \mathrm{rpm}$ and $750 \mathrm{rpm}$, as well as in the large reactor at $350 \mathrm{rpm}$, with the productivity curve approximately flat at a very low level and no obvious peak. While the other 
three curves with better oxygen transfer showed more typical growth pattern of $P$. pastoris. Cells were growing at a higher rate before cell mass productivity reached its maximum.

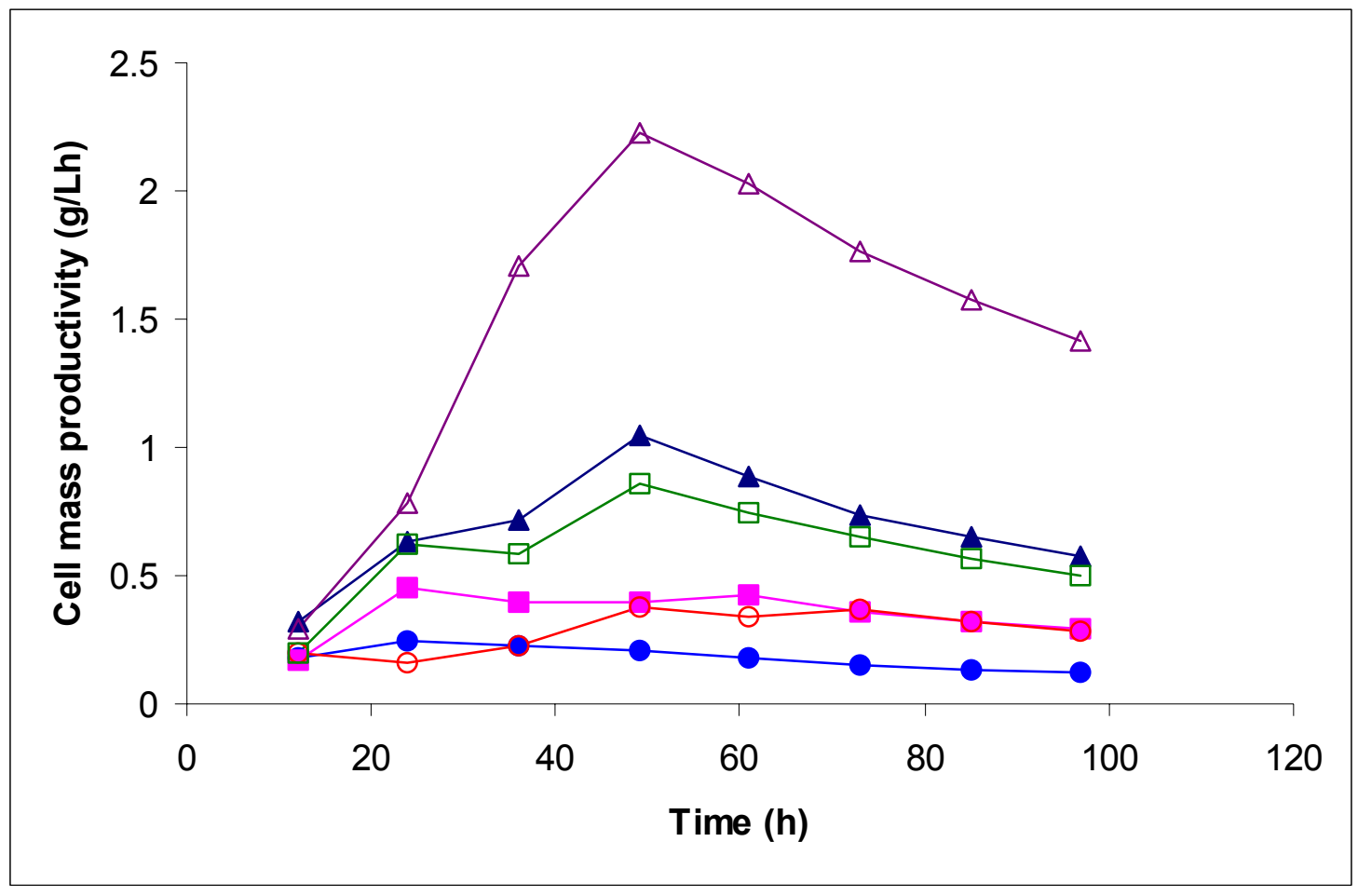

Figure 4.18 Cell mass productivity in conventional fermentation

$$
\begin{aligned}
& 750 \mathrm{ml} \text { fermentaion at } 500 \mathrm{rpm}(\bullet) \\
& 750 \mathrm{ml} \text { fermentaion at } 750 \mathrm{rpm}(\square) \\
& 750 \mathrm{ml} \text { fermentaion at } 1000 \mathrm{rpm}(\mathbf{\Delta}) \\
& 1 \mathrm{~L} \text { fermentaion at } 350 \mathrm{rpm}(\odot) \\
& 1 \mathrm{~L} \text { fermentaion at } 500 \mathrm{rpm}(\square) \\
& 1 \mathrm{~L} \text { fermentaion at } 750 \mathrm{rpm}(\triangle)
\end{aligned}
$$

Cell mass productivities in the $750 \mathrm{ml}$ fermentations showed maximum values of $0.23 \mathrm{~g} /$ $(\mathrm{L} \cdot \mathrm{h}), 0.43 \mathrm{~g} /(\mathrm{L} \cdot \mathrm{h})$, and $1.0 \mathrm{~g} /(\mathrm{L} \cdot \mathrm{h})$ at agitation speed of $500 \mathrm{rpm}, 750 \mathrm{rpm}$ and $1000 \mathrm{rpm}$ respectively. Cell mass productivities in the $1 \mathrm{~L}$ fermentations had maximum values of $0.37 \mathrm{~g}$ / $(\mathrm{L} \cdot \mathrm{h}), 0.86 \mathrm{~g} /(\mathrm{L} \cdot \mathrm{h})$, and $2.2 \mathrm{~g} /(\mathrm{L} \cdot \mathrm{h})$ at the agitation speed of $350 \mathrm{rpm}, 500 \mathrm{rpm}$ and $750 \mathrm{rpm}$ 
respectively. Thus, cell productivity pattern showed considerable improvement when oxygen delivery to the microorganisms was increased by increaseing agitation rate. The comparison of cell productivity between the two reactors also demonstrated a higher efficiency of oxygen transfer in the large reactor than in the small one.

\subsubsection{Protein Productivity}

Protein productivity patterns in the conventionally sparged system for both the large and small reactors are shown in Figure 4.19. The protein productivity curve at $750 \mathrm{rpm}$ in the small reactor was similar to the curve at $350 \mathrm{rpm}$ and $750 \mathrm{rpm}$ in the large reactor. The unusual protein productivity pattern at $500 \mathrm{rpm}$ in the large reactor described in section 4.4 .2 was also observed in the small reactor at $1000 \mathrm{rpm}$. The cell growth and protein production at $500 \mathrm{rpm}$ in the large reactor and at $1000 \mathrm{rpm}$ in the small reactor were coincidently similar, with the dissolved oxygen profile below the critical value but above zero. Thus, the unusual protein productivity pattern may be explained by the fact that the dissolved oxygen level dropped below the critical value but not completely to zero, thus the protein secretion process was somewhat affected.

The protein maximum productivities in the $750 \mathrm{ml}$ fermentation were of $0.73 \mathrm{mg} /(\mathrm{L} \cdot \mathrm{h})$ and $1.2 \mathrm{mg} /(\mathrm{L} \cdot \mathrm{h})$ at $750 \mathrm{rpm}$ and $1000 \mathrm{rpm}$. Productivities in the $1 \mathrm{~L}$ fermentation reached their maximal values of $0.37 \mathrm{mg} /(\mathrm{L} \cdot \mathrm{h}), 0.94 \mathrm{mg} /(\mathrm{L} \bullet \mathrm{h})$, and $3.3 \mathrm{mg} /(\mathrm{L} \cdot \mathrm{h})$ at $350 \mathrm{rpm}, 500 \mathrm{rpm}$, and $750 \mathrm{rpm}$, respectively. Similarly protein production was associated with cell growth, thus, protein productivity patterns also showed considerable improvement in the oxygen delivery into the microorganisms by increased agitation rate. The comparison of protein productivity between two reactors also showed more efficient oxygen transfer in the large reactor than in the small one, resulting in a better protein production. 


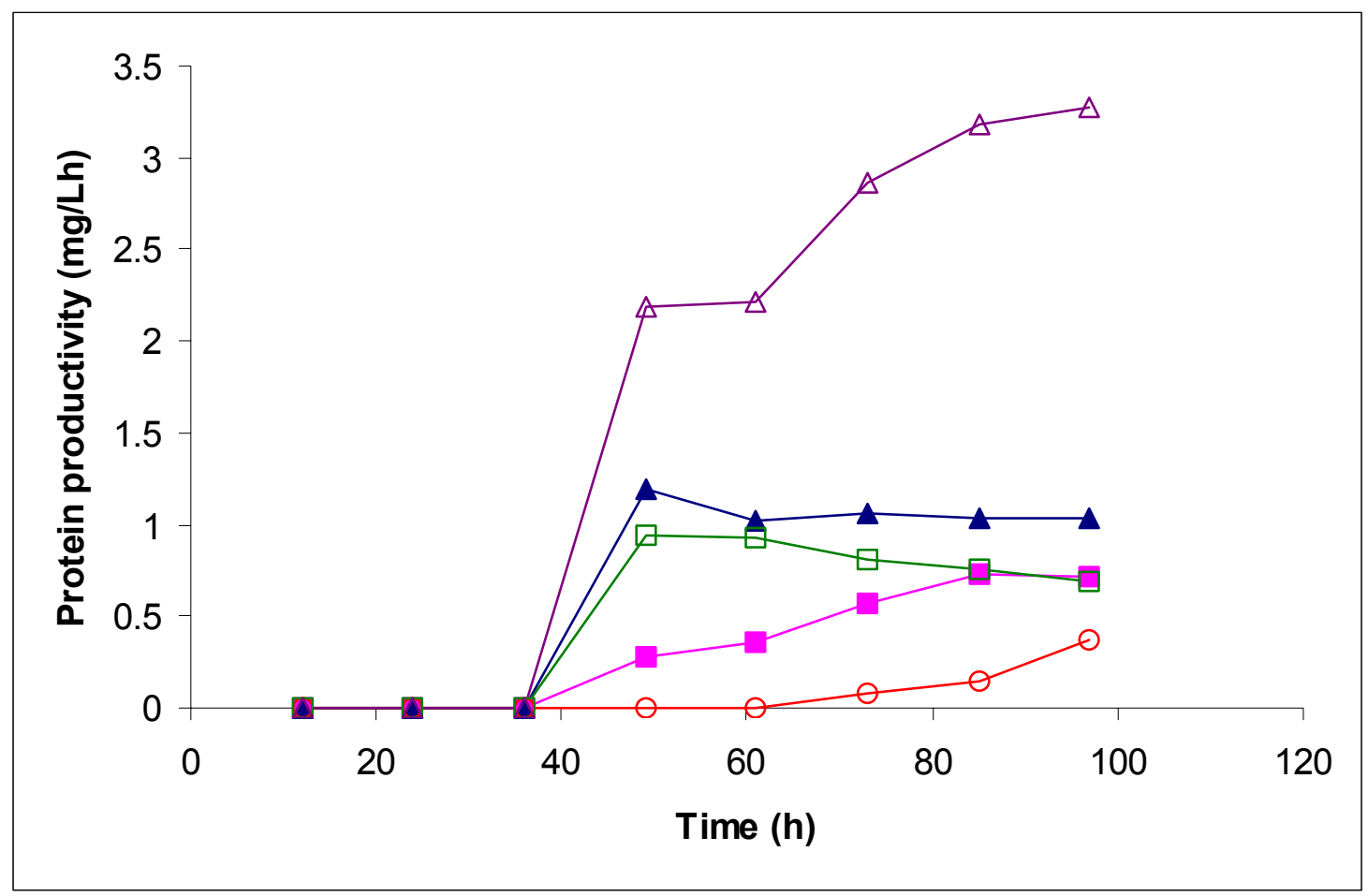

Figure 4.19 Protein productivity in conventional fermentation

$750 \mathrm{ml}$ fermentaion at $750 \mathrm{rpm}(\square)$

$750 \mathrm{ml}$ fermentaion at $1000 \mathrm{rpm}(\mathbf{\Delta})$

$1 \mathrm{~L}$ fermentaion at $350 \mathrm{rpm} \mathrm{(}()^{2}$

$1 \mathrm{~L}$ fermentaion at $500 \mathrm{rpm}(\square)$

$1 \mathrm{~L}$ fermentaion at $750 \mathrm{rpm}(\triangle)$

\subsection{Volumetric Oxygen Transfer Coefficient $k_{L} a$}

As discussed in section 3.4.3 the volumetric oxygen transfer coefficients were calculated in accordance to the yield coefficient method. In the first 36 hours of fermentation, the cells grew on glycerol, and no heterologous protein was produced at this stage. The Mateles (Mateles 1971) 
correlation to determine the oxygen yield was originally designed for cell protein production only, which agreed with the situation in this study.

To determine the $k_{L} a$ value the specific growth rate $\mu$ in equation (3-1) needs to be known. Here for the fed-batch fermentation, the rate of change in cell concentration is

$$
\begin{aligned}
\frac{d X}{d t} & =\left(\mu_{\text {net }}-\mathrm{D}\right) X \\
\text { Thus, } \quad \mu_{\text {net }} & =\frac{1}{X} \frac{d X}{d t}+\mathrm{D}
\end{aligned}
$$

$\mathrm{D}\left(\mathrm{h}^{-1}\right)$ is the dilution rate of the system and equal to substrate feeding rate $\mathrm{F}(\mathrm{ml} / \mathrm{h})$ divided by the liquid volume in the reactor $\mathrm{V}(\mathrm{ml})$, which was $0.0195 \mathrm{~h}^{-1}$ at $36 \mathrm{~h}$ of fermentation in the study. $X$ was the cell mass concentration at $36 \mathrm{~h} . \frac{d X}{d t}$ was the slope of the cell mass concentration curve at $36 \mathrm{~h}$. The calculations of $Y_{O}$ and $Y_{S}$ were described in 3.4.3. The solubility of oxygen in pure water at $30{ }^{\circ} \mathrm{C}$ was regarded as the $C^{*}$ in equation (3-1). Using this value to calculate the $k_{L} a$ may not be precise but still good enough comparison between different systems to see the oxygen transfer efficiency. Therefore, the volumetric oxygen transfer coefficient $k_{L} a$ could be calculated for each run.

\subsubsection{Comparison of $k_{L} a$ value between Two Reactors}

The volumetric mass-transfer coefficient is used as a measure of aeration capacity of a fermenter, the larger the $k_{L} a$, the higher the aeration capacity of the system. Figure 4.20 demonstrated the $k_{L} a$ values at different agitation rates in two different reactors. It can be easily seen that the aeration capacity of the conventionally sparged system was proportional to the agitation rate conducted. The higher the agitation speed, the better the oxygen transfer efficiency. Thus, the agitation rate is the main factor which affected the aerobic fermentation in the conventionally sparged system.

The comparison of achieved $k_{L} a$ in different reactors also showed better oxygen transfer in the $1.6 \mathrm{~L}$ fermenter than the $1 \mathrm{~L}$ fermenter. At the same agitation speed of $500 \mathrm{rpm}$, the $k_{L} a$ of 
the large fermenter was 2.0 times greater than that of the small fermenter. At the agitation rate of $750 \mathrm{rpm}$, the $k_{L} a$ of the large fermenter was 3.2 times greater than that of the small one. The structure difference between the large and small fermenter described previously in 4.6 .4 caused the pronouncedly different volumetric oxygen transfer coefficient, therefore the pronouncedly different aeration capacities between the two different reactors.

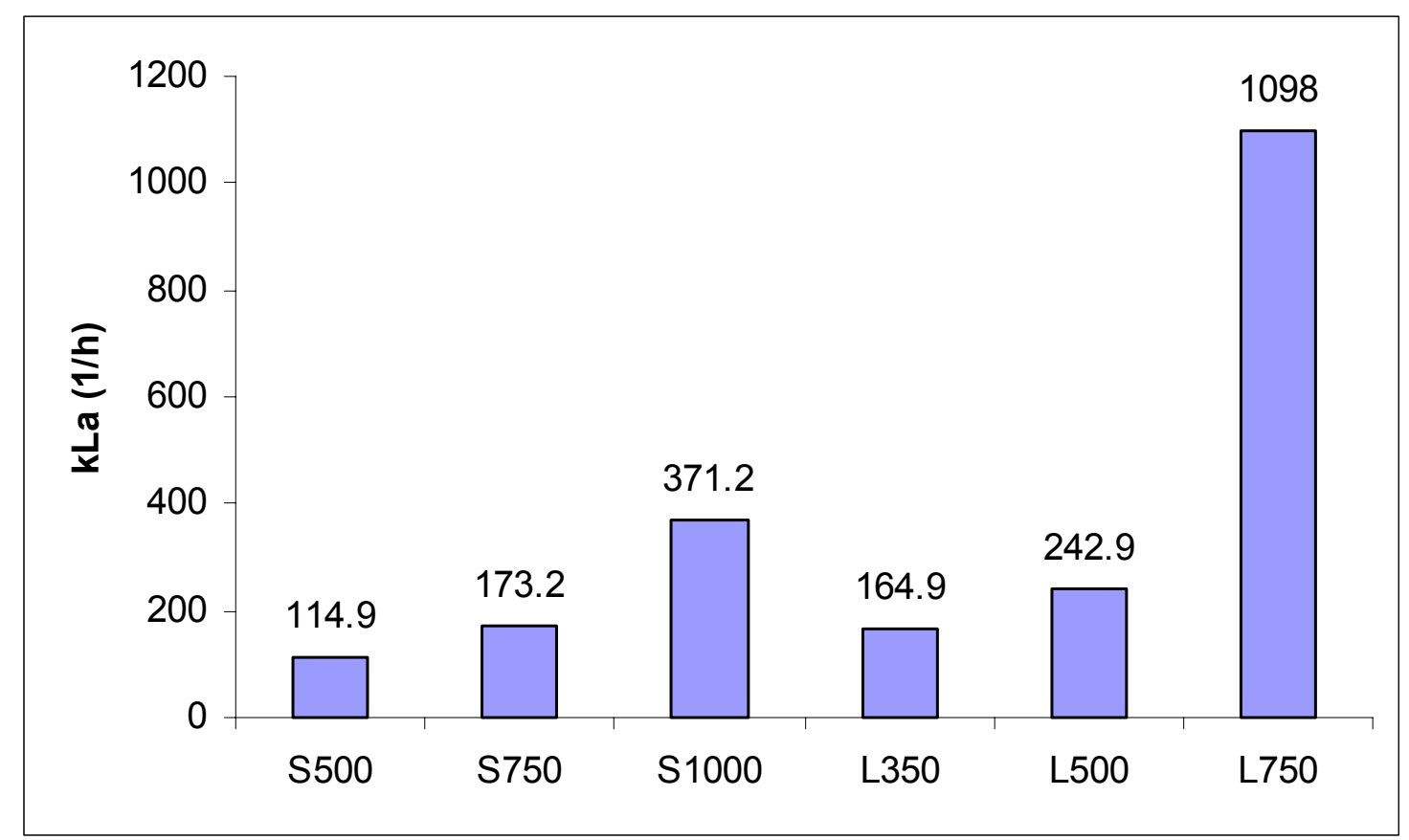

Figure 4.20 Comparison of the $k_{L} a$ value between two reactors

$$
\begin{aligned}
& 500 \mathrm{rpm} \text { in } 1 \mathrm{~L} \text { reactor }(\mathrm{S} 500) \\
& 750 \mathrm{rpm} \text { in } 1 \mathrm{~L} \text { reactor }(\mathrm{S} 750) \\
& 1000 \mathrm{rpm} \text { in } 1 \mathrm{~L} \text { reactor }(\mathrm{S} 1000) \\
& 350 \mathrm{rpm} \text { in } 1.6 \mathrm{~L} \text { reactor }(\mathrm{L} 350) \\
& 500 \mathrm{rpm} \text { in } 1.6 \mathrm{~L} \text { reactor }(\mathrm{L} 500) \\
& 750 \mathrm{rpm} \text { in } 1.6 \mathrm{~L} \text { reactor }(\mathrm{L} 750)
\end{aligned}
$$




\subsubsection{Comparison of $k_{L} a$ value between MBD and conventional systems}

The volumetric oxygen transfer coefficient $k_{L} a$ values at various agitation rates in both conventionally and MBD sparged systems were compared in Figure 4.21. By comparison, the improvement of oxygen transfer in MBD sparged fermentation

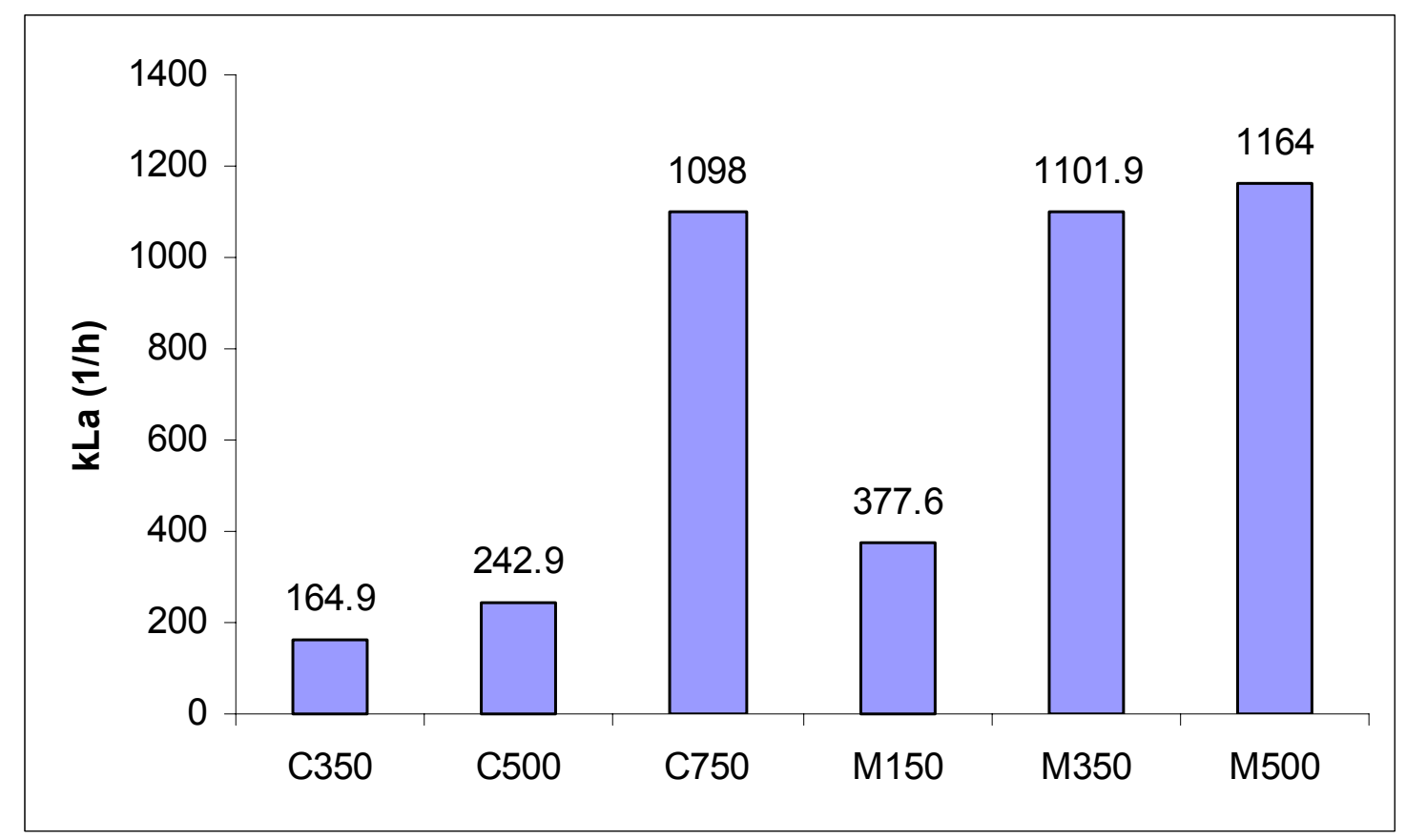

Figure 4.21 Comparison of $k_{L} a$ value between MBD and conventional systems

$350 \mathrm{rpm}$ conventional (C350)

$500 \mathrm{rpm}$ conventional (C500)

750 rpm conventional (C750)

$150 \mathrm{rpm}$ MBD (M150)

$350 \mathrm{rpm}$ MBD (M350)

$500 \mathrm{rpm}$ MBD (M500) 
could be clearly seen. The $k_{L} a$ values in the MBD sparged fermentation at $350 \mathrm{rpm}$ and $500 \mathrm{rpm}$ were not pronouncedly different, and were also not pronouncedly different from the $k_{L} a$ value in the conventionally sparged fermentation at high agitation rate of $750 \mathrm{rpm}$. Thus, once the agitation speed reached $350 \mathrm{rpm}$, further increasing the agitation could not bring further improvement of oxygen transfer in the MBD system.

Low agitation of $150 \mathrm{rpm}$ MBD fermentation also demonstrated that the MBD system had a much better aeration capacity than the conventional one. The $k_{L} a$ value of the MBD sparged fermentation at a relatively low agitation of $150 \mathrm{rpm}$ was even higher than the $k_{L} a$ value of conventional fermentation at a much higher agitation of $500 \mathrm{rpm}$. Also the $k_{L} a$ of MBD fermentation at $350 \mathrm{rpm}$ was similar to the $k_{L} a$ of air fermentation at relatively high agitation of $750 \mathrm{rpm}$. Therefore, the high oxygen transfer efficiency of the MBD sparging system could point to a possible use of MBD as a viable oxygen source for traditional aerobic fermentation.

\subsection{Protein degradation}

The goal of the fed-batch fermentation of P. pastoris is to produce recombinant human serum albumin. The protein stability was tested using SDS-PAGE to assess whether there was any degraded fragment. Different stages of fermentation broth samples in both MBD system and conventional system were selected to run the SDS-PAGE. The result of SDS-PAGE followed by the silver staining procedure was shown in Figure 4.23.

Compared to the standard protein band, it could be seen that the main band in the sample culture broth was rHSA with a molecular weight of $66.5 \mathrm{kD}$. This observation is in agreement with that $P$. pastoris secretes very low levels of native proteins, and thus, the secreted protein comprises the vast majority of the total protein in the medium reported by Barr et al. (1992). With the fermentation carried on, some degraded band appeared around the molecular weight of $45 \mathrm{kD}$, probably due to the appearance of the protease activity in the culture broth. The degradation of rHSA can also be caused by the high shear rate in the MBD generator. If so, a membrane filter with suitable molecular weight cutoff can be incorporated between the recycle pump and the MBD generator to keep the protein from going into the MBD generator. If the degradation was caused by the high shear of the MBD generator, the degradation band would have appeared early during the fermentation. However, the SDS-PAGE results showed that the 
degradation pattern in MBD and conventional fermentation samples were not much different from each other, showing that the degradation was more likely caused by protease activity appeared during the fermentation than the high shear of the MBD generator.

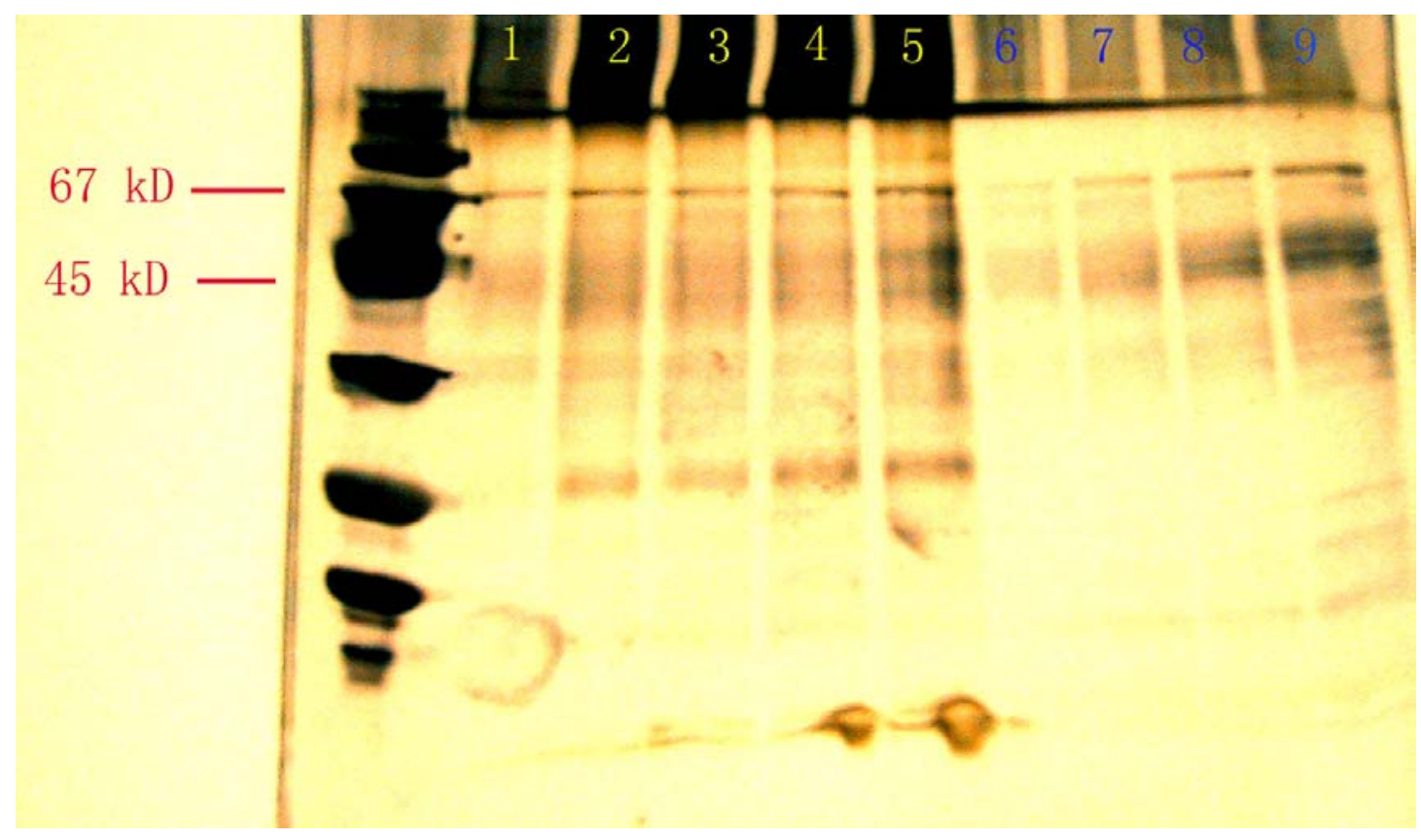

Figure 4.22 SDS-PAGE of different stages of fermentation broth samples in both MBD and conventional systems (1-5, MBD system. 6-9, conventional system) 


\section{CHAPTER 5}

\section{CONCLUSIONS AND RECOMMENDATIONS}

Conventionally sparged fermentation results showed that increasing agitation speed resulted in higher oxygen transfer in the system, but more power need to be consumed, and thus, operating cost would be correspondingly higher. In this study, microbubble dispersion (MBD) achieved similar oxygen transfer at a relatively low agitation speed. In the conventional system, cell mass concentrations after $97 \mathrm{~h}$ were $27.95 \mathrm{~g} / \mathrm{L}, 48.98 \mathrm{~g} / \mathrm{L}$, and $138.2 \mathrm{~g} / \mathrm{L}$ for $350 \mathrm{rpm}$, $500 \mathrm{rpm}$, and $750 \mathrm{rpm}$ respectively. While cell concentration were $52.8 \mathrm{~g} / \mathrm{L}, 129.9 \mathrm{~g} / \mathrm{L}$, and $137.8 \mathrm{~g} / \mathrm{L}$ for $150 \mathrm{rpm}, 350 \mathrm{rpm}$, and $500 \mathrm{rpm}$ MBD fermentation. The biomass yields on glycerol $Y_{S}$ (g cell / g glycerol), which increased with the increasing agitation, were 0.334, 0.390, 0.438 at $350 \mathrm{rpm}, 500 \mathrm{rpm}$, and $750 \mathrm{rpm}$, respectively. While in MBD system $Y_{S}$ were 0.405 , 0.431 , and 0.45 at $150 \mathrm{rpm}, 350 \mathrm{rpm}$, and $500 \mathrm{rpm}$, respectively. Cell mass productivity in conventional system also increased with increased agitation, with the maximum value of $0.37 \mathrm{~g} /$ $(\mathrm{L} \cdot \mathrm{h}), 0.86 \mathrm{~g} /(\mathrm{L} \cdot \mathrm{h})$, and $2.2 \mathrm{~g} /(\mathrm{L} \cdot \mathrm{h})$ at $350 \mathrm{rpm}, 500 \mathrm{rpm}$, and $750 \mathrm{rpm}$, respectively. For the MBD system, maximum cell mass productivity in $150 \mathrm{rpm}$ was $0.92 \mathrm{~g} /(\mathrm{L} \cdot \mathrm{h})$, maximum values at $350 \mathrm{rpm}$ and $500 \mathrm{rpm}$ were both $2.0 \mathrm{~g} /(\mathrm{L} \bullet \mathrm{h})$. It could be clearly seen that cell growth pattern attained at low agitation rate of $350 \mathrm{rpm}$ using MBD sparging was similar to that at high agitation rate of $750 \mathrm{rpm}$ using conventional sparging.

Protein concentrations after $97 \mathrm{~h}$ were $36.29 \mathrm{mg} / \mathrm{L}, 67.34 \mathrm{mg} / \mathrm{L}$, and $317.9 \mathrm{mg} / \mathrm{L}$ in conventional $350 \mathrm{rpm}, 500 \mathrm{rpm}, 750 \mathrm{rpm}$ fermentation, respectively. While for the MBD system, protein concentrations were $95.74 \mathrm{mg} / \mathrm{L}, 267.3 \mathrm{mg} / \mathrm{L}$, and $301.2 \mathrm{mg} / \mathrm{L}$ at $150 \mathrm{rpm}, 350 \mathrm{rpm}$, and $500 \mathrm{rpm}$, respectively. Maximum protein productivities in conventional $350 \mathrm{rpm}, 500 \mathrm{rpm}$, and $750 \mathrm{rpm}$ were $0.37 \mathrm{mg} /(\mathrm{L} \bullet \mathrm{h}), 0.94 \mathrm{mg} /(\mathrm{L} \bullet \mathrm{h})$, and $3.3 \mathrm{mg} /(\mathrm{L} \bullet \mathrm{h})$, respectively. Protein productivities reached maximum value of $1.1 \mathrm{mg} /(\mathrm{L} \cdot \mathrm{h}), 2.8 \mathrm{mg} /(\mathrm{L} \cdot \mathrm{h})$, and $3.1 \mathrm{mg} /(\mathrm{L} \bullet \mathrm{h})$ for $150 \mathrm{rpm}, 350 \mathrm{rpm}$, and $500 \mathrm{rpm}$ MBD fermentation, respectively. The protein yields on methanol $Y p$ (mg protein / g methanol) were 1.57, 2.38, and 5.21 at $350 \mathrm{rpm}, 500 \mathrm{rpm}$, and $750 \mathrm{rpm}$, respectively in the conventional system, and for the MBD system 2.49, 5.02, and 5.15 in 150 $\mathrm{rpm}, 350 \mathrm{rpm}$, and $500 \mathrm{rpm}$ respectively. Therefore, protein production also showed that low 
agitation at $350 \mathrm{rpm}$ in MBD system achieved similar fermentation effectiveness as high agitation of $750 \mathrm{rpm}$ in conventionally sparged system.

The benefit of the MBD system could be more clearly seen in the comparison of achieved volumetric oxygen transfer coefficient $k_{L} a$ values between the MBD and conventional systems. The $k_{L} a$ values in conventional system were $164.9 \mathrm{~h}^{-1}, 242.9 \mathrm{~h}^{-1}$, and $1098 \mathrm{~h}^{-1}$ at 350 $\mathrm{rpm}, 500 \mathrm{rpm}$, and $750 \mathrm{rpm}$ respectively. While in the MBD system the $k_{L} a$ values were $377.6 \mathrm{~h}^{-}$ 1, $1011.9 \mathrm{~h}^{-1}$, and $1164 \mathrm{~h}^{-1}$ at $150 \mathrm{rpm}, 350 \mathrm{rpm}$, and $500 \mathrm{rpm}$, respectively. Thus, the difference in $k_{L} a$ values between low agitation at $350 \mathrm{rpm}$ MBD sparging and high agitation at $500 \mathrm{rpm}$ conventional sparging were not pronounced.

Fermentation results in the MBD system at $150 \mathrm{rpm}$ also demonstrated the higher oxygen transfer efficiency of MBD than the conventional system, with both its cell production and protein production slightly better than those in the conventional $500 \mathrm{rpm}$ fermentation. The $k_{L} a$ value in $150 \mathrm{rpm}$ MBD system was also higher than that in the $500 \mathrm{rpm}$ conventional system. Thus, MBD sparging at low agitation speed could achieve the same oxygen transfer as conventionally sparging at much higher agitation.

The goal of the fermentation was to produce the desired protein recombinant human serum albumin (rHSA). Protein degradation was observed during the fermentation run. The shear stress in the MBD generator and peristaltic pumps may denature the protein partly. However, there was no strong evidence showing protein degradation by the MBD unit, according to the SDS-PAGE results of the sample broth in both MBD system and conventional system. If the degradation was caused by MBD, the degraded band should have appeared when the protein started to be produced. While the degradation pattern in the MBD system was very similar to that in the conventional system, the degraded band got darker with the fermentation carried on, which agreed with protease activity during the fermentation reported by Koabyashi et al. (2000).

The fermentation process remained the same in both MBD and conventional system although the agitation speed varied notably. Varied sparging systems as well as varied agitation speeds brought about different aeration capacity in the different fermentation runs. Low oxygen transfer would cause the accumulation of glycerol in the medium due to poor oxygen provision, but the methanol was still added into the system and also accumulated in the medium, which may result in varied metabolism of the microorganisms. Therefore, optimization of the length of the starvation phase was recommended to get the best performance in protein secretion. 
The experiment was first designed as a two way factorial experiment at three agitation level. Because the time consuming fermentation usually cost one week to conduct only one run, long time of fermentation in both conventional and MBD systems caused higher likelihood of mechanical failure, and the time for completing this study was limited, no experimental replication was conducted. Thus, no statistical analysis could be done with the experimental replications. 


\section{REFERENCES}

Aiba, S., Humphrey ,A. E. and Millis, N. 1973. Biochemical Engineering. Academic Press, London.

Banks, G. T. 1979. Scale-up of fermentatin processes. Topics in Enzyme and Fermentation Biotechnology. 3: 170-267.

Barr K. A., Hopkins S. A., and Sreekrishna K. 1992. Protocol for efficient secretion of HSA developed from Pichia pastoris. Pharmaceutical Engineering. 12(2): 48-51.

Bartholomew, W. H. 1960. Scale-up of submerged fermentations. Adv. App. Micro. 2: 289 -300.

Bell, G. H and Gallo, M. 1971. Effect of impurities on oxygen transfer. Process Biochem. 6(4): 33-35.

Bredwell, M. D. and Worden, R. M. 1998. Biotechnol. Progress 14: 31-38.

Buckland, B. C., Gbewonyo, K., JAIN, d., Glazomitsky, K., Hunt, G. and Drew, S. W. 1988. Oxygen transfer efficiency of hydrofoil impellers in both 800L and 1900L fermenters. In Proceedings of the 2nd. International Conference on Bioreactor Fluid Dynamics. 1-16.

Chapalkar, P. G., Valsaraj, K. T., and Roy, D. 1994. Sep. Sci. Technol., 28(6): 1287.

Cino, Julia. 1999. High yield protein production from Pichia pastoris yeast. American Biotechnology Laboratory.

Clare, J. J., Romanos, M. A., Rayment, F. B., Rowedder, J. E., Smith, M. A., Payne, M. M., Sreekrishna, K. and Henwood, C. A. 1991. Productioin of mouse epidermal growth factor in yeast: high-level secretion using pichia pastoris strains containing multiple gene copies. Gene 105: 205-212. 
Clare, J.J., Rayment, F. B., Ballantine, S. P., Sreekrishna, K. and Romanos, M. A, 1991. Highlevel expression of tetanus toxin fragment $\mathrm{C}$ in Pichia pastoris strains containing multiple tandem integrations of the gene. Bio/Technology 9: 455-460.

Cooper, C. M., Fernstrom, G. A. and Miller, S. A. 1944. Performance of agitated gas-liquid contacters. Ind. Eng. Chem. 36: 504-509.

Cooney, C. L. 1979. Conversion yields in penicillin production: Theory versus practice. Process Biochem. 14(5): 31-33.

Cregg, J. M., Tschopp, J. F., Stillman, C., Siegel, R., Akong, M., Craig, W. S., Buckholz, R. G., Madden, K. R., Kellaris, P. A., Davis, G. R., Smiley, B. L., Cruze, J., Torregrossa, R., Velicelebi, G. and Thill, G. P, 1987. High-level expression and efficient assembly of hepatitis B surface antigen in the methylotrophic yeast, Pichia pastoris. Bio/Technology 5: 479-485.

Cregg, J. M., Madden, K. R., Barringer, K. J., Thill, G., and Stillman, C. A. 1989. Functional characterization of the two alcohol oxidase genes from the yeast, Pichia pastoris. Mol. Cell. Biol. 9: 1316 - 1323.

Cregg J. M., Vedvick T. S., Raschke W. C., 1993. Recent advances in the expression of foreign genes in Pichia pastoris. Bio-Technology 11: 905-909.

Darlington, W. A, 1964. Aerobic hydrocarbon fermentation - A practical evaluation. Biotech. Bioeng. 6 (2): 241-242.

Digan, M. E., Lair, S. V., Brierley, R. A., Siegel, R. S., Williams, M. E., Ellis, S. B., Kellaris, P. A., Provow, S. A., Craig, W. S., Velicelebi, G., Harpold, M. and Thill, G. P,1989. Continuous production of a novel lysozyme via secretion from the yeast, Pichia pastoris. Bio/Technology 7: 160-164. 
Dijken, J. P. van, and Harder, W, 1974. Optimal conditions for the enrichment and isolation of methanol-assimilating yeasts. J. Gen. Microbiol. 84: 409-411.

Doran, P. M. 1995. Bioprocess Engineering Principles. San Diego: Academic Press.

Ellis, S.B., Brust, P. F., Koutz, P. J., Waters, A. F., Harpold, M. M., and Gingeras, T. R. 1985. Isolation of alcohol oxidase and two other methanol regulatable genes from the yeast, Pichia pastoris. Mol. Cell. Biol. 5: 1111-1121.

Faber KN, Harder W, Ab G, Veenhuis M, 1995. Methylotrophic yeasts as factories for the production of foreign proteins. Yeast (11): 1331-1344.

Fleer R., Yeh P., Amellal N., Maruy I., Fournier A., Bacchetta F., Baduel P., Jung G., Becquart J., Fukuhara H. and Mayaux J. F. Stable Multicopy vectors for high-level secretion of recombinant human serum albumin by Kluyveromyces yeasts. Bio/Technology. 9: 968 - 975.

Gellissen G. 2000. Heterologous protein production in methylotrophic yeasts Appl. microbial. Biotechnol. 54: 741-750.

Hensirisak, P. 1997. Scale-up the use of a microbubble dispersion to increase oxygen transfer in aerobic fermentation of Baker's yeast. M.S. thesis. Virginia Polytechnic Institute and State University.

Hitzeman, R. A., Hagie, F. E., Levine, H. L., Goeddel, D.V., Ammerer, G. and Hall, B.D. 1981. Expression of a human gene for interferon in yeast. Nature 293: 717-722.

Hodgkins, M.A. Sudbery, P.E., Kerry-Williams, S. 1990. Secretion of human serum albumin from Hansenula polymorpha. 15 th international conference on yeast genetics and molecular biology. S435. 
Itakura, K., Hirose, T., Crea, R., 1977. Expression in Escherichia coli of a chemically synthesized gene for the hormone somatostatin. Science 198: 1056-1063

Jauregi, P., Gilmour, S. Varley, J. 1997. Characterisation of colloidal gas aphrons for subsequent use for protein recovery. The Chemical Engineering Journal. 65: 1-11.

Johnson, M. J, 1964. Utilization of hydrocarbons by microorganisms. Chem. Ind. 36: 1532-1537.

Kaoru Kobayashi, Shisnobu Kuwae, Tomoshi Ohya, Toyoo Ohda, Masao Ohyama, Hideyuki Ohi, Kenji Tomomitsu, and Takao Ohmura, 2000. High-level expression of recombinant human serum albumin from the methylotrophic yeast pichia pastoris with minimal protease production and activation. Journal of Bioscience and Bioengineering 89: No1: 55-61.

Kaster, J.A. 1988. Increased oxygen transfer in a yeast fermentation using microbubble dispersion. M.S. Virginia Polytechnic Institute and State University.

Kaster, J. A., D. J. Michelsen, and W. H. Velander. 1990. Increased oxygen transfer in a yeast fermentation using a microbubble dispersion. Appl. Biochem. Biotechnol. 24/25: 469-484.

Kaster, J. A., Michelsen, D. L., and Velander, W. H. 1990. Appl. Biochem. Biotechnol. (24/25): 469-484.

Klaas N. F., Wim H., Geert A. B. and Marten V., 1995. Methylotrophic yeasts as factories for the production of foreign proteins. Yeast 11: 1331-1344.

Klaus Wolf, 1995. Nonconventional Yeasts in Biotechnology. Springer 203-250.

Koutz, P. J., Davis, G. R., Stillman, C., Barringer, K., Cregg, J. M., and Thill, G. 1989. Structural comparison of the Pichia pastoris alcohol oxidase genes. Yeast. 5: 167-177. 
Mateles, R. I. 1971. Calcultation of the oxygen required for cell production. Biotechnol. Bioeng. 13: 581-582.

Mingetti, P. P., Ruffner, D. E., Kuang, W. J., Dennison, O. E., Hawkins, J. W., Beattie, W. G., and Dugaiczyk, A. 1986. Molecular structure of the human albumin gene is revealed by nucleotide sequence within q11-22 of chromosome 4. J. Biol. Chem. 261: 6747-6757.

Motarjemi, M., and G. J. Jameson. 1978. Mass transfer from very small bubbles-the optimum bubble size for aeration. Chem. Eng. Sci. 33(11): 1415-1423.

Oolman, T.O. and Blanch, H.W. 1986. Chem. ENGIN. Commun. (43): 237-261

Oolman, T.O. and Blanch, H.W, 1983. Bubble coalescence and break-up in fermenters-effect of surfactant, inorganic salts, and non-Newtonian rheology. Abstract of Papers-American Chemical Society.

Parakulsuksatid, P. 2000. Utilization of a microbubble dispersion to increase oxygen transfer in pilot-scale Baker's yeast fermentation unit. M.S. thesis. Virginia Polytechnic Institute and State University.

Peters, T.: Serum albumin, 1985. In Anfinsen, C. B., Edsall, J. T., and Richards, F. M. (ed.), Advances in protein chemistry, vol. 37. Academic Press Inc., San Diego 161-245.

Richard G. Buckholz and Martin A. G. Gleeson, 1991. Yeast systems for the commercial production of heterologous proteins. Bio/Technology 9: 1067-1071.

Righelato, R. C., Trinci, A. P. J., Pirt, S. J. and Peat, A. 1968. Influence of maintenance energy and growth rate on the metabolic activity, morphology and conidiation of Penicillium chrysogenum. J. Gen. Micro. 50(1): 394-412. 
R.Mark Worden and Marshall D. Bredwell, 1998. Mass-Transfer Properties of Microbubbles Biotechno. Prog. 14: 39-46.

Romanos, M. A., Clare, J. J., Beesley, K. M., Rayment, F. B., Ballantine, S. P., Makoff, A. J., Dougan, G., Fairweather, N. F. and Charles, I. G, 1991. Recombinant Bordetella pertussis pertactin (P69) from the yeast Pichia pastoris: high-level production and immunological properties. Vaccine 9: 901-906.

Romanos MA, Scorer CA, Clare JJ, 1992. Foreign gene expression in yeast. Yeast 8: 423-488.

Rosen, M. J. Surfactants and interfacial phenomena, 2nd ed., 1989 John Wiley and Sons: New York.

Sebba, F. 1971. Microfoams-an unexploited colloid system. J. Colloid Interface Sci. 35 (4):643646.

Sebba, F. 1985. An improved generator for micron-size bubbles. Chem. Ind. (London). 4:91-92.

Sebba. 1987. Foams and biliquid foams-aphrons. Wiley, Chichester, Chap. 5.

Sleep D., Belfield G.P., Balance D J., Steven J., Jones S., Evans L. R., Moir P. D. and Goodey A. R. 1991. Saccharomyces cerevisia strains that overexpress heterologous proteins. Bio/Technology. 9:183 - 187.

Sreekrishna, K., Nelles, L., Potenz, R., Cruze, J., Mazzaferro, P., Fish, W., Fuke, M., Holden, K., Phelps, D., Wood, P. and Parker, K, 1989. High-level expression, purification, and characterization of recombinant human tumor necrosis factor synthesized in the methylotrophic yeast Pichia pastoris. Biochemistry 28: 4117-4125. 
Siegel, R. S., Buckholz, R. G., Thill, G. P. and Wondrack, L.M, 1990. Production of epidermal growth factor in methylotrophic yeast cells. International Patent Application, Publication No: WO 90/10697

Srivastava, P., Hahr, O., Buchholz, R., and Worden, R. M. 2000. Biotechnol. Bioeng. 70 (50): $525-532$.

Stanbury, P. F., Whitaker A., and Hall S. J. 1995. Principles of Fermentation Technology. Pergamon 243-272.

Taguchi, H., and A. E. Humphrey. 1966. Dynamic measurement of volumetric oxygen transfer coefficient in fermentation system. J. Ferment. Tech. (Japan). 44:881-889.

Tschopp, J. F., Sverlow, G., Kosson, R., Craig, W. and Grinna, L, 1987. High-level secretion of glycosylated invertase in the methylotrophic yeast, Pichia pastoris. Bio/Technology (5): 1305-1308.

Van't Riet, K. 1979. Review of measuring methods and results in non-viscous gas-liquid mass transfer in stirred vessels. Ind. Eng. Chem. Process Des. Dev. 18(3): 357-360.

Van't Riet, K. and Van Sonsberg. 1992. Foaming, mass transfer and mixing: Interrelations in large scale fermentations. Harnessing Biotechnology for the 21st Century. American Chemical Society, 189-192.

Vedvick, T., Buckholz, R. G., Engel, M., Urcan, M., Kinney, J., Provow, S., Siegel, R. S. and Thill, G. P, 1991. High-levelsecretion of biologically active aprotinin from the yeast pichia pastoris. J. Ind. Microbiol. 7: 197-201.

Veenhuis, M. van Dijken, J.P., and Harder, W. 1983. The significance of peroxisomes in the metabolism of one-carbon compounds in yeasts. Adv. M,crob. Physiol. 24: 1-82. 
Wagner, S. L., Siegel, R. S., Vedvick, T. S., Raschke, W. C. and van Nostrand, W. E, 1992. High-level expression, purification and characterization of the Kunitz-type protease inhibitor domain of protease nexin-2/amyloid $\beta$-protein precursor. Biochem. Biophys. Res. Commun 186: 1138-1145.

Wallman Sonia. 2000. Process controlled fed-batch fermentation of recombinant HAS secreting pichia pastoris. Standard Operating Procedure. http://biotech.tec.nh.us/BT220/SOP/SOPTOC.html

Wang, D. I. C., C. L. Cooney, A. L. Demain, P. Dunnill, A. E. Humphrey, and M. D. $\quad$ Lilly. 1979. Fermentation and Enzyme Technology. New York: John Wiley \& Son.

Wartmann T., Seiber H., Bartelsen O., Gellissen G., Kunze G. High-level production and secretion of recombinant proteins by the dimorphic yeast Arxula adeninivorans. FEMS Yeast Research.2:363 - 369 .

Wegner GH. 1983. Biochemical conversions by yeast fermentation at high cell densities. US Patent 4: 329-414.

Wise, W. S. 1951. The measurement of the aeration of culture media. J. Gen. Micro. (5): 167177.

Xiao Min He, Daniel C. Carter, 1992. Atomic structure and chemistry of human serum albumin. Nature 358: 209-214.

Yoshida, F., Ikeda, A., Imakawa, S., and Miura, Y. 1960. Industrial and Engineering Chemistry 52: 435-438. 


\section{APPENDIX}

1. Specific protein production rate $q_{p}$

The specific protein production rate $q_{p}$ is defined as the protein production rate $\left(\frac{d P}{d t}\right)$ divided by the cell mass concentration $(X)$ :

$$
q_{p}=\frac{1}{X} \frac{d P}{d t}
$$

where $q_{p}=$ specific protein production rate $\left(\mathrm{h}^{-1}\right)$

$P=$ protein concentration $(\mathrm{g} / \mathrm{L})$

$X=$ cell mass concentration $(\mathrm{g} / \mathrm{L})$

$t=$ time (h)

Protein production rate $\frac{d P}{d t}$ can be obtained from the protein production curve, which equals to the slope of the tangent line at each time point $t$.

2. Specific cell growth rate $\mu_{\mathrm{g}}$

The specific cell mass growth rate $\mu_{\mathrm{g}}$ is defined as cell mass production rate $\left(\frac{d X}{d t}\right)$ divided by the cell mass concentration $(X)$ :

$$
\mu_{\mathrm{g}}=\frac{1}{X} \frac{d X}{d t}
$$

where $\mu_{\mathrm{g}}=$ specific growth rate $\left(\mathrm{h}^{-1}\right)$

$$
\begin{aligned}
X & =\text { cell mass concentration }(\mathrm{g} / \mathrm{L}) \\
\mathrm{t} & =\text { time }(\mathrm{h})
\end{aligned}
$$

Cell mass production rate $\frac{d X}{d t}$ can be obtained from the cell mass production curve, which equals to the slope of the tangent line at each time point $t$. 
3. Correlation of $q_{p}$ and $\mu_{\mathrm{g}}$

Equation of $q_{p}$ as a function of $\mu_{\mathrm{g}}$ can be developed to determine the relationship between $q_{p}$ and $\mu_{\mathrm{g}}$

Table A1: Cell mass concentration calibration data.

\begin{tabular}{|c|c|}
\hline OD $(600 \mathrm{~nm})$ & Cell mass concentration $(\mathrm{g} / \mathrm{L})$ \\
\hline 0.141 & 0.0667 \\
\hline 0.316 & 0.2 \\
\hline 0.605 & 0.3333 \\
\hline 0.925 & 0.5333 \\
\hline 1.156 & 0.7333 \\
\hline
\end{tabular}

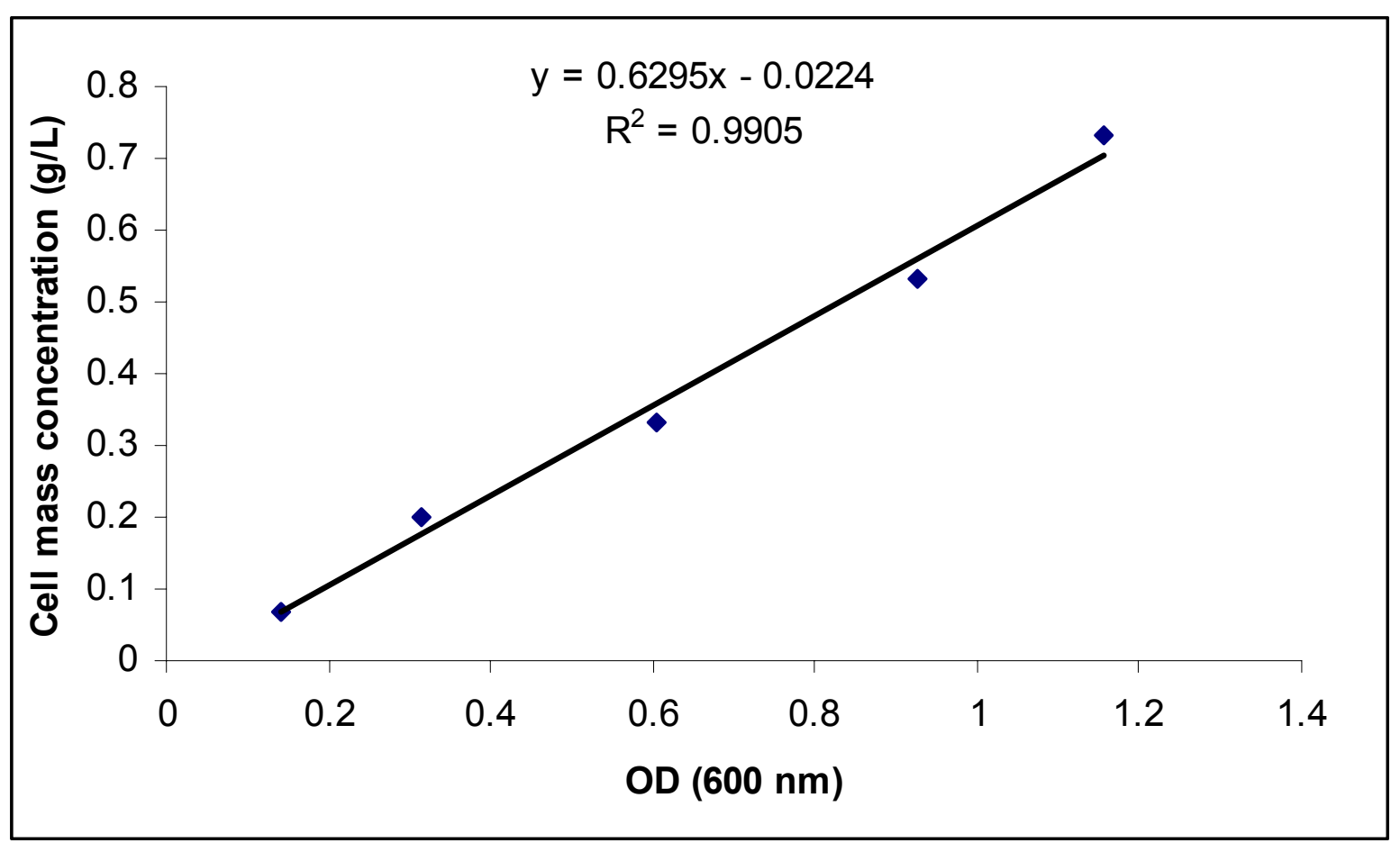

Figure A1. Cell mass concentration calibration curve 
Table A2: Glycerol concentration calibration data.

\begin{tabular}{|c|c|}
\hline Peak area $\left(\times 10^{-5}\right)$ & Glycerol concentration $(\mathrm{g} / \mathrm{L})$ \\
\hline 23.23168 & 1 \\
\hline 68.84227 & 3 \\
\hline 115.24592 & 5 \\
\hline 182.07466 & 8 \\
\hline 225.48012 & 10 \\
\hline
\end{tabular}

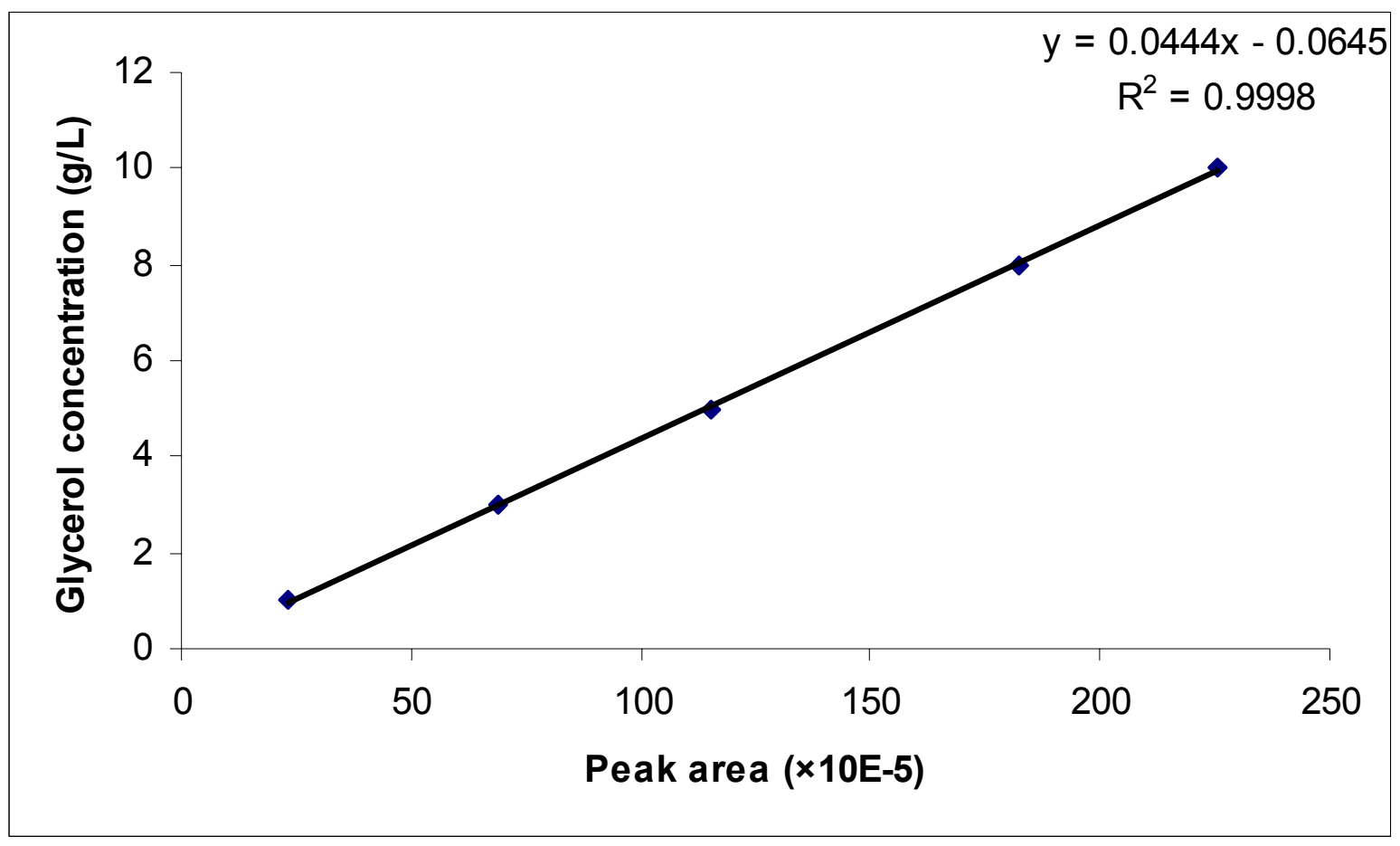

Figure A2. Glycerol concentration calibration curve 
Table A3: Methanol concentration calibration curve

\begin{tabular}{|c|c|}
\hline Peak area $\left(\times 10^{-3}\right)$ & Methanol concentration $(\mathrm{g} / \mathrm{L})$ \\
\hline 163.178 & 5 \\
\hline 328.238 & 10 \\
\hline 474.018 & 15 \\
\hline 623.453 & 20 \\
\hline 779.828 & 25 \\
\hline
\end{tabular}

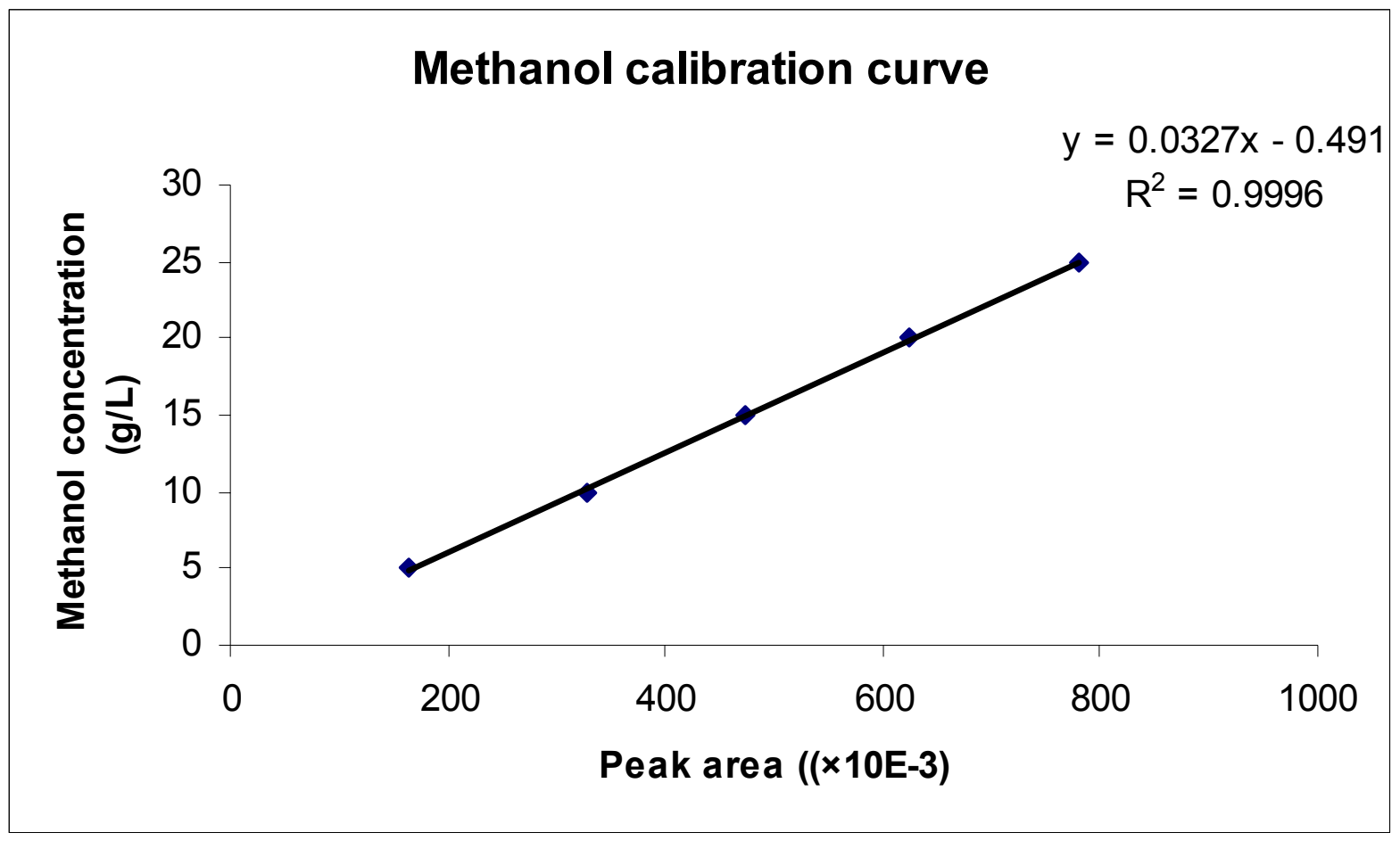

Figure A3. Methanol concentration calibration curve 
Table A4: Protein concentration calibration data.

\begin{tabular}{|c|c|}
\hline Absorbance (700nm) & Protein concentration (mg / L) \\
\hline 0.067 & 10 \\
\hline 0.135 & 20 \\
\hline 0.239 & 30 \\
\hline 0.266 & 40 \\
\hline 0.347 & 50 \\
\hline 0.555 & 100 \\
\hline 0.913 & 200 \\
\hline 1.287 & 300 \\
\hline 1.446 & 400 \\
\hline
\end{tabular}

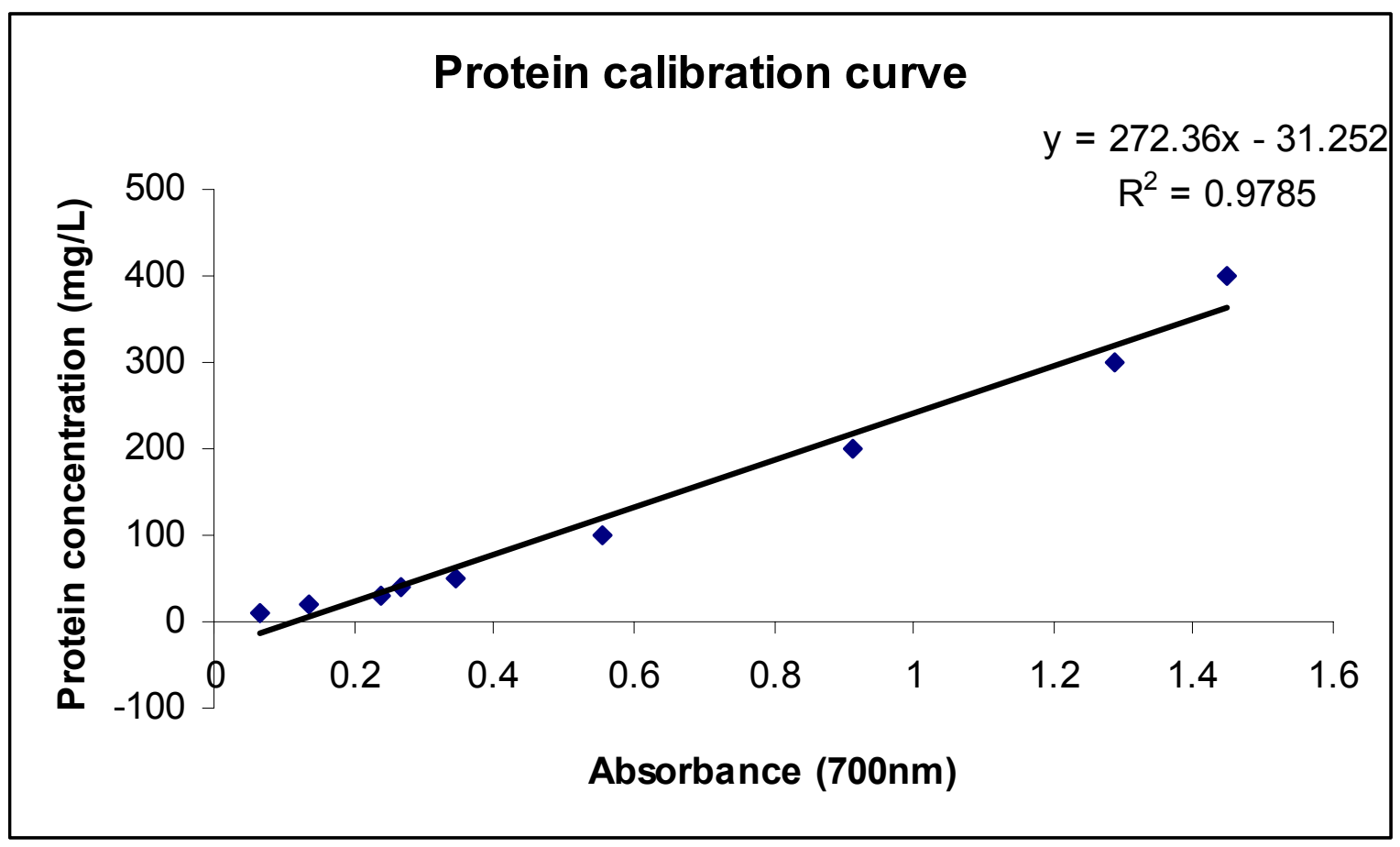

Figure A4. Protein concentration calibration curve 


\section{VITA}

Wei Zhang, was born on November 8, 1975 in Nanjing, China. She got the Bachelor degree of Science in 1998 and Master degree of Science in 2001, both in the major of biochemical engineering in Nanjing University of Chemical Technology. On the fall semester, 2001, she was accepted as a graduate student at Virginia Tech in the Biological Systems Engineering. 